\title{
POLIMORFISMO MOLECULAR EM GERAÇÕES DE BOVINOS DA RAÇA CANCHIM
}

\author{
LUCIANA CORREIA DE ALMEIDA REGITANO \\ Médica Veterinária
}

Orientador: Prof. Dr. João Lúcio de Azevedo

Tese apresentada à Escola Superior de Agricultura "Luiz de Queiroz", da Universidade de São Paulo, para obtenção do título de Doutor em Agronomia, Área de Concentração: Genética e Melhoramento de Plantas.

\author{
PIRACICABA \\ Estado de São Paulo - Brasil \\ Dezembro de 1996.
}


Dados Internacionais de Catalogação na Publicação (CIP)

DIVISÃO DE BIBLIOTECA E DOCUMENTAÇÃO - Campus "Luiz de Queiroz"/USP

Regitano, Luciana Correia de Almeida

Polimorfismo molecular em geraçōes de bovinos da raça Canchim / Luciana

Correia de Almeida Regitano. - - Piracicaba, 1996.

132 p. : il.

Tese (doutorado) -- Escola Superior de Agricultura Luiz de Queiroz, 1997.

Bibliografia.

1. Gado Canchim 2. Genética animal - Melhoramento 3. Marcador molecular 4. Variabilidade genética I. Título.

$\operatorname{CDD} 636.0821$

636.24.2

636.29 


\title{
POLIMORFISMO MOLECULAR EM GERAÇÕES DE BOVINOS DA RAÇA CANCHIM
}

\author{
LUCIANA CORREIA DE ALMEIDA REGITANO
}

Aprovada em: 14.04.1997

Comissão julgadora:

Prof. Dr. João Lúcio de Azevedo

ESALQ/USP

Prof. Dr. Luiz Lehmann Coutinho

ESALQ/USP

Prof. Dr. Irineu Umberto Packer

ESALQ/USP

Dr. Pedro Franklin Barbosa

EMBRAPA/CPPSE

Dr. Emídio Dias Feliciano Silva

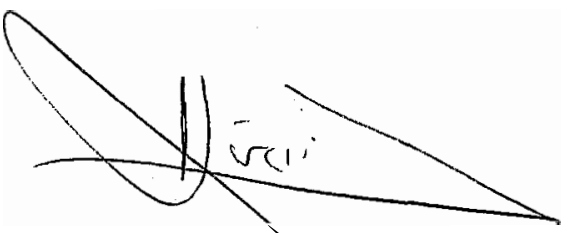

Prof. Dr. João Lúcie de Azevedo

Orientador 
A Amadeu.

pela compauheirisma e compreensäa $e$ as nossos filhos.

André

$e$

Henrigue.

pela alegria que me

proparcionam.

Dedica 


\section{AGRADECIMENTOS}

- Ao Prof. Dr. João Lúcio de Azevedo, pela orientação e amizade;

- Ao Prof. Dr. Luiz Lehmann Coutinho, pela amizade e pela oportunidade de participar do dia a dia de seu laboratório;

- Aos professores Dr. Irineu Umberto Packer e Dr. Roland Vencovsky, pelas sugestões durante a análise dos dados;

- Ao Prof. Dr. Henrique Nunes de Oliveira do departamento de Melhoramento e Nutrição Animal da UNESP - Botucatu, pelo cálculo do coeficiente de endogamia a partir da genealogia;

- Ao Dr. Emídio D. F. Silva, pelo inestimável apoio durante a execução desse projeto;

- Ao Dr. Pedro F. Barbosa, pelo auxílio durante o planejamento e coleta de dados e pelas valiosas discussões;

- Ao Dr. Maurício M. de Alencar, pelas informações sobre o rebanho Canchim;

- Aos professores Dr. Scott K. Davis e Dr. Jeremy F. Taylor da Texas A\&M University, Animal Sciences Department, pela oportunidade de treinamento e pelas informações sobre o projeto de mapeamento do genoma dos bovinos;

- Aos colegas do Laboratório de Biotecnologia, pela alegre convivência e, em especial, às técnicas de nível superior, Maria Antônia e Nirlei, pelo constante apoio;

- Aos professores do Departamento de Genética, pelos ensinamentos recebidos;

- Aos colegas do Centro de Pesquisa de Pecuária do Sudeste - EMBRAPA, pelo apoio e amizade;

- Ao Dr. Carlos Leskiu, do Instituto Agronômico do Paraná, pelo fornecimento de amostras da raça Charolesa;

- Ao Sr. Leonardo Collares Talavera, do Herd Book Collares, pelas informações sobre a raça Charolesa;

- Aos funcionários do Centro de Pesquisa de Pecuária do Sudeste - EMBRAPA, que contribuiram direta ou indiretamente para a execução desse trabalho; 
- Aos amigos e familiares, pelo estímulo e compreensão.

- À Empresa Brasileira de Pesquisa Agropecuária, pela oportunidade de realizar esse curso de Pós-graduação;

- Às centrais de inseminação Genética Avançada, Lagoa da Serra e Pecplan, pela doação de amostras de sêmen;

- Ao CNPq, pela concessão de bolsa de estudos. 


\section{SUMÁRIO}

LISTA DE TABELAS

Página

LISTA DE FIGURAS

LISTA DE FIGURAS

ix

RESUMO

$\mathrm{xi}$

SUMMARY .

xiv

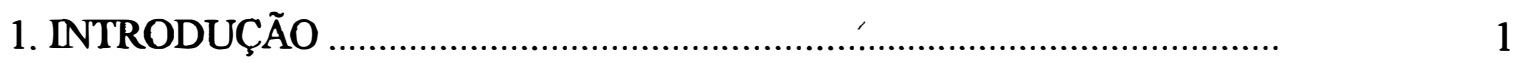

2. REVISÃO DE LITERATURA .........................................................

2.1. Classificação e origem dos bovinos domésticos ...................................... 3

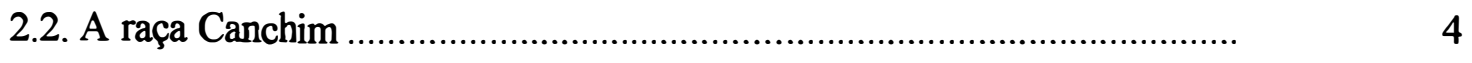

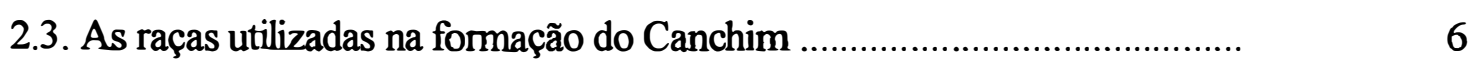

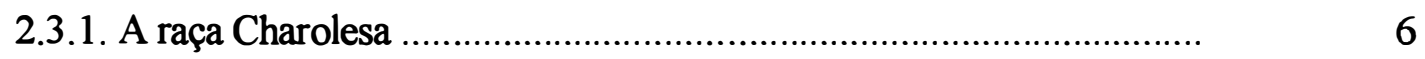

2.3.2. As raças zebuínas ..................................................................

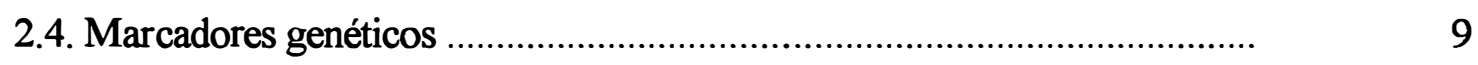

2.4.1. Marcadores moleculares ......................................................... $\quad 10$

2.4.1.1. Polimorfismo de comprimento de fragmentos de restrição ..... 10

2.4.1.2. A técnica de PCR .......................................................... 11

2.4.1.3. Microssatélites ....................................................... 13

2.4.2. Aplicações dos marcadores genéticos.......................................... 15

2.4.2.1. Aplicações dos marcadores genéticos no mapeamento

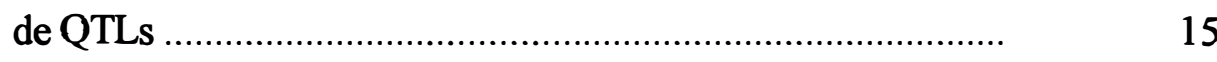

2.4.2.1.1. Polimorfismo genético do hormônio de crescimento .. 17

2.4.2.1.2. Polimorfismo dos genes para proteínas do leite .......... 20

2.4.2.2. Aplicação dos marcadores no estudo de populações ............... 23

2.4.2.3. Distâncias genéticas ....................................................... 28

3. MATERIAL E MÉTODOS ................................................................

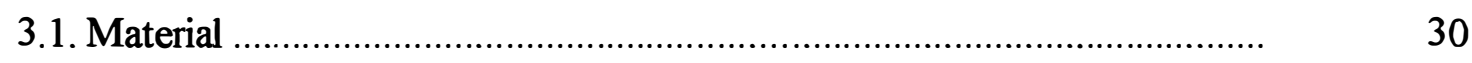

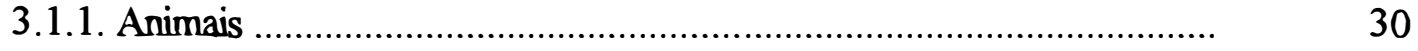




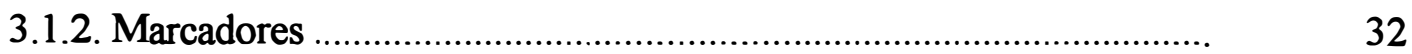

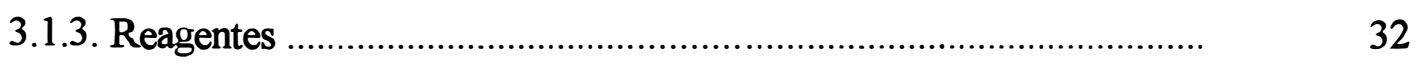

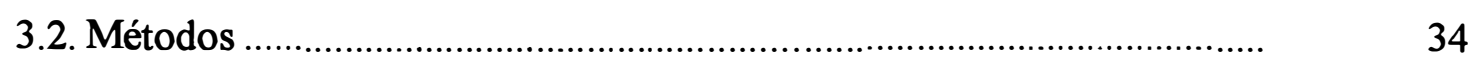

3.2.1. Extração de DNA de amostras de sangue ............................................ 34

3.2.2. Extração de DNA de amostras de sêmen ............................................

3.2.3. Identificação dos genótipos de K-caseína ........................................

3.2.3.1. Amplificação ……………………………………….........

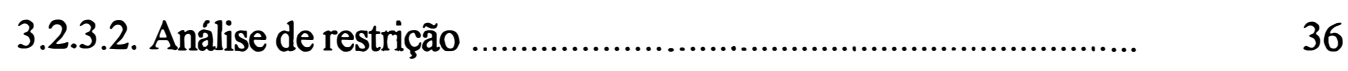

3.2.4. Análise de $\beta$-lactoglobulina ............................................................. 36

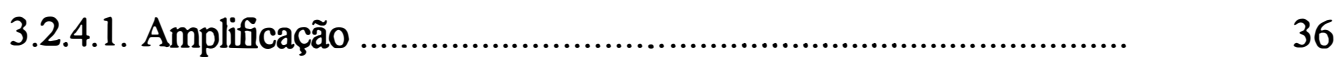

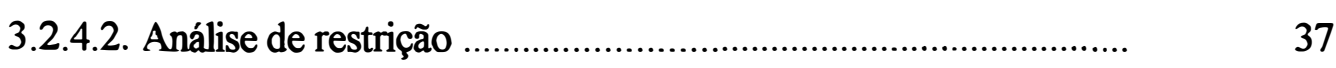

3.2.5. Identificação dos genótipos de hormônio de crescimento .................... 38

3.2.5.1. Amplificação ............................................................................. $\quad 38$

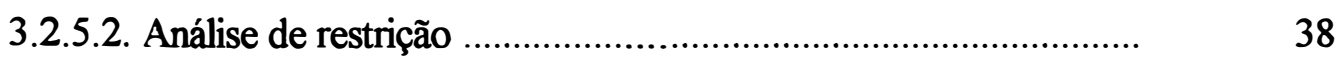

3.2.6. Análise de marcadores de DNA microssatélite ..................................... 38

3.2.6.1. Marcação dos oligonucleotídeos iniciadores ................................ 38

3.2.6.2. Marcação do padrão de tamanho ........................................... 39

3.2.6.3. Amplificação de microssatélites .................................................. $\quad 39$

3.2.6.4. Resolução dos marcadores de DNA microssatélite ..................... $\quad 40$

3.2.7. Métodos estatísticos .............................................................................

3.2.7.1. Estimativa do tamanho dos alelos de microssatélite .................... 41

3.2.7.2. Estimativa das frequências genotípicas ..................................... 42

3.2.7.3. Estimativa das frequências gênicas ............................................. ' $\quad 42$

3.2.7.4. Hipótese de Hardy-Weinberg ................................................

3.2.7.5. Teste de independência das frequências gênicas .........................

3.2.7.6. Estimativa da heterozigosidade ................................................. 45

3.2.7.7. Diversidade gênica .................................................................... 46

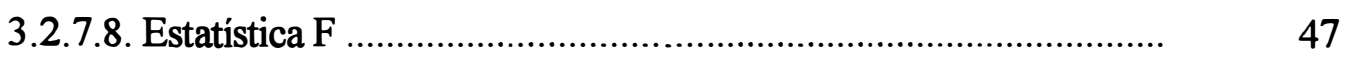

3.2.7.9. Cálculo de $\mathrm{F}$ a partir da genealogia ............................................ 50

3.2.7.10. Distâncias genéticas ............................................................... 50 
4. RESULTADOS E DISCUSSÃO ………………………………………….... 52

4.1. Kappa-caseína ….......................................................................... 52

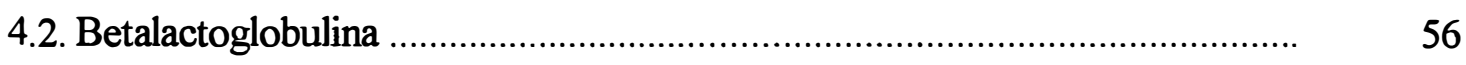

4.3. Polimorfismo do gene do hormônio de crescimento ....................................... 60

4.4. Microssatélite do gene IGF-I .................................................................

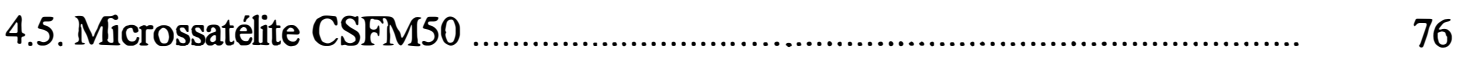

4.6. Microssatélite BM1224 …………………………………………….... 85

4.7. Microssatélite INRA006 .................................................................... 92

4.8. Medidas de variabilidade ………………..................................................... 98

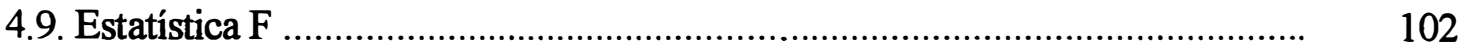

4.10. Distâncias genéticas ................................................................................ 105

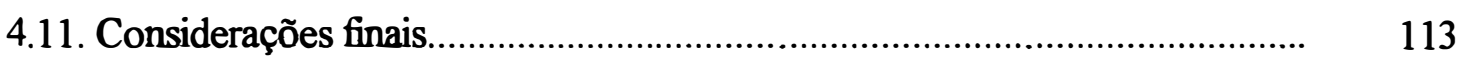

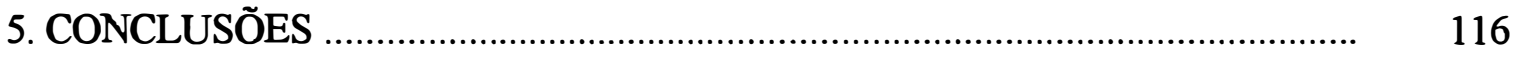

6. REFERÊNCIAS BIBLIOGRÁFICAS .............................................................. 118 
Tabela 1. Classificação da amostra do rebanho Canchim de acordo com a geração.

Tabela 2. Descrição dos marcadores de DNA utilizados no presente estudo.

Tabela 3. Frequências estimadas e erro-padrão da estimativa para os alelos A e B de $\kappa$-caseína em Canchim.

Tabela 4. Distribuição dos genótipos de $\kappa$-caseína nas quatro gerações de Canchim e valores de $\chi^{2}$ para o teste de aderência às proporções de Hardy-Weinberg.

Tabela 5. Distribuição dos genótipos e frequências gênicas de $\kappa$-caseína em animais da raça Charolesa.

Tabela 6. Frequências estimadas e erro-padrão da estimativa para os alelos A e B de $\beta$-lactoglobulina em Canchim.

Tabela 7. Distribuição dos genótipos de $\beta$-lactoglobulina nas quatro gerações de Canchim e valores de $\chi^{2}$ para o teste de aderência às proporções de Hardy-Weinberg.

Tabela 8. Distribuição dos genótipos de $\beta$-lactoglobulina, frequências gênicas e valores de $\chi^{2}$ para o teste de aderência ao equilíbrio de Hardy-Weinberg na raça Charolesa. 
Tabela 9. Frequências dos alelos $\mathrm{L}$ e $\mathrm{V}$ de hormônio de crescimento e respectivos erros - padrões nas quatro gerações de Canchim.

Tabela 10. Análise de regressão entre as frequências do alelo $\mathrm{L}$ de GH e as gerações de Canchim.

Tabela 11. Distribuição dos genótipos de $\mathrm{GH}$ nas quatro gerações de Canchim e valores de $\chi^{2}$ para $o$ teste de aderência às proporções de Hardy-Weinberg.

Tabela 12. Coeficientes de fixação de Wright $(\mathrm{F})$ para o marcador GH nas amostras do rebanho Canchim.

Tabela 13. Distribuição dos genótipos e frequências gênicas para o loco GH em animais da raça Charolesa.

Tabela 14. Frequências dos alelos do MS-IGF-I, erros-padrões das estimativas e valores de qui-quadrado para o teste de independência nas diferentes gerações de Canchim.

Tabela 15. Análise de regressão entre as frequências do alelo 4 de IGF-I e as gerações de Canchim.

Tabela 16. Distribuição dos genótipos de IGF-I nas quatro amostras do rebanho Canchim.

Tabela 17. Teste de aderência ao equilibrio de Hardy-Weinberg para o microssatélite do gene IGF-I. 
Tabela 18. Coeficientes de fixação de Wright (F) para o microssatélite IGF-I. ......

Tabela 19. Distribuição dos genótipos, frequências gênicas e valor de $\chi^{2}$ para o teste de aderência ao equilíbrio de Hardy-Weinberg para 0 microssatélite IGF-I na raça Charolesa.

Tabela 20. Frequências gênicas para o marcador CSFM50 nas quatro amostras de Canchim e valor de $\chi^{2}$ para o teste de independência.

Tabela 21. Análise de regressão entre as frequências do alelo 8 de CSFM50 e as gerações de Canchim.

Tabela 22. Distribuição dos genótipos de CSFM50 nas quatro gerações de Canchim.

Tabela 23. Teste de aderência às proporções de equilíbrio de Hardy-Weinberg para o marcador CSFM50 nas quatro gerações de Canchim.

Tabela 24. Distribuição dos genótipos, frequências gênicas e valor de $\chi^{2}$ para o teste de aderência ao equilíbrio de Hardy-Weinberg para o marcador CSFM50 na raça Charolesa.

Tabela 25. Frequências dos alelos de BM1224 nas gerações de Canchim e valores de $\chi^{2}$ para o teste de independência.

Tabela 26 . Distribuição dos genótipos de BM1224 nas gerações de Canchim .....

Tabela 27. Teste de aderência às proporções de equilíbrio de Hardy-Weinberg para o marcador BM1224 nas quatro gerações de Canchim. 
Tabela 28. Distribuição dos genótipos observados, frequências gênicas e valor de $\chi^{2}$ para o teste de equilibrio de Hardy-Weinberg para o marcador BM1224 na raça Charolesa.

Tabela 29. Frequências gênicas estimadas, erros-padrões e valores de $\chi^{2}$ para o teste de independência para o marcador INRA006 nas quatro gerações de Canchim.

Tabela 30. Distribuição dos genótipos do marcador INRA006 nas quatro gerações de Canchim

Tabela 31. Teste de aderência às proporções de equilíbrio de Hardy-Weinberg para o marcador INRA006.

Tabela 32. Distribuição dos genótipos, frequências gênicas e valor de $\chi^{2}$ para o teste de aderência ao equilíbrio de Hardy-Weinberg para o marcador INRA006 na raça Charolesa

Tabela 33. Estimativas de Diversidade gênica (D) e Heterozigosidade das amostras do rebanho Canchim e da raça Charolesa.

Tabela 34. Médias dos Coeficientes de Fixação por marcador, entre marcadores e teste de $\chi^{2}$ de significância.

Tabela 35. Distribuição dos coeficientes de endogamia $(f)$ calculados pelo pedigri nas quatro gerações de Canchim. 
Tabela 36. Distâncias Euclidianas Médias para os sete marcadores.

Tabela 37. Distância de Nei (1978) considerando os sete marcadores. ............................ 108

Tabela 38. Distâncias Euclidianas Médias considerando os três marcadores de RłFLP. ... 111 
Figura 1. Padrão de fragmentos do produto de amplificação de $\kappa$-caseína digerido com a enzima Hinf1.

Figura 2. Padrão de fragmentos de restrição obtido com a enzima HaeIII nos diferentes genótipos de $\beta$-lactoglobulina.

Figura 3. Padrão de restrição obtido com a enzima $A l u$ I nos diferentes genótipos de $\mathrm{GH}$.

Figura 4. Distribuição das frequências dos alelos de hormônio de crescimento ao longo das gerações de Canchim.

Figura 5. Padrão de bandas observado para os quatro alelos do microssatélite IGF-I.

Figura 6. Distribuição das frequências dos alelos do microssatélite IGF-I ao longo das gerações de Canchim.

Figura 7. Distribuição das frequências do alelo 4 do microssatélite IGF-I ao longo das gerações de Canchim.

Figura 8. Padrão de bandas observado para os alelos de CSFM50.

Figura 9. Distribuição das frequências dos alelos de CSFM50 nas gerações de Canchim. 
Figura 10. Distribuição das frequências do alelo 8 de CSFM50 ao longo das gerações de Canchim

Figura 11. Padrão de bandas observado para os alelos de BM1224.

Figura 12. Padrão de bandas observado para o microssatélite INRA006.

Figura 13. Dendrograma obtido pelo método UPGMA a partir das distâncias Euclidianas Médias estimadas para os sete locos estudados.

Figura 14. Dendrograma obtido pelo método UPGMA a partir das distâncias de Nei (1978) estimadas para os sete locos estudados.

Figura 15. Dendrograma obtido pelo método UPGMA a partir das distâncias EM estimadas para $\kappa$-caseína , $\beta$-lactoglobulina e GH 


\title{
POLIMORFISMO MOLECULAR EM GERAÇÕES DE BOVINOS DA RAÇA CANCHIM.
}

\author{
Autora: LUCIANA CORREIA DE ALMEIDA REGITANO \\ Orientador: PROF. DR. JOÃO LÚCIO DE AZEVEDO
}

\section{RESUMO}

O objetivo desse estudo foi avaliar as frequências gênicas ao longo de sucessivas gerações de acasalamento entre bovinos da raça Canchim (5/8 Charolês, 3/8 Zebu) do rebanho do Centro de Pesquisa de Pecuária do Sudeste - EMBRAPA. Os animais foram classificados de acordo com a geração e uma amostra de 154 indivíduos, representando as gerações 3 a 6 , foi analisada para sete marcadores moleculares. Três marcadores do tipo I (genes) e quatro marcadores do tipo II (microssatélites) foram utilizados. Trinta e seis animais da raça Charolesa foram incluídos nesse estudo, com a finalidade de avaliar as relações genéticas entre o rebanho Canchim e a raça Charolesa atual.

As frequências do alelo $\mathrm{A}$ de $\kappa$-caseína foram de 0,$5 ; 0,72 ; 0,68$ e 0,67 para as gerações 3, 4, 5 e 6 de Canchim, respectivamente. Na raça Charolesa, esse alelo apresentou frequência de 0,51. $\mathrm{O}$ alelo $\mathrm{A}$ de $\beta$-lactoglobulina apresentou frequências de 0,$42 ; 0,46 ; 0,48$ e 0,40, nas gerações 3 a 6 do rebanho Canchim, e de 0,54 na raça Charolesa. As variações das frequências dos alelos de $\kappa$-caseína e $\beta$-lactoglobulina, entre as gerações de Canchim, não foram significativas. As proporções genotípicas para esses dois marcadores foram concordantes com a hipótese de equilíbrio de Hardy-Weinberg nas duas raças.

As frequências do alelo $\mathrm{L}$ do gene do hormônio de crescimento, nas quatro gerações de Canchim, foram 0,96; 0,89;0,93 e 0,79. A variação das frequências gênicas entre as gerações foi significativa $(P \leq 0,01)$, tendo sido observada uma tendência linear de aumento da frequência do alelo $\mathrm{V}$ ao longo das gerações. Desvios significativos das proporções genotípicas esperadas sob equilíbrio de Hardy-Weinberg foram observados 
em todas as gerações $(P \leq 0,02)$, com exceção da geração 3. Na raça Charolesa, a frequência do alelo $L$ foi de 0,74 .

Quatro alelos para o microssatélite da região flanqueadora 5' do gene de IGF-I, localizado no cromossomo 5, foram observados na raça Canchim, com tamanhos entre 231 e 225 pares de bases. A frequência do alelo de 225 pb variou significativamente entre as gerações de Canchim $(P \leq 0,05)$. Entretanto, o aumento da frequência desse alelo, ao longo das gerações, não foi linear. Os desvios com relação às proporções genotípicas de equilíbrio de Hardy-Weinberg foram significativos para a geração 5 e para o total da população $(P \leq 0,01)$. Na raça Charolesa, o alelo de 225 pb não foi observado.

Seis alelos foram identificados na raça Canchim, com tamanhos entre 182 e 168 pb, para o microssatélite CSFM50. Nesse loco do cromossomo 2, apenas a frequência do alelo de $168 \mathrm{pb}$ variou significativamente entre as gerações $(P \leq 0,05)$, tendo apresentado uma tendência de redução linear da frequência. Entretanto, a condição de equilíbrio foi observada em todas as gerações. Os alelos de 182 e 170 pb não foram observados na raça Charolesa. Porém dois alelos, com 180 e 174 pb, que não haviam sido identificados na raça Canchim, foram observados nessa raça.

Seis alelos do microssatélite BM1224, localizado no cromossomo 4 dos bovinos, foram observados na raça Canchim. A variação das frequências gênicas dos alelos predominantes não foi significativa. Os alelos raros não foram testados. Três alelos adicionais foram identificados na raça Charolesa. Dessa forma, um total de nove alelos, com tamanhos entre 178 e 160 pb, foram observados nesse loco. Entre as amostras analisadas, somente a geração 3 de Canchim apresentou desvios significativos com relação às proporções genotípicas de equilíbrio.

O microssatélite INRA006, localizado no cromossomo 3, apresentou sete alelos na raça Canchim, com tamanhos entre 97 e 119 pb. Também nesse loco, a variação ao longo das gerações não foi significativa. A hipótese de neutralidade fenotípica para as características sob seleção nesse rebanho foi reforçada pela aderência às proporções de equilibrio. A raça Charolesa apresentou apenas três alelos para esse marcador, com 113, $111 \mathrm{e} 105 \mathrm{pb}$. 
Apesar de se tratar de um rebanho fechado, as medidas de heterozigosidade e diversidade gênica não indicaram uma tendência de redução da variabilidade genética ao longo das gerações de Canchim. Esses resultados foram consistentes com o esquema de prevenção de endogamia que vem sendo utilizado no programa de melhoramento da raça Canchim. Os coeficientes médios de fixação de Wright $\mathrm{F}_{\text {IS }}$ e $\mathrm{F}_{\text {TT }}$ reforçaram a hipótese de acasalamento preferencial para o polimorfismo do hormônio de crescimento. Valores significativos de $F_{S T}(P \leq 0,05)$ foram obtidos para o polimorfismo de hormônio de crescimento e para o microssatélite IGF-I, indicando que houve diferenciação entre as gerações com relação a esses marcadores. A média de $\mathrm{F}_{\mathrm{ST}}$ para os 7 locos também foi significativa $(\mathrm{P} \leq 0,05)$. As distâncias Euclidiana Média e distância de Nei entre as gerações de Canchim, a raça Charolesa e a raça Nelore foram calculadas com base nos sete marcadores, utilizando dados de literatura para a raça Nelore. As comparações com outros representantes de raças zebuínas foram realizadas utilizando as informações dos três polimorfismos de restrição. Os agrupamentos formados pelo método UPGMA foram consistentes com a origem das raças nas duas análises. 


\title{
MOLECULAR POLYMORPHISM IN GENERATIONS OF CANCHIM BOVINE BREED.
}

\author{
Author: LUCIANA CORREIA DE ALMEIDA REGITANO \\ Advisor: PROF. DR. JOÃO LÚCIO DE AZEVEDO
}

\section{SUMMARY}

This study was developed to evaluate gene frequencies through generations of Canchim cattle (5/8 Charolais, 3/8 Zebu) from the herd maintained at Centro de Pesquisa de Pecuária do Sudeste - EMBRAPA.

Animals were classified according to their generation and a sample of 154 animals, representing generations 3 to 6 , was analyzed for seven molecular markers. Three of these markers were type I (genes) and four were type II (microsatellites). A sample of Charolais breed $(\mathrm{N}=36)$ was included to evaluate genetic relationship between the two breeds.

Frequencies for $\kappa$-casein A allele were $0.5 ; 0.72 ; 0.68$ and 0.67 in Canchim generations 3 to 6. Frequency in Charolais was 0.51 . Frequencies for $\beta$-lactoglobulin $\mathrm{A}$ allele were $0.42 ; 0.46 ; 0.48$ and 0.40 in the four generations of Canchim and 0.54 in Charolais. Gene frequencies did not show significant variation over generations. Genotype frequencies were in Hardy-Weinberg equilibrium in both breeds.

Frequencies of $\mathrm{L}$ allele of growth hormone were $0.96 ; 0.89 ; 0.93$ and 0.79 . Variation in this locus was significant $(P \leq 0.01)$ and the increase of $V$ allele frequency was linear. Except for generation 3, all generations showed significant departures from Hardy-Weinberg proportions $(P \leq 0.02)$. Frequency of allele $L$ in Charolais was 0.74 .

Four alleles were observed for the microsatellite in the 5' flanking region of IGF-I gene in Canchim. Allele sizes ranged from 231 to 225 bp. Frequency variation was 
significant for the latter $(P \leq 0.05)$ although the increase was not linear through generations. Disequilibrium was significant for generation 5 and for the whole population $(\mathrm{P} \leq 0.01)$. The $225 \mathrm{bp}$ allele was not observed in Charolais.

Six alleles, with sizes between 182 and $168 \mathrm{bp}$, were observed for microsatellite CSFM50 in Canchim. A significant $(\mathrm{P} \leq 0.05)$ linear reduction of the $168 \mathrm{bp}$ allele was observed over the generations although departure from equilibrium was not significant in any generation. Two alleles not observed in Canchim were found in the Charolais sample (180 and $174 \mathrm{bp}$ ) however, the alleles with 182 and $170 \mathrm{bp}$ were not present in these animals.

Six alleles were also observed in Canchim for the microsatellite BM1224, from bovine chromosome 4 . The most frequent alleles did not vary significantly among generations. Three additional alleles were present in Charolais comprising 9 alleles at this locus with sizes from 178 to $160 \mathrm{bp}$.

Seven alleles were scored for microsatellite BM1224 in Canchim. Allele sizes varied from 119 to $97 \mathrm{bp}$. Neutrality with respect to traits under selection was suggested by the absence of frequency variation and disequilibrium. Only three alleles were observed in Charolais (113, 111 and $105 \mathrm{bp})$.

Indication of genetic variability loss was not found, even though this herd has been maintained as a closed population for more than 40 years. This finding is in agreement with the avoidance of consanguineous matings used in the breeding program. Average Wright's $F_{I S}$ and $F_{I T}$ coefficients supported the hypothesis of preferential mating for growth hormone polymorphism. $\mathrm{F}_{\mathrm{ST}}$ values were significant for growth hormone and for microsatellite IGF-I. The mean $F_{S T}$ for all loci was also significant, indicating differentiation among generations. Average Euclidian Distance and Nei's Unbiased Distance between Canchim, Charolais and Nelore were estimated based on all loci. Frequencies for Nelore were obtained from the literature. Distances from other zebu breeds were estimated using the 3 RFLP loci. Dendrograms constructed using UPGMA clustering method were consistent with breeds' history in all analysis. 


\section{INTRODUÇÃO}

A formação de raças sintéticas tem sido uma alternativa utilizada para a adaptação de bovinos de corte às. condições tropicais e subtropicais. No Brasil, a raça Canchim, formada pelo cruzamento entre a raça Charolesa e raças zebuínas é um exemplo da aplicação dessa alternativa. Essa raça vem sendo mantida no Centro de Pesquisa de Pecuária do Sudeste - EMBRAPA como um rebanho fechado desde a sua formação em 1953.

Estudos anteriores demonstraram que esse rebanho apresenta uma alta variabilidade genética, tanto para características de produção quanto de fertilidade e portanto representa um recurso genético com potencial para a obtenção de ganhos genéticos razoáveis em programas de seleção. Nesses estudos, ficou também demonstrado que a geração afeta significativamente a produção de fềmeas, provavelmente em função da perda de heterose nas gerações mais avançadas.

$\mathrm{O}$ recente desenvolvimento de um grande número de marcadores moleculares distribuídos ao longo do genoma dos bovinos, permite o acompanhamento e a investigação molecular das mudanças advindas da seleção. Dessa forma, é possível identificar as mudanças genéticas que ocorreram em locos individuais.

A manutenção da variabilidade genética em populações fechadas é uma constante preocupação dos melhoristas uma vez que nem sempre é possível manter um número de animais suficientemente grande para evitar a perda de alelos. Conhecendo-se as frequências gênicas é possível avaliar a estrutura da população após vários ciclos de seleção, fornecendo informações complementares para o desenvolvimento de estratégias de melhoramento. 
Esse trabalho foi desenvolvido com o objetivo de avaliar, utilizando marcadores moleculares, as mudanças de frequências gênicas que ocorreram nesse rebanho ao longo de sucessivas gerações de acasalamento entre os animais bimestiços (5/8 Charolês, 3/8 Zebu). Duas categorias de marcadores foram utilizadas, polimorfismos de comprimento de fragmentos de restrição (RFLPs) e repetições de dinucleotídeos (microssatélites), de modo a permitir a avaliação da variação genética tanto em regiões conservadas do genoma quanto em regiões hipervariáveis. Os locos marcadores foram selecionados de forma a representar diferentes cromossomos e, com excessão do microssatélite BM1224, todos os marcadores analisados são candidatos à associação com características de produção. 


\section{REVISÃO DE LITERATURA}

\subsection{Classificação e origem dos bovinos domésticos}

Os bovinos desempenharam um importante papel na evolução da civilização humana, como fonte de alimento e de força de trabalho. Entre os animais domésticos, são os de maior importância econômica.

Pertencem à ordem Artiodactyla, família Bovidae, tribo Bovini, na qual encontramos quatro gêneros: Bos Linnaeus, Bison H.Smith, Bubalus H.Smith e Syncerus Hodgoon (Nowack \& Paradiso, 1983). Todas as raças de bovinos domésticos conhecidas atualmente, com exceção das raças Bali e Mithan, pertencem ao gênero Bos Linnaeus, sub-gênero Bos. Nesse sub-gênero, dois tipos distintos são reconhecidos: as raças européias sem cupim, comumente denominadas taurinas, e as raças indianas e africanas com cupim, que recebem a denominação genérica de zebuínas. De acordo com a morfologia cranial, o grupo europeu pode ser ainda classificado em dois tipos ancestrais: Bos taurus primigenius, que compreende os animais de chifres longos, e Bos taurus brachyceros, constituído por animais de chifres curtos. A separação entre taurino e zebuíno ainda é controvertida na literatura. Originalmente, o grupo europeu, sem cupim, foi classificado por Linnaeus como espécie Bos taurus, tendo sido o grupo caracterizado pela presença de cupim classificado como uma espécie distinta, Bos indicus. A total ausência de barreira reprodutiva entre os dois grupos levou Zeuner \& Mourant (1963) a propor a classificação de Bos taurus e Bos indicus como espécie Bos primigenius, com as formas domésticas Bos primigenius fd taurus Linnaeus e Bos primigenius fd indicus Linnaeus.

A classificação de Linnaeus parece ser reforçada pela alta divergência genética encontrada nos estudos de polimorfismos bioquímicos e pela presença de diferença 
morfológica do cromossomo Y. Entretanto, a diferença morfológica do cromossomo Y não é considerada como uma evidência definitiva. Alguns autores sugerem que o cromossomo Y acrocêntrico, encontrado em Bos indicus, seria resultante de uma inversão pericêntrica do Y submetacêntrico de Bos taurus (Pinheiro,1984).

$\mathrm{O}$ ancestral de todos os bovinos domésticos foi o Bos primigenius ou aurochs (Epstein \& Mason, 1984). Essa espécie selvagem era encontrada da costa oeste do Pacífico até a costa leste do Atlântico, como também das tundras ao norte até a Índia e norte da África. O centro de origem do aurochs foi provavelmente a Ásia, de onde se espalhou para a Europa e a África, durante o Pleistoceno, dando origem a três raças locais: Bos primigenius namadicus (Ásia); B. p. primigenius (Europa) e B. p. opisthonomus (África).

Os primeiros eventos de domesticação ocorreram no Oriente Médio, provavelmente entre 8.000 a 10.000 anos atrás. As evidências arqueológicas mais antigas indicam a presença apenas de bovinos sem cupim, o que levou alguns autores a defender a hipótese de que os animais com cupim teriam surgido por seleção, natural ou artificial, a partir dos taurinos (Epstein \& Mason, 1984). Entretanto, estudos recentes de evolução de DNA mitocondrial sugerem que a divergência entre os dois tipos de bovinos domésticos teria ocorrido há pelo menos 200.000 anos e que diferentes eventos de domesticação teriam ocorrido (Loftus et al., 1994).

\subsection{A raça Canchim}

A raça Canchim foi iniciada em 1940, por iniciativa do Médico Veterinário e Zootecnista Dr. Antonio Teixeira Vianna, e consiste do cruzamento da raça Charolesa (Bos taurus) e animais de raças zebuínas (Bos indicus).

Segundo Vianna et al. (1978), a raça Charolesa foi escolhida para esses cruzamentos em virtude de seu grande desempenho na produção de came e por sua apreciável adaptação às condições naturais do Brasil central, quando comparada a outras raças européias especializadas para corte.

Os reprodutores da raça Charolesa utilizados, foram importados da França pelo Ministério da Agricultura e mantidos na Fazenda de Criação de Urutaí, estado de Goiás, 
em regime de pasto ou meia estabulação. Em 1936, o plantel foi transferido para a Fazenda de Criação de São Carlos, SP, atual Centro de Pesquisa de Pecuária do Sudeste (CPPSE - EMBRAPA), e utilizado em cruzamentos alternados com fêmeas zebuínas que visavam tanto a produção de animais 5/8 Charolês-3/8 Zebu quanto 3/8 Charolês-5/8 Zebu.

A avaliação dos diferentes produtos de cruzamento permitiu verificar que os bimestiços 5/8 Zebu-3/8 Charolês apresentavam rusticidade semelhante a das raças zebuínas. Entretanto, sua precocidade, conformação para corte e uniformidade eram inferiores as observadas nos bi-mestiços $5 / 8$ Charolês-3/8 Zebu, razão pela qual decidiuse utilizar esse último para a formação de uma nova raça.

A Associação Brasileira de Criadores de Canchim (ABCCAN) foi criada em 11 de novembro de 1971 e, em maio de 1983, a raça foi oficialmente reconhecida. O padrão oficial da raça prevê um tipo morfológico cilíndrico e longilíneo, relativamente grande e alto para a idade, com atributos sexuais secundários bem diferenciados, andar desembaraçado, temperamento ativo sem ser bravio. A pelagem creme e uniforme em várias tonalidades é a desejável, sendo aceitas as pelagens amarela ou branca. São consideradas desclassificantes as deficiências de pigmentação nas mucosas ou na pele.

Para a formação da raça Canchim contribuíram diretamente 53 touros Charoleses, 8 touros Indubrasil e 4 touros Guzerá. As fềmeas foram em sua maioria da raça Indubrasil (127 animais) tendo sido as raças Nelore e Guzerá representadas por 9 fềmeas de cada raça (Alencar et al., 1981). De acordo com esses autores, o grau de parentesco médio aproximado era de 3,1\% para os touros da raça Indubrasil e de $12,5 \%$ para os touros da raça Guzerá. Na raça Charolesa, cada touro era descendente de pelo menos um entre oito touros de origem francesa.

O rebanho do CPPSE tem sido mantido fechado desde a sua formação em 1953, sem introdução de genes de outros rebanhos (Alencar et al., 1981). O sistema de criação foi exclusivamente a pasto com suplementação mineral uma vez por semana. As pastagens eram constituídas principalmente de capins pangola (Digitaria decumbens), colonião (Panicum maximum), gordura (Melinis minutiflora) e jaraguá (Hyparrhenia rufa) que foram gradativamente invadidas pela grama batatais (Paspalum notatum) a 
partir de 1966. Melhorias nas condições das pastagens foram iniciadas a partir de 1977, com a introdução de Brachiaria decumbens, Panicum maximum c.v. "Makueni"e "Green panic" e Pennisetum purpureum, além da suplementação permanente com sais minerais (Alencar \& Barbosa, 1981).

De acordo com os mesmos autores, até 1977 a eliminação de fềmeas do rebanho se deu principalmente por motivo de doença ou acidente. A partir daquele ano, os seguintes critérios foram utilizados para a seleção de fềmeas: possuir registro genealógico, ser aprovada em exame ginecológico e atingir peso mínimo de $310 \mathrm{~kg}$ por ocasião da primeira estação de monta. Além disso, as fềmeas que não apresentaram diagnóstico positivo de gestação em duas estações de monta consecutivas foram eliminadas do rebanho. $\mathrm{O}$ descarte anual de fềmeas é de aproximadamente $20 \%$.

A seleção de machos foi realizada pelo método de níveis independentes. Os três níveis utilizados foram: Obtenção de registro genealógico; avaliação andrológica, incluindo a medida de perímetro escrotal, e índice ajustado de peso aos 12 meses de idade. Este último foi dado pela razão entre o peso ajustado do animal e a média de peso ajustado dos contemporâneos (Alencar \& Barbosa $^{1}$ ).

Além do rebanho mantido pela EMBRAPA, criadores particulares têm utilizado a raça Canchim em cruzamentos ou como raça pura. Três esquemas de acasalamentos são aceitos pela Associação para a obtenção do Canchim e, entre os criadores particulares, a raça zebuína mais utilizada para esses cruzamentos é a raça Nelore. Detalhes sobre a obtenção do Canchim em propriedades particulares são encontrados em Alencar (1986). Atualmente mais de 33.000 animais Canchim puros são registrados pela ABCCAN.

\subsection{As raças utilizadas na formação do Canchim}

\subsubsection{A raça Charolesa}

Essa raça surgiu a partir de uma raça geográfica de bovinos de pelagem creme que habitava o distrito de Charollais (French et al., 1968). Esses animais se concentraram por

\footnotetext{
1 Alencar,M.M.; Barbosa, P.F. Centro de Pesquisa de Pecuária do Sudeste-EMBRAPA, São Carlos. Comunicação pessoal, 1996.
} 
algum tempo nas regiões montanhosas da França, expandindo-se posteriormente para outras regiões daquele pais. De acordo com Rouse (1972), a base ancestral foi provavelmente a mesma do gado Simmental da Suíça e Alemanha, tendo sido selecionada para a cor da pelagem clara. Alguma introgressão de animais da raça inglesa Shorthorn ocorreu durante o início do século XIX mas a maioria dos autores considera que a participação daquela raça tenha sido de pequena importância no desenvolvimento da raça Charolesa.

A partir de sua origem como raça de tripla aptidão (carne, trabalho e leite), foi gradativamente transformada em raça especializada para corte caracterizando-se por animais grandes e pesados, de corpo largo e profundo com quartos traseiros bastante musculosos. A pele, chifre e mucosas são despigmentados e a pelagem é branca ou creme.

A introdução da raça no Brasil foi iniciada por pequenas importações de animais de origem francesa, a partir de 1885. Esses animais foram adquiridos por criadores do Rio Grande do Sul e utilizados em cruzamentos com os rebanhos locais. Duas importações oficiais foram realizadas nos anos de 1924 e 1925 e, segundo o Herd Book Collares (1982), chegaram a aproximadamente uma centena de reprodutores .

O livro de registros da raça no Brasil foi aberto em 1927 com duas fềmeas importadas da França e os touros que haviam sido importados até então. Em sua maioria, eram animais de genealogia incompleta, mas que possuíam documentação fornecida pelo Herd Book Charollais. A grande maioria das importações subsequentes foi realizada por criadores particulares sendo que, até 1981, o total de importações registradas pelo Herd Book era de 1.235 animais. Além dessas importações, a introdução de material genético de outros países também tem se dado através da utilização de sêmen importado.

A adaptação da raça às condições serranas do sul do país foi responsável pelo seu intenso desenvolvimento. Atualmente tem sido verificada uma tendência de redução no volume de importações de sêmen, bem como de diversificação da origem desse material. Sêmen de reprodutores argentinos, uruguaios e norte-americanos tem sido utilizado, tomando-se o cuidado de garantir que a ascendência desses reprodutores termine em animais do pais de origem.

Animais de variedade mocha são reconhecidos pela Associação de Criadores. O primeiro registro de um animal nascido no Brasil com essa característica foi realizado em 
1966. A preferência dos criadores levou à expansão da variedade mocha, reforçada pela importação de animais mochos da Argentina.

\subsubsection{As raças zebuínas}

A raça zebuína mais utilizada na formação da raça Canchim foi a Indubrasil. Essa raça foi formada no início desse século, por criadores do triângulo mineiro, em virtude do conceito vigente à época de que os animais de origem indiana deviam ser utilizados como produtos de cruzamento entre raças. De acordo com Santiago (1985), o Indubrasil resultou do cruzamento das diversas raças zebuínas existentes no Brasil, entre outras, as raças Ongole, Hissar, Mehwati e Sindi. Os produtos desses cruzamentos apresentavam maior precocidade e maior peso à idade adulta.

A preferência dos diversos criadores e a disponibilidade de representantes das diversas raças zebuínas parecem ter norteado os cruzamentos no início da formação da raça. A preocupação em utilizar reprodutores puros e obter um padrão racial típico de zebuínos resultou na seleção de animais com orelhas compridas, barbela e umbigo bem desenvolvidos (Santiago, 1985). Apesar disso, o Indubrasil apresenta algumas qualidades que merecem ser destacadas, principalmente a capacidade de ganho de peso em condições tropicais. De acordo com Rosa et al. (1984), a raça apresentou as maiores médias de peso ao nascimento e às idades 205 dias, 365 dias e 550 dias no Controle de Desenvolvimento Ponderal das Raças Zebuínas, realizado no período de 1975 a 1982. Entretanto, em consequência da ausência de um esquema de cruzamento direcionado, a fixação das características da nova raça tomou-se um desafio aos criadores e muitos acabaram por optar pela dedicação às raças puras. Os núcleos que persistem até hoje são encontrados no norte de Minas Gerais e em alguns estados do Nordeste, particularmente no Sergipe.

A raça Nelore foi formada a partir do Ongole, original do sul da Índia, mas sofreu infusão de raças do tipo Misori, que se caracterizam por perfil convexo e chifres alongados (Santiago, 1972). Desses cruzamentos obteve-se um tipo racial longilíneo, com ossatura bem desenvolvida e pelagem clara sobre pele pigmentada. Os animais caracterizam-se ainda por um temperamento ativo e grande resistência aos ectoparasitas e às doenças tropicais (Rosa et al., 1984). 
O Nelore ocupa a posição de maior destaque entre as raças zebuínas criadas no Brasil, sendo também a raça que tem sido mais trabalhada sob o ponto de vista de melhoramento para produção de carne. De acordo com Lima (1989), a evolução do peso em diferentes idades dos animais da raça Nelore, no período entre 1958 e 1987, foi de 10,3 $\mathrm{kg} /$ ano para os machos jovens e de $8,5 \mathrm{~kg} /$ ano para os touros. É importante ressaltar que esse aumento foi também resultante de melhorias nas condições ambientais das criações.

A raça Guzerá foi a raça predominante no início da introdução dos zebuínos no Brasil. Formada a partir de animais da raça indiana Kankrej e outros representantes do mesmo grupo, caracterizados por chifres longos em forma de lira, perfil côncavo e orelhas grandes e pendentes. A padronização da raça para fixar as características do Kankrej foi obtida através do serviço de Registro Genealógico e da introdução de reprodutores puros em 1960 e 1962 (Santiago, 1985). De acordo com Lima (1989), por ser originário de uma região da Índia com pouca disponibilidade de água, o Guzerá é um animal bastante adaptado às condições semi-áridas da região Nordeste do Brasil.

\subsection{Marcadores genéticos}

Os marcadores genéticos são características de herança simples que permitem a determinação do genótipo a partir do fenótipo do indivíduo, fornecendo informações importantes para a análise genética de uma espécie. Para a comparação entre populações, os marcadores devem ser neutros para a adaptação e sobrevivência do animal, preferencialmente codominantes e estáveis ao longo do desenvolvimento.

Os primeiros marcadores disponíveis foram as mutações que produziam alterações morfológicas como, por exemplo, o nanismo, a ausência de asas em Drosophila e a ausência de pelos em camundongos. Entretanto, tais mutações são pouco frequentes nas populações naturais, nas quais a maior parte da variação genética é de caráter contínuo, e frequentemente comprometem a adaptação do indivíduo (Tanksley, 1993).

A partir da década de 30, o polimorfismo de antígenos eritrocitários passou a ser investigado, fornecendo uma nova classe de marcadores para o estudo de populações em animais. A análise de marcadores foi ampliada com o desenvolvimento de técnicas de 
eletroforese de proteínas associadas a métodos de coloração histoquímica (Hunter \& Market, 1957) que permitiram que a variação genética das isoenzimas passasse a ser estudada. Esses marcadores têm sido intensamente utilizados para investigar a estrutura das populações, elucidando questões como fluxo gênico em populações naturais, dispersão e filogenia. Apesar disso, apenas uma parte da variação genética pode ser observada, aquela resultante de mutações que ocorrem em regiões codificadoras do genoma e resultam em alteração detectável do produto gênico. Além disso, as isoenzimas podem sofrer influência do ambiente, e podem sofrer variações de acordo com a idade e o tecido utilizado.

Essa limitação foi superada com o desenvolvimento das técnicas de análise de DNA que serão discutidas a seguir.

\subsubsection{Marcadores moleculares}

\subsubsection{Polimorfismo de comprimento de fragmentos de restrição}

A caracterização do polimorfismo de DNA tornou-se possível com a descoberta das endonucleases de restrição da Classe II, capazes de cortar a molécula de DNA em sítios específicos, denominados sítios de restrição (Kelly \& Smith, 1970). O número de cortes efetuados por uma determinada enzima de restrição é função do número de sítios de restrição presentes ao longo da molécula de DNA. A ocorrência de variação individual no número e tamanho dos fragmentos formados pela digestão do DNA com uma enzima de restrição foi demonstrada por Grodzicker et al. (1974), em adenovírus. Essa variação é o resultado de mutações que eliminam ou criam sítios de restrição para uma determinada enzima e foi denominada Polimorfismo de Comprimento de Fragmentos de Restrição ou RFLP.

O método desenvolvido para adenovírus não produziu resultados satisfatórios em eucariotos superiores, em fuunção do tamanho do genoma. Nessas espécies, o número de fragmentos resultantes da digestão com enzimas de restrição é muito grande. Consequentemente, tentativas de separá-los por tamanho em gel de eletroforese produziram um rastro ao invés de bandas discretas. A solução para esse problema surgiu com o desenvolvimento da técnica de Southern (1975), na qual os fragmentos separados são imobilizados em um suporte sólido e desnaturados. Explorando a tendência da molécula de DNA de formar duplas-fitas complementares, Southern utilizou uma sequência de DNA fita- 
simples, marcada com ${ }^{32} \mathrm{P}$, como sonda. Como resultado, apenas os fragmentos complementares à sequência utilizada como sonda foram revelados.

Estas sondas de DNA podem ser de regiões codificadoras ou não. $\mathrm{O}$ emprego de sondas de DNA complementar ao RNA mensageiro (cDNA) é o mais comum e apresenta a vantagem de não conter sequências repetitivas. As sondas anônimas, obtidas a partir de fragmentos de DNA ao acaso, possibilitam a rápida obtenção de marcadores para construção de mapas de ligação e permitem a análise de regiões não codificadoras do DNA. Porém, em virtude da abundância de DNA repetitivo no genoma dos eucariotos, essas sondas devem ser submetidas a um processo de seleção de forma a garantir que apenas aquelas que representam sequências de cópia única sejam empregadas, assegurando a obtenção de marcadores unilocais.

Um aspecto importante dos marcadores de RFLP é a prevalência de dialelismo. Muitos dos locos marcadores descritos são dialélicos, quer originados de mutações de ponto ou de mutações estruturais. Marcadores dialélicos são bastante limitados para o mapeamento genético em populações segregantes (Smith \& Simpson, 1986), em função do número de cruzamentos informativos. Por exemplo, quando dois indivíduos heterozigotos, para dois determinados alelos, são acasalados, não se pode identificar qual foi o progenitor que contribuiu com um determinado alelo. Outras desvantagens são a presença de alelos raros, fazendo com que muitas populações apresentem um padrão monomórfico. Apesar dessa limitação, em 1990 mais de 120 locos haviam sido mapeados em bovinos ( Kennedy et al., 1990).

\subsubsection{A técnica de PCR}

Uma das mais recentes contribuições ao estudo de marcadores moleculares foi o desenvolvimento da técnica de Reação em Cadeia da Polimerase (PCR). Essa técnica foi desenvolvida por Mullis em 1983 (Mullis,1990), mas sua importância só ficou demonstrada com a publicação dos primeiros trabalhos de aplicação da PCR em diagnóstico de doenças (Saiki et al., 1985). A técnica consiste na replicação do DNA in vitro, catalisada por uma DNA polimerase termoestável. A reação requer a presença dos quatro tipos de nucleotídeos e de oligonucleotídeos complementares às extremidades da região do DNA que se deseja 
amplificar. Os oligonucleotídeos ("iniciadores" ou "primers") funcionam como ponto de início para a síntese de uma fita de DNA complementar à fita molde. Cada ciclo de PCR envolve a desnaturação da molécula de DNA alvo, através da elevação da temperatura para 92 a $95^{\circ} \mathrm{C}$, o anelamento dos "primers" pela redução da temperatura até o ponto ideal para cada "primer", e a extensão da síntese da nova fita de DNA. Como as fitas recém sintetisadas funcionam como molde para o próximo ciclo, ao final de vários ciclos obtém-se um acúmulo exponencial de cópias da região delimitada pelos "primers". A temperatura ideal de anelamento depende basicamente do tamanho e da sequência dos oligonucleotídeos utilizados.

A extensão da síntese da nova fita de DNA era originalmente catalisada pelo fragmento Klenow da DNA-polimerase I que, por ser termolábil, exigia que fosse adicionada a cada novo ciclo de PCR

A utilização de uma DNA polimerase (Taq polimerase) isolada da bactéria Thermus aquaticus, capaz de catalisar a síntese de DNA a $72^{\circ} \mathrm{C}$ e se manter estável a $92^{\circ} \mathrm{C}$, representou um grande avanço na técnica de PCR (Saiki et al., 1988).

A técnica de PCR produziu um grande impacto na análise de marcadores de DNA, principalmente em função de sua simplicidade e sensibilidade. O princípio de amplificação de DNA in vitro tem sido utilizado para o desenvolvimento de técnicas de sequenciamento, clonagem e para o desenvolvimento de novos marcadores como os RAPDs (Polimorfismos de DNA amplificados ao acaso), AFLPs (Polimorfismos de Comprimento de Fragmentos Amplificados) (Ferreira \& Grattapaglia, 1995) e microssatélites.

Além disso, muitos dos polimorfismos descritos pelo método de Southern têm sido transformados em marcadores baseados em PCR específica.

Para a análise de RFLP através de PCR as extremidades da sonda que revelou o polimorfismo são sequenciadas e essas sequências são utilizadas para a síntese de "primers" complementares. Com o crescente desenvolvimento dos projetos de sequenciamento do genoma das principais espécies animais, os "primers" podem também ser desenvolvidos a partir de sequências publicadas, selecionando-se aquelas que delimitam polimorfismos descritos. 
Esses "primers" são utilizados para amplificar a região que contém os sítios polimórficos de restrição. Os fragmentos produzidos pela digestão dos produtos de amplificação podem ser então analisados em géis de agarose (Ferreira e Grattapaglia, 1995).

A quantidade de DNA molde necessária para a detecção do produto de amplificação toma possível a análise do DNA obtido de uma única célula. O PCR-RFLP tem sido aplicado no diagnóstico de doenças hereditárias em humanos (Saiki et al., 1988) e em animais (Coutinho \& Regitano, 1995).

\subsubsection{Microssatélites}

Além do polimorfismo das sequências de DNA de cópia única, uma grande variabilidade está presente nas regiões de DNA repetitivo.

Os genomas dos eucariotos abrigam uma grande quantidade de DNA repetitivo, classificados de acordo com o número de nucleotídeos e a complexidade da sequência que compõe as repetições. As diferentes classes são também caracterizadas por comportamento típico quanto à distribuição no genoma e quanto ao mecanismo envolvido em suas origens (Jobse et al., 1995).

A variabilidade de sequências repetitivas foi demonstrada por Bell et al. (1982), e vem sendo utilizada para a produção de marcadores multilocais desde o desenvolvimento da técnica de "DNA fingerprint" (Jeffreys et al., 1985).

Um avanço importante na obtenção de marcadores unilocais veio da utilização de uma classe de DNA repetitivo, as sequências microssatélites. Os microssatélites são caracterizados por repetições em tandem de um mono, di ou trinucleotídeo mais frequente, localizado dentro de regiões de sequência única. Cada bloco de repetições é geralmente menor do que 100 pares de nucleotídeos (Tautz, 1989). Do mesmo modo que outras regiões repetitivas do genoma, a variação do número de repetições em cada loco é resultante de erros no deslocamento da DNA polimerase durante a replicação do DNA.

Os microssatélites poli(G) e poli(A) são os mais simples enquanto que poli(GT) são os mais frequentes, aparecendo em aproximadamente 5 a $10 \times 10^{4}$ locos individuais no genoma dos mamíferos (Soller, 1990). Muitos outros microssatélites foram identificados até 
o momento, e é possivel que qualquer sequência mais comum de poucos nucleotídeos possa representar um microssatélite no genoma de eucariotos.

Os microssatélites podem ser amplificados de maneira específica pela técnica de PCR utilizando "primers" que contém parte da sequência flanqueadora de cópia única (Tautz, 1989).

A amplificação resulta em produtos de diferentes tamanhos, em função do número de cópias da sequência microsatélite delimitada pelos "primers". Uma vez que os oligonucleotídeos utilizados são complementares às sequências de cópia única que flanqueiam os microssatélites, obtém-se marcadores unilocais, altamente polimórficos e de herança codominante.

Distorções da segregação podem surgir em decorrência da "expansão" ou "contração" do microssatélite durante a meiose. A frequência desses eventos é da ordem de $10^{-4}$ a $10^{-5}$ por loco por gameta (Holmes,1994), suficientemente baixa para permitir seu uso como marcador genético. Entretanto, em presença de alterações do sistema de reparo, a taxa de mutação pode aumentar de 100 a 1000 vêzes. A instabilidade resultante tem sido associada com o desenvolvimento de alguns tipos de câncer (Simpson, 1996), e de doenças hereditárias como a síndrome do cromossomo $X$-frágil.

Considerando a frequência dessas sequências e um tamanho médio do genoma de mamífero de $3 \times 10^{9}$ pares de nucleotídeos, seria possível construir mapas genéticos com aproximadamente 10.000 locos microssatélites (Soller, 1990).

Recentes progressos tem sido alcançados em decorrência do grande estímulo ao programa Genoma Humano, cujo objetivo é mapear e sequenciar todos os genes da espécie. Por meio do mapeamento comparativo, um avanço significativo deve ser alcançado também em outras espécies de mamíferos.

A conservação de padrões cariotípicos, sequências codificadoras e de ordem de genes nos cromossomos tem sido descrita em muitas espécies (Womack \& Moll, 1986). A extensão desse conceito de conservação para abranger também as sequências repetitivas tem se mostrado verdadeira. Kirkpatrick (1992), comparou a sequência do gene do Fator de Crescimento Semelhante à Insulina do tipo I (IGF-I) de ratos, humanos e bovinos. Uma repetição $(\mathrm{CA})_{\mathfrak{n}}$ foi encontrada na região flanqueadora do gene em todas as espécies 
estudadas. "Primers" complementares às sequências de maior conservação das regiões que flanqueiam a repetição foram utilizados para amplificar o microssatélite em bovinos, suínos e ovinos. Esses resultados sugerem que a conservação ocorre também quanto à organização dos padrões repetitivos embebidos em sequências de cópia única, entrando em conflito com a noção de que as sequências repetitivas sejam evolucionariamente neutras.

A utilização de PCR para a análise desses marcadores representa uma importante redução no tempo despendido para a identificação dos genótipos, além de permitir a identificação do genótipo de embriões. Esse fato, aliado ao intenso polimorfismo, toma os microssatélites marcadores bastante adequados para a construção de mapas genéticos e identificação de locos que controlam caracteres quantitativos (QTLs), principalmente em espécies onde o número de progênies é limitado (Massey \& Georges, 1992).

\subsubsection{Aplicações dos Marcadores Genéticos}

Os marcadores genéticos tem sido utilizados em diversas aplicações, entre elas na resolução de casos de paterninade duvidosa, na identificação individual e no diagnóstico de doenças.

No melhoramento animal, eles tem desempenhado importante papel na localização de regiões cromossômicas que contribuem para a variação de um caráter quantitativo, na determinação da estrutura das populações e no esclarecimento das relações genéticas entre diferentes populações. Esses últimos aspectos serão abordados em maior detalhe a seguir.

\subsubsection{Aplicações dos marcadores genéticos no mapeamento de QTLs}

O melhoramento genético de bovinos tem sido conduzido sob os princípios da genética quantitativa, alcançando ganhos de 1 a $2 \%$ ao ano em gado leiteiro (Wiggans et al.,1988). Em bovinos de corte, Barlow (1978) encontrou um ganho genético anual médio de $1,5 \mathrm{~kg}$ para peso à desmama e 3,8 $\mathrm{kg}$ para peso aos 12 meses.

A existência de genes principais, que contribuem com uma grande parte da variação fenotípica de um caráter quantitativo, tem sido demonstrada. Alguns exemplos são o gene da hipertrofia muscular (mh) em bovinos (Nott \& Rollins, 1979), a susceptibilidade à síndrome 
de estresse em suínos (Peloso, 1994) e o gene de fertilidade (Fec) dos ovinos (Lanneluc et al., 1994).

Essa situação, entretanto, pode ser considerada como exceção. Apesar da existência de genes principais, a maioria dos caracteres quantitativos deve ser controlada por um grande número de genes, cada um com pequeno efeito sobre o caráter (Massey \& Georges, 1992).

Thoday (1961) defendeu a hipótese de que se a segregação de um gene marcador pudesse ser utilizada para identificar e estimar o efeito de um poligene, e se um número suficiente de marcadores estivesse distribuído pelo genoma de uma espécie, seria possível mapear e caracterizar todos os poligenes que afetam um caráter quantitativo.

O desenvolvimento de marcadores para alcançar esse objetivo tem se valido basicamente de duas estratégias. A primeira utiliza marcadores aleatórios para a construção de mapas genéticos saturados. Esses marcadores são então avaliados em estudos de correlação com características de interesse econômico e utilizados na identificação de locos que afetam caracteres quantitativos ou QTLs (Geldermann, 1975). O sucesso dessa estratégia depende primariamente da construção de mapas de ligação detalhados, com marcadores dispostos a intervalos de $20 \mathrm{cM}$. A construção de tais mapas tornou-se possível com a utilização de marcadores altamente polimórficos, particularmente aqueles que exploram o polimorfismo de sequências repetitivas de DNA (Soller, 1990). Em bovinos, dois mapas genéticos publicados por Bishop et al. (1994) e Barendse et al. (1994) fornecem marcadores suficientes para uma cobertura de $90 \%$ do genoma a uma distância média de $20 \mathrm{cM}$. Os primeiros resultados do emprego desses marcadores em análises de intervalo têm sido relatados. Ron et al. (1994a) identificaram um QTL no cromossomo 21 dos bovinos com um efeito de 0,2 desvios-padrões fenotípicos para produção de leite e 0,16 desvios-padrões para proteína total. Georges et al. (1995), encontraram fortes evidências da presença de QTLs para características de produção de leite nos cromossomos 1, 6, 9, 10 e 20 dos bovinos. Os efeitos dos diferentes QTLs contribuíram com 11 a 52\% da variância total dentro de famílias de meios-irmãos.

O sucesso desses experimentos pode também ser atribuído ao desenvolvimento de métodos estatísticos e delineamentos genéticos adequados (Weller et al., 1990). 
A disponibilidade de grandes familias de touros tem permitido um maior avanço no mapeamento de QTLs para características de produção de leite.

Em bovinos de corte, cruzamentos direcionados entre as raças Angus e Brahman foram utilizados para a produção de famílias de referência, em uma colaboração entre a Universidade A\&M do Texas e a Estação Experimental de Angleton. A análise de intervalos permitiu a identificação de pelo menos dois QTLs no cromossomo 2, próximos ao microssatélite CSFM50, que influenciam o peso da desmama até a maturidade (Davis \& Taylor, 1995).

A segunda estratégia de identificação de QTLs se baseia na deteç̧ão de polimorfismo em genes que estão diretamente relacionados com a característica de produção, denominados genes candidatos. Alguns genes candidatos que vem sendo investigados são: o gene do hormônio de crescimento, do fator de crescimento semelhante à insulina, da

prolactina e de proteínas do leite como as caseínas e lactoglobulinas, que são discutidos a seguir.

\subsection{Polimorfismo genético do Hormônio de Crescimento}

A regulação hormonal do crescimento dos animais envolve interações complexas entre uma diversidade de hormônios. Entre esses, o hormônio de crescimento, também denominado somatotropina, desempenha um papel fundamental. As primeiras evidências sobre os efeitos desse hormônio no crescimento de animais foram observadas na década de 30, quando ficou demonstrado que a administração de extratos de hipófise de bovinos aumentava, a longo prazo, o ganho de peso em camundongos (Boyd \& Bauman 1989). Utilizando metodologia semelhante, pesquisadores russos demonstraram que o extrato de hipófise anterior aumentava significativamente a produção de leite em bovinos. Esses trabalhos despertaram um grande interesse na comunidade científica, o que resultou em um rápido desenvolvimento dos conhecimentos sobre esse hormônio.

A secreção pela hipófise anterior é regulada por duas proteínas: o fator de liberação de hormônio de crescimento, com efeito positivo, e a somatostatina, com efeito inibitório. Essa liberação apresenta um padrão pulsátil fundamental para a ação do hormônio (Davis, 1988). 
Os efeitos sobre o crescimento são observados em diversos tecidos, entre eles os tecidos ósseo, muscular e adiposo. Esses efeitos são decorrentes tanto da ação direta do GH quanto da ação mediada pelos fatores de crescimento semelhantes à insulina (IGF) tipo I e tipo II, estimulando a proliferação celular e os processos metabólicos associados à deposição de proteínas. $\mathrm{O}$ metabolismo de lipídeos, carboidratos e minerais é também profundamente afetado. Na realidade, os efeitos do GH são tão variados que não permitem o estabelecimento de uma hipótese única sobre seu mecanismo de ação. Esses efeitos podem ser classificados em duas categorias: os efeitos associados à regulação da partição dos nutrientes absorvidos da dieta e os efeitos sobre a proliferação celular (Boyd \& Bauman 1989).

O hormônio de crescimento $(\mathrm{GH})$ é de natureza proteica. Em humanos, é secretado como um complexo heterogêneo de peptídeos, sendo a forma predominante a de $22 \mathrm{kDa}$. As demais formas são resultantes de transformações pós-traducionais, formação de agregados de dois a cinco monômeros e de fragmentos resultantes da proteólise (Boyd \& Bauman, 1989).

A somatotropina bovina pode ter 191 ou 190 aminoácidos. As duas formas são produzidas pela remoção altemativa do peptídio sinal, deixando uma alanina ou uma fenilalanina na posição aminoterminal, respectivamente. Além das formas de 190 e 191 aminoácidos, duas variantes genéticas da proteína somatotropina foram identificadas em 1971, pela análise eletroforética da proteína (Bauman \& Vernon, 1993). Essas variantes diferem pela presença de uma leucina ou de uma valina na posição 127. Com a determinação da sequência do gene do hormônio de crescimento dos bovinos por Woychik et al. (1982), a identificação desse polimorfismo passou a ser realizada pela técnica de PCR-RFLP, uma vez que a substituição de leucina por valina altera o sítio de restrição da enzima AluI ( Lucy et al., 1991).

A frequência dos alelos que codificam a forma leucina $(L)$ e a forma valina $(V)$ foi determinada para várias populações de bovinos. De acordo com DeNise ${ }^{2}$, as frequências da forma V nas raças Angus, Gelbvieh, Hereford, Limousin, Simmental e Holandesa foram $0,26,0,47,0,35,0,24,0,27$ e 0,09 , respectivamente. Na raça Brahman apenas o alelo $\mathrm{L}$ foi

2 DeNise, S. University of Arizona. Comunicação pessoal, 1996. 
observado. No Brasil, a fixação do alelo L foi observada nas raças Gir e Guzerá ( Coutinho ${ }^{3}$ ) e em 65 animais da raça Nelore (Rosa et al., 1996). A única indicação da presença do alelo $\mathrm{V}$ em raças pertencentes ao grupo dos zebuínos foi descrita por Mitra et al. (1995), que encontraram esse alelo com frequência de 0,04 em animais da raça Sahiwal na Índia.

Schlee et al. (1994a), analisaram a relação entre as variantes L e V e a concentração plasmática de hormônio de crescimento e IGF-1. A concentração de GH foi maior em animais homozigotos para o alelo L, e a de IGF-1 foi superior nos animais heterozigotos e homozigotos para o alelo V. De acordo com Schlee et al. (1994b), o genótipo LV foi associado com maior ganho de peso por dia em touros da raça Simmental, tendo sido os homozigotos para o alelo V superiores para escore de carcaça.

Outros polimorfismos foram descritos para esse gene. Utilizando a técnica de RFLP, Beckmann et al. (1986) identificaram um polimorfismo resultante de um evento de inserção/deleção de aproximadamente 900 pares de base na região 3' do gene, que alterava simultaneamente o padrão de fragmentos obtidos com a enzima $B g l \Pi$ e com BamHI.

Theilmann et al. (1989) identificaram quatro fragmentos distintos, complementares a sondas de cDNA desse gene, resultantes da digestão com a enzima Taq I . A frequência desses alelos variou entre as raças estudadas, tendo sido o fragmento de 6,2 kilobases prevalente nas raças européias. Estudos de associação com características de produção, em gerações $F_{2}$ de cruzamentos Angus-Brahman e Brahman-Hereford, sugerem que esse polimorfismo influencia o peso ao nascimento e diâmetro da região dos ombros em bovinos de corte (Rocha et al. 1992). Essa associação foi significativa quando o efeito foi considerado como efeito materno e todos os alelos associados com a redução das medidas de peso e diâmetro eram provenientes da raça Brahman.

Unanian et al. (1994), descreveram um polimorfismo para a enzima HaeIII em uma região de 441 pares de base que continha o $5^{\circ}$ exon e a região flanqueadora $3^{\prime}$ do gene $\mathrm{GH}$.

\footnotetext{
3 Coutinho,L.L.Departamento de Zootecnia, ESALQ/USP. Comunicação pessoal, 1996 .
} 
Outros genes considerados candidatos para o estudo de associação com características de crescimento são os genes para os fatores de crescimento semelhantes à insulina (IGFs) ou somatomedinas.

\subsection{Polimorfismo dos genes para proteínas do leite}

Dois grupos principais de proteínas compõem o leite dos bovinos: caseínas e proteínas do soro. As caseínas são representadas por quatro frações denominadas $\alpha_{s 1}, \alpha_{s 2} \beta$ e $\kappa$-caseína. As proteínas do soro são principalmente as $\beta$-lactoglobulinas, $\alpha$-lactoalburninas e, em menor proporção, soro-albuminas e imunoglobulinas (Eigel et al., 1984).

Cada fração proteica é determinada por um único loco. A fração $\beta$-caseína apresenta 10 padrões eletroforéticos, controlados pelos alelos $\mathrm{A}^{1}, \mathrm{~A}^{2}, \mathrm{~A}^{3}$ e $\mathrm{B}$. Dois alelos codominantes, denominados A e B, foram descritos para $\beta$-lactoglobulina. As formas de $\alpha_{\text {s1-caseína são }}$ governadas pelos alelos B e C (Lin et al., 1992). A $\kappa$-caseína apresenta quatro formas A, B, C e D (Miranda et al., 1993).

Uma vez que a expressão das caseínas ocorre exclusivamente no tecido mamário, a identificação do genótipo desses locos pela análise de proteínas apresenta a desvantagem de se limitar a fềmeas em lactação, o que restringe sua aplicação em melhoramento. Para a seleção de touros, o genótipo poderia ser inferido a partir do genótipo de suas filhas, mas esse procedimento exigiria um mínimo de cinco anos para que essas entrassem em lactação e tivessem seu genótipo determinado.

Em meados dos anos 80, o polimorfismo dos genes que codificam as proteínas do leite passou a ser investigado pela técnica de RFLP (Rando et al., 1988), permitindo a determinação precoce do genótipo independentemente do sexo. As sequências de muitas dessas proteínas foram determinadas (Threadgill \& Womack, 1990). A א-caseína é composta de 169 aminoácidos. $\mathrm{O}$ alelo $\mathrm{B}$ difere do alelo A por duas mutações de ponto que resultam na substituição do aminoácido isoleucina por treonina na posição 136 , e da alanina por ácido aspártico, na posição 148 da proteína. As duas mutações são reconhecidas pela alteração de sítios de restrição para as enzimas Taq I e Hind III (Lin et al., 1992). A identificação dessas mutações pela técnica de PCR-RFLP foi descrita simultaneamente por Zadwomy \& 
Kuhnlein (1990) e Medrano \& Aguilar-Cordova (1990). Duas outras formas, C e E foram descritas. A forma $\mathrm{C}$ difere da forma $\mathrm{B}$ por uma única substituição de histidina por arginina na posição 97. A forma $\mathrm{E}$ é homóloga à forma $\mathrm{A}$, possuindo uma serina na posição 155 ao invés de glicina (Miranda et al., 1993).

A identificação dos alelos A e B de $\beta$-lactoglobulina pela técnica de PCR-RFLP foi desenvolvida por Medrano \& Aguilar-Cordova (1990) e posteriormente modificada por Ron et al. (1994 b).

Os quatro genes que controlam as caseínas foram caracterizados e atribuídos a uma região de 200 kilobases do cromossomo 6, organizados na seguinte ordem: $\alpha_{s 1}, \beta, \alpha_{s 2}$ e кcaseína (Groenenem \& Poel, 1994). Em virtude da proximidade física no cromossomo, a frequência de recombinação entre esses genes é muito baixa fazendo com que sejam herdados como haplótipos.

As distribuições das variantes genéticas de proteínas do leite são bem conhecidas para diversas raças de bovinos, particularmente nas raças européias. As formas A, B e C de $\alpha_{s 1}$ - caseína são encontradas na raça Holandesa enquanto que nas raças Jersey e Guernsey apenas as formas B e C foram descritas. A variante B é fixada na raça Ayrshire (Lin et al., 1992). Das três variantes genéticas de $\alpha$-lactoalbumina, apenas a forma $B$ foi encontrada em bovinos europeus, sendo as formas A e B encontradas em raças africanas e indianas ( Eigel et al., 1984).

$\mathrm{O}$ alelo $\mathrm{A}$ de $\kappa$-caseína é predominante na raça Holandesa. Van Eenennaam \& Medrano (1991) observaram uma frequência de 0,82 para esse alelo em uma amostra de 1152 animais provenientes de 21 rebanhos da Califormia. Frequência semelhante $(0,87)$ foi observada em touros do rebanho canadense da raça Holandesa (Zadworny \& Kuhnlein, 1990). A frequência observada por Kemenes (1996) em uma amostra do rebanho brasileiro dessa raça foi de 0,81 e, segundo essa autora, a homogeneidade entre os rebanhos dos diferentes países deve-se ao intenso intercâmbio de material genético resultante do uso intensivo de inseminação artificial.

A predominância do alelo A foi também observada em raças zebuínas criadas no Brasil. A frequência em uma amostra de 118 animais da raça Nelore foi de 0,92 e em 83 
animais da raça Gir foi de 0,93 (Kemenes, 1996). Resultados semelhantes foram obtidos por Del Lama \& Zago (1996). O alelo B é predominante nas raças Jersey e Suíça Parda (Van Eenennaam \& Medrano, 1991). A frequência do alelo A nas raças Simmental, Pardo Austríaco e Tirolês Cinza foi de 0,73, 0,36 e 0,54,respectivamente (Schellander et al., 1992).

A frequência do alelo A de $\beta$-lactoglobulina nas raças Holandesa, Suíça Parda , Guernsey, Shorthorn leiteiro e Jersey, estimada por Van Eenennaam \& Medrano (1991), foi de 0,$43 ; 0,39 ; 0,21 ; 0,31$ e 0,37 , respectivamente. A frequência desse alelo no rebanho brasileiro da raça Nelore foi de 0,33 e na raça Gir, 0,37 (Kemenes, 1996).

A variação genética das proteínas do leite influencia as características de processamento desse produto. O leite de animais homozigotos para o alelo B de $\mathrm{k}$-caseína apresentou maior rendimento de queijo, com maior velocidade de coagulação, resultando em um coágulo mais firme do que o leite produzido por animais de genótipo AA para $\kappa$-caseína (Marziali \& Ng-Kwai-Hang, 1986).

$\mathrm{O}$ alelo $\mathrm{B}$ de $\beta$-lactoglobulina foi associado a uma maior concentração de $\mathrm{k}$-caseína. A redução da relação $\beta$-lactoglobulina : $\kappa$-caseína no leite produz um aumento da estabilidade térmica do leite, resultando em um produto mais adequado ao processamento ( Bovenhuis $e t$ al..,1992).

A influência dos polimorfismos genéticos das proteínas do leite sobre características de produção tem sido intensamente investigado. Ng-Kwai-Hang et al..(1984), analisaram a produção de leite na primeira lactação de animais da raça Holandesa no Canadá. $\mathrm{O}$ genótipo de $\alpha_{\mathrm{S1}}$-caseína influenciou significativamente a produção de leite, gordura e proteína. Efeitos significativos sobre a produção de leite e porcentagem de gordura foram também observados para o genótipo de $\beta$ - caseína. A $\kappa$-caseína afetou a concentração de proteína e a proteína total por lactação sendo o teor de proteína nos animais homozigotos para o alelo B 0,13 pontos percentuais superior ao dos animais $\mathrm{AA} \mathrm{O}$ alelo $\mathrm{A}$ de $\beta$-lactoglobulina foi associado à maior concentração de proteína e menor concentração de gordura.

$\mathrm{O}$ efeito de diferentes haplótipos de caseína foi estudado em dez famílias de touros da raça Ayrshire, utilizando o delineamento genético "netas-de-touro" (Velmala et al..,1995). Os haplótipos eram constituídos pelos genótipos de $\alpha_{S 1}$-caseína, $\beta$-caseína, de um 
microssatélite localizado no intron III do gene de $\kappa$-caseína e dos genótipos para $\kappa$-caseína. Esses polimorfismos estão situados dentro de um intervalo de $200 \mathrm{~kb}$, e portanto a recombinação entre eles é negligenciável. $O$ efeito de haplótipo sobre o valor genético dos filhos de touros não foi significativo. Entretanto, a interação haplótipo $\mathrm{x}$ touro foi significativa, tendo sido observada uma grande variação na análise dentro de famílias de touro. Em uma das dez famílias, a diferença entre o valor genético dos filhos que herdaram diferentes haplótipos foi de $430 \mathrm{~kg}$ de leite por lactação e 0,32 pontos percentuais de gordura no leite.

Trabalho semelhante foi conduzido por Lien et al.(1995) em famílias de touro do rebanho norueguês. Efeitos significativos sobre a produção de proteína e de leite foram associados à segregação de um dos haplótipos. $\mathrm{O}$ aumento da produção de proteína associado ao haplótipo favorável nas diferentes familias variou de 0,09 a 0,51 desvios-padrões fenotípicos. Além disso, a genealogia de todos os touros que segregavam para esse haplótipo podia ser traçada a um ancestral comum, um touro de elevado valor genético. Esses resultados sugerem que os efeitos sobre produção são mais provavelmente resultantes da presença de um ou mais $Q T L s$ próximos à região das caseínas.

Os efeitos do polimorfismo de proteínas do leite sobre características de produção de gado de corte são pouco documentados. Em um estudo do efeito de vários marcadores sobre a DEP (Diferença Esperada na Progênie) de pesos à diferentes idades e da produção de leite da mãe na raça Hereford, observou-se uma grande influência do polimorfismo de $\kappa$ caseína sobre características de desempenho. Os efeitos da substituição do alelo A pelo alelo B sobre o DEP para peso ao nascimento, peso à desmama e produção de leite da mãe foram negativos, sugerindo que o alelo A seria favorável para essas características. O efeito de $\kappa$-caseína representou $11 \%$ da variação do peso ao nascer e $14,3 \%$ da produção de leite da mãe (Moody et al., 1994).

\subsubsection{Aplicação dos marcadores no estudo de populações}

Os conceitos de genética de populações foram desenvolvidos a partir de observações experimentais e do desenvolvimento de modelos teóricos (Crow \& Kimura, 
1970). Os marcadores genéticos têm contribuído tanto para o desenvolvimento desses conceitos quanto para a verificação dos modelos propostos.

Do ponto de vista genético, uma população pode ser definida como um conjunto de indivíduos que compartilham seus genes através da reprodução (Falconer, 1989). Durante a formação dos gametas os genótipos dos pais são desfeitos, e apenas os genes passam para a próxima geração, constituindo novas combinações genotípicas durante a formação dos zigotos. Dessa forma, a constrituição genética de uma população pode ser descrita em termos de frequências gênicas para cada loco.

Quando o acasalamento entre os indivíduos da população ocorre ao acaso, a probabilidade de que um indivíduo encontre um parceiro de um dado genótipo é igual à frequência daquele genótipo na população. $\mathrm{O}$ acasalamento ao acaso com respeito às combinações genotípicas equivale à combinação aleatória dos gametas produzidos pela população ( Crow \& Kimura, 1970).

Nessa situação, existe uma relação simples entre as frequências gênicas e genotípicas, constante ao longo das gerações. Essa relação foi demonstrada independentemente por Hardy e Weinberg, em 1908, e é conhecida como princípio de HardyWeinberg. Para exemplificar essa relação, consideremos um único loco com dois alelos, $A_{1} e$ $A_{2}$, com frequências $p_{1}$ e $p_{2}$. A frequência dos genótipos $A_{1} A_{1}, A_{1} A_{2}$ e $A_{2} A_{2}$ resulta da expansão do binômio $\left(p_{1}+p_{2}\right)^{2}$ ou seja, $p_{1}{ }^{2} ; 2 p_{1} p_{2} ; p_{2}{ }^{2}$, respectivamente (Nei, 1987).

O princípio de Hardy-Weinberg limita-se a grandes populações de acasalamento aleatório e pressupõe ausência de seleção, mutação e migração. Entretanto, este princípio é aproximadamente correto para a maioria dos genes nas populações alógamas. Nessas populações, a manutenção das frequências gênicas ao longo das gerações é resultante não da ausência de seleção, mutação e migração, mas do equilibrio entre esses fatores (Crow \& Kimura, 1970).

As restrições impostas ao sistema de acasalamento podem produzir desvios nas proporções genotípicas de uma população. As situações mais frequentes em populações naturais são a ocorrência de endogamia e de cruzamentos preferenciais.

A endogamia resulta do acasalamento entre indivíduos mais aparentados do que se fossem tomados ao acaso da população (Crow \& Kimura, 1970). Quando dois indivíduos 
possuem um ancestral comum podem possuir, para um determinado loco, cópias de um dos genes desse ancestral, denominados alelos "idênticos por descendência". A progênie desses indivíduos frequentemente herdará alelos idênticos de ambos os progenitores. Dessa forma, a consequência imediata da endogamia é o aumento da frequência de genótipos homozigotos resultante do surgimento de indivíduos autozigotos, ou seja, indivíduos que possuem dois alelos "idênticos por descendência" (Falconer, 1989). Entretanto, na ausência de outros fatores, a endogamia não afeta as frequências gênicas.

A magnitude da endogamia é medida pelo coeficiente de endogamia, $F$, que representa a probabilidade de um individuo ser autozigoto para um determinado loco ou a probabilidade de que dois gametas ao acaso da população possuam alelos idênticos por descendência (Crow \& Kimura, 1970).

A frequência com que acasalamentos endogâmicos ocorrem em populações naturais depende do tamanho da população. Em populações pequenas, após poucas gerações de acasalamento, qualquer par de indivíduos será relacionado através de pelo menos um ancestral comum. $\mathrm{O}$ aumento do coeficiente de endogamia de uma geração para outra é de aproximadamente $1 / 2 \mathrm{Ne}$, onde $\mathrm{Ne}$ é o tamanho efetivo da população (Falconer, 1989).

Uma consequência do acúmulo de genótipos homozigotos, decorrente da endogamia, é a expressão de genes recessivos que eram mantidos na condição de heterozigose. Como muitos desses genes são deletérios, a endogamia frequentemente está associada à redução do vigor, da fertilidade e da média das características de produção (Crow \& Kimura, 1970).

Os efeitos da endogamia sobre o desenvolvimento até a desmama, em animais da raça Canchim, foram descritos por Alencar et al. (1981). A média do coeficiente de endogamia foi de $1,85 \%$ para os machos e $1,87 \%$ para as fềmeas. Apesar do reduzido valor, o efeito da endogamia foi significativo para peso aos 205 dias, sendo que os machos foram mais afetados do que as fềmeas.

Barbosa (1991) verificou um efeito significativo da geração da fềmea sobre os pesos da desmama até 24 meses de idade. Esses efeitos foram atribuídos à presença de heterose residual nas fềmeas de gerações menos avançadas. 
As populações naturais e domésticas são geralmente divididas em subpopulações que se mantém parcialmente ou completamente isoladas. Nessas situações, a frequência de homozigotos dentro de cada subpopulação tende a ser maior do que a esperada se o acasalamento ocorresse ao acaso.

Essa propriedade é conhecida como Princípio de Wahlund e pode ser expressa em termos da variância das frequências gênicas entre as subpopulações (Crow \& Kimura, 1970). Nas populações naturais o isolamento pode ser decorrente da distância fisica entre os locais povoados pelas subpopulações e da presença de barreiras geográficas. Nas populações domésticas, resulta geralmente do sistema de melhoramento adotado. Um exemplo é a diferenciação observada entre dois núcleos de criação da raça Friesian sueca. Formada a partir de animais da raça Friesian importados da Holanda, foi mantida como população fechada na província de Halland, tendo sido adotado o esquema de endogamia para obtenção de linhagens. Na província de Scania, a raça permaneceu aberta recebendo constantes introduções de reprodutores holandeses. A comparação das frequências gênicas de antígenos eritrocitários evidenciou diferenças significativas, entre os dois núcleos, em sete dos oito locos analisados (Rendel, 1967).

Três parâmetros foram propostos por Wright para descrever a estrutura das populações: $F_{T T}, F_{\text {IS }}$ e $F_{S T}$. $O$ parâmetro $F_{\Gamma T}$ foi definido por Wright como a correlação entre gametas que se unem para produzir um zigoto, relativa aos gametas da população inteira. $F_{\text {IS }}$ é a módia, entre todas as subpopulações, das correlações entre dois gametas relativa aos gametas dentro de uma subpopulação . Valores positivos de $F_{\mathrm{IS}}$ e $\mathrm{F}_{\mathrm{TT}}$ indicam excesso de homozigotos. Alguns fatores que podem contribuir para o excesso de homozigotos são a seleção contra o heterozigoto, o acasalamento preferencial e a endogamia. A existência de alelos "nulos", que não são detectados no processo de identificação dos genótipos, também pode resultar em deficiência de heterozigotos (Barker et al., 1986). Valores negativos de $\mathrm{F}_{\text {IS }} \mathrm{e}$ $F_{\text {Tr }}$ indicam excesso de heterozigotos, e podem ser observados quando existe prevenção sistemática da endogamia (Wright, 1965). O parâmetro $\mathrm{F}_{\mathrm{ST}}$ foi definido por Wright como a correlação entre os gametas de uma subpopulação e os gametas da população inteira. $\mathrm{O}$ valor de $F_{S T}$ é necessariamente positivo (Wright, 1965) $\mathrm{O}$ coeficiente $\mathrm{F}_{\mathrm{ST}}$ pode ser utilizado 
também para identificar os alelos mais discriminantes entre populações (Ciampolini et al., 1985).

A estimativa desses parâmetros requer a utilização de marcadores uma vez que as frequências gênicas e genotípicas precisam ser conhecidas. Os três parâmetros não são independentes, sendo relacionados pela equação: $1-F_{T T}=\left(1-F_{I S}\right)\left(1-F_{S T}\right)$.

Weir \& Cockerham (1984) propuseram a notação $F$, $\theta$, e f para os parâmetros $F_{I T}, F_{S T}$ e $F_{I S}$, respectivamente. Esses autores propõem a estimativa através de análise de variância, desenvolvendo o conceito para vários alelos e locos.

O processo dispersivo discutido anteriormente, na ausência de outros fatores, não altera as frequências gênicas da população considerada como um todo, ou seja, as médias das frequências entre as subpopulações são iguais às frequências da população base, antes do início do processo dispersivo. A alteração das frequências gênicas ao longo das gerações pode ocorrer em consequência da amostragem dos genes que constituirão a geração seguinte, mesmo em presença de acasalamento ao acaso (Falconer, 1989). Esse processo é denominado deriva genética. A mudança da frequência gênica $(\Delta q)$ nesse caso é aleatória, não sendo possível determinar sua direção . Entretanto, sua magnitude pode ser predita em termos da variância da mudança da frequência, sendo: $\sigma^{2} \Delta q=$ poqo $/ 2 \mathrm{Ne}$.

Observa-se que a dispersão das frequências gênicas entre as amostras é maior em populações pequenas. Esse processo pode chegar ao ponto em que, dentro das amostras cada alelo se encontra fixado ou perdido, dependendo de sua frequência original (Crow \& Kimura, 1970).

Finalmente, a mudança da frequência gênica pode ser decorrente de seleção natural ou artificial. No processo seletivo, a contribuição de um indivíduo para a formação da próxima geração depende de seu valor adaptativo ou valor seletivo.

A mudança decorrente de seleção depende da frequência gênica e da intensidade de seleção (Falconer, 1989). Além disso, o valor seletivo de um genótipo em particular não é necessariamente o mesmo em todos os indivíduos, mas depende da composição genética com relação a outros locos e do ambiente ao qual esse indivíduo deve se adaptar.

Packer (1977), analisando parâmetros genéticos e fenotípicos de bezerros da raça Canchim nascidos entre 1953 e 1973, verificou que os efeitos de ambiente exerceram grande 
influência sobre a mudança fenotípica do crescimento até a desmama. Resultados semelhantes foram obtidos por Freitas (1991) na análise de peso à desmama e aos 365 dias de animais nascidos entre 1982 e 1988, no mesmo rebanho. Nessa situação, a seleção pode ser acompanhada de um efeito de deriva, uma vez que os genes favorecidos em um determinado ciclo de seleção podem ser desfavoráveis no ciclo subsequente, em função da interação genótipo por ambiente.

\subsubsection{Distâncias genéticas}

A comparação entre populações pode atender a objetivos diversos. O grau de diferenciação genética pode elucidar questões sobre a história evolutiva das populações (Nei, 1987). As relações filogenéticas entre raças de bovinos tem merecido grande atenção, principalmente em função de sua importância cultural e de sua estreita ligação com a expansão da espécie humana.

A alta divergência entre as raças pertencentes ao grupo taurino (Bos taumus) e aquelas pertencentes ao grupo zebuíno (Bos indicus), foi ilustrada por Baker \& Manwell (1991).

A análise da evolução do DNA mitocondrial revelou a existência de linhagens mitocondriais exclusivas das raças indianas, sendo as linhagens observadas nas raças zebuínas africanas comuns às raças européias (Loftus et al., 1994). Apesar de surpreendente, em função da semelhança fenotípica entre as raças zebuinas da África e da Ásia, a ausência de linhagens mitocondriais características de zebuínos nas raças Africanas está de acordo com a teoria de origem hibrida dessas raças. De acordo com Bradley et al. (1994), a introdução de genes de zebuínos na África teria ocorrido através dos machos.

No melhoramento animal, as medidas de distância genética podem ser úteis na identificação de cruzamentos mais heteróticos. Cepica et al. (1995), analisando cruzamentos entre raças de suínos, observaram correlações de 0,58 a 0,85 entre a distância genética das raças parentais e a heterozigosidade da geração $F_{1}$. As regressões lineares entre as distâncias genéticas e as três medidas de variabilidade genética foram positivas.

Diversas teorias tem sido propostas para explicar o fenômeno da heterose. Essas teorias foram abordadas em detalhe por Barbosa (1995). Evidências experimentais de 
correlação entre heterozigose e heterose, em animais e plantas foram revisadas por Mitton \& Pierce (1980). Por outro lado, a relação entre distância genética e heterose em bovinos parece ser reforçada pelos resultados obtidos nos cruzamentos entre raças taurinas e zebuínas, nos quais maiores valores de heterose foram observados quando comparados aos cruzamentos entre taurinos ou entre zebuinos (Barbosa, 1995).

O método utilizado para quantificar a distância genética entre as populações depende do objetivo do estudo. Quando o objetivo é avaliar a proximidade entre dois objetos, as medidas de distância geométrica podem ser empregadas. Entre elas, a Distância Euclidiana é a mais utilizada (Weir, 1996). A Distância Euclidiana Média é derivada da Distância Euclidiana pela divisão da soma de quadrados dos desvios das frequências alélicas pelo número de coordenadas envolvidas, fomecendo um melhor parâmetro de comparação entre os resultados obtidos com diferentes números de coordenadas (alelos) (Bussab et al.,1990).

Quando o objetivo é a descrição da história evolutiva das populações, as distâncias que se baseiam em modelos genéticos são mais apropriadas (Weir, 1996). Nesses casos, a medida de distância genética proposta por Nei (1972) é bastante utilizada.

A Distância Standard de Nei é baseada na identidade dos genes nas populações analisadas e fornece uma estimativa do tempo desde a divergência das populações. Essa estimativa é mais precisa para a evolução a longo prazo (Weir, 1996).

A distância genética entre raças zebuínas e tauninas no Brasil tem sido relatada. Del Lama (1991) utilizando a Distância Standard de Nei para 11 marcadores imunológicos e bioquímicos, obteve valores médios de 0,02 entre raças zebuínas. A maior distância estimada nesse estudo foi de 0,24 entre as raças zebuínas e a raça Charolesa. A distância entre a raça Canchim e as raças zebuínas foi em média 0,162 .

As distâncias genéticas entre a raça Charolesa e cinco raças européias foram estimadas por Machugh et al. (1994), utilizando 11 marcadores de DNA microssatélite. O dendrograma obtido a partir dos valores de Distância Standard de Nei posicionou a raça Charolesa como um grupo genético distinto das demais raças européias analisadas (Aberdeen Angus, Jersey, Hereford, Friesian e Simmental). De acordo com esses autores, essa diferenciação pode estar relacionada à história da raça Charolesa, que possivelmente foi formada a partir de animais introduzidos na França pelas legiões romanas. 


\section{MATERIAL E MÉTODOS}

\subsection{Material}

\subsubsection{Animais}

Os bovinos da raça Canchim utilizados nesse estudo pertencem ao rebanho do CPPSE/EMBRAPA, localizado no município de São Carlos, Estado de São Paulo. Esse rebanho vem sendo mantido fechado desde a sua formação. A raça Canchim foi formada pelo cruzamento de animais da raça Charolesa e animais de raças zebuínas de modo a obter uma composição genética média de 5/8 (62,5\%) de genes de Charolês (Bos taurus) e 3/8 (37,5\%) de genes de Zebu (Bos indicus). Por ocasião da coleta de dados, o rebanho era constituído por 558 animais pertencentes a diferentes gerações de acasalamento entre animais 5/8 Charolês $+3 / 8$ Zebu.

Os animais foram classificados de acordo com a geração, calculada pela fórmula de Brinks et al. (1961): GI $=\frac{G P+G M+2}{2}$ onde, GI é o número de geração do indivíduo; GP é o número da geração do pai e GM é o número da geração da mãe

Os animais fundadores ( $5 / 8$ Charolês $+3 / 8 \mathrm{Zebu}$ ) foram considerados geração zero. O valor de GI foi calculado para todos os animais registrados no banco de dados do rebanho Canchim, em um total de 6.320 animais, a fim de se obter o valor de GI para os animais vivos. Essa classificação foi utilizada com a finalidade de analisar a variação temporal das frequências gênicas para os marcadores moleculares. Assim, os animais de gerações menos avançadas devem guardar maior semelhança com a população base, e a medida que as gerações vão avançando, os processos de seleção, endogamia e deriva promovem a diferenciação da população com relação aos fundadores. Por se tratar de uma espécie com gerações sobrepostas, o número de gerações obtidos apresentou uma distribuição contínua. Os animais 
vivos, nascidos no período entre 1981 e 1995, foram então agrupados em classes, dentro das quais as amostras aleatórias foram coletadas, como descrito na Tabela 1. Nessa tabela encontra-se também a porcentagem de fềmeas e machos em cada amostra. A classe $G_{3}$ foi constituída por todos os animais de geração menor ou igual a 3,5 que se encontravam no rebanho por ocasião da coleta de material.

Tabela 1. Classificação da amostra do rebanho Canchim de acordo com a geração.

\begin{tabular}{cccc}
\hline Classe & $\begin{array}{c}\text { Número de animais } \\
\text { amostrados }\end{array}$ & $\begin{array}{c}\text { Fêmeas } \\
\%\end{array}$ & $\begin{array}{c}\text { Machos } \\
\%\end{array}$ \\
\hline $0,0<\mathrm{G} \leq 3,5=\mathrm{G}_{3}$ & 24 & 87 & 13 \\
$3,5<\mathrm{G} \leq 4,5=\mathrm{G}_{4}$ & 41 & 75 & 25 \\
$4,5<\mathrm{G} \leq 5,5=\mathrm{G}_{5}$ & 48 & 56 & 44 \\
$5,5<\mathrm{G} \leq 6,5=\mathrm{G}_{6}$ & 41 & 51 & 49 \\
\hline Total & 154 & 62 & 38 \\
\hline
\end{tabular}

A amostra de animais da raça Charolesa foi composta por 24 touros pertencentes a três centrais de inseminação (Genética Avançada, Lagoa da Serra e Pecplan - Bradesco). Esses touros eram provenientes de quatro países (Argentina, Brasil, Canadá e França). Também foram utilizados 12 animais pertencentes à Fazenda Modelo do Instituto Agronômico do Paraná (IAPAR), localizada em Ponta Grossa Paraná, totalizando 36 animais. Esses animais foram incluídos no estudo com o objetivo de comparar as frequências gênicas das diferentes gerações de Canchim com as frequências de representantes de uma das raças parentais. 


\subsubsection{Marcadores}

Sete marcadores de DNA foram analisados neste trabalho. Esses marcadores pertenciam a duas categorias: polimorfismos de tamanho de fragmentos de restrição (RFLP) e polimorfismos de número de repetições de dinucleotídeos (microssatélites). Os dois tipos de marcadores foram analisados pela técnica de PCR. Os locos foram selecionados para representar diferentes cromossomos e, com excessão do microssatélite BM1224, todos os locos analisados são candidatos à associação com características de produção. As localizações desses marcadores no mapa genético dos bovinos bem como a descrição dos oligonucleotídeos utilizados para a amplificação são apresentados na Tabela 2.

\subsubsection{Reagentes}

Todos os reagentes utilizados foram de qualidade própria para Biologia Molecular. As soluções aquosas foram preparadas com água ultra pura, microfiltrada. As enzimas de restrição, Taq DNApolimerase e reagentes para PCR foram das marcas Gibco BRL e Pharmacia. Reagentes adquiridos de outros fabricantes são especificados no texto. Os oligonucleotídeos foram sintetizados pela National Biosciences, Inc. . 


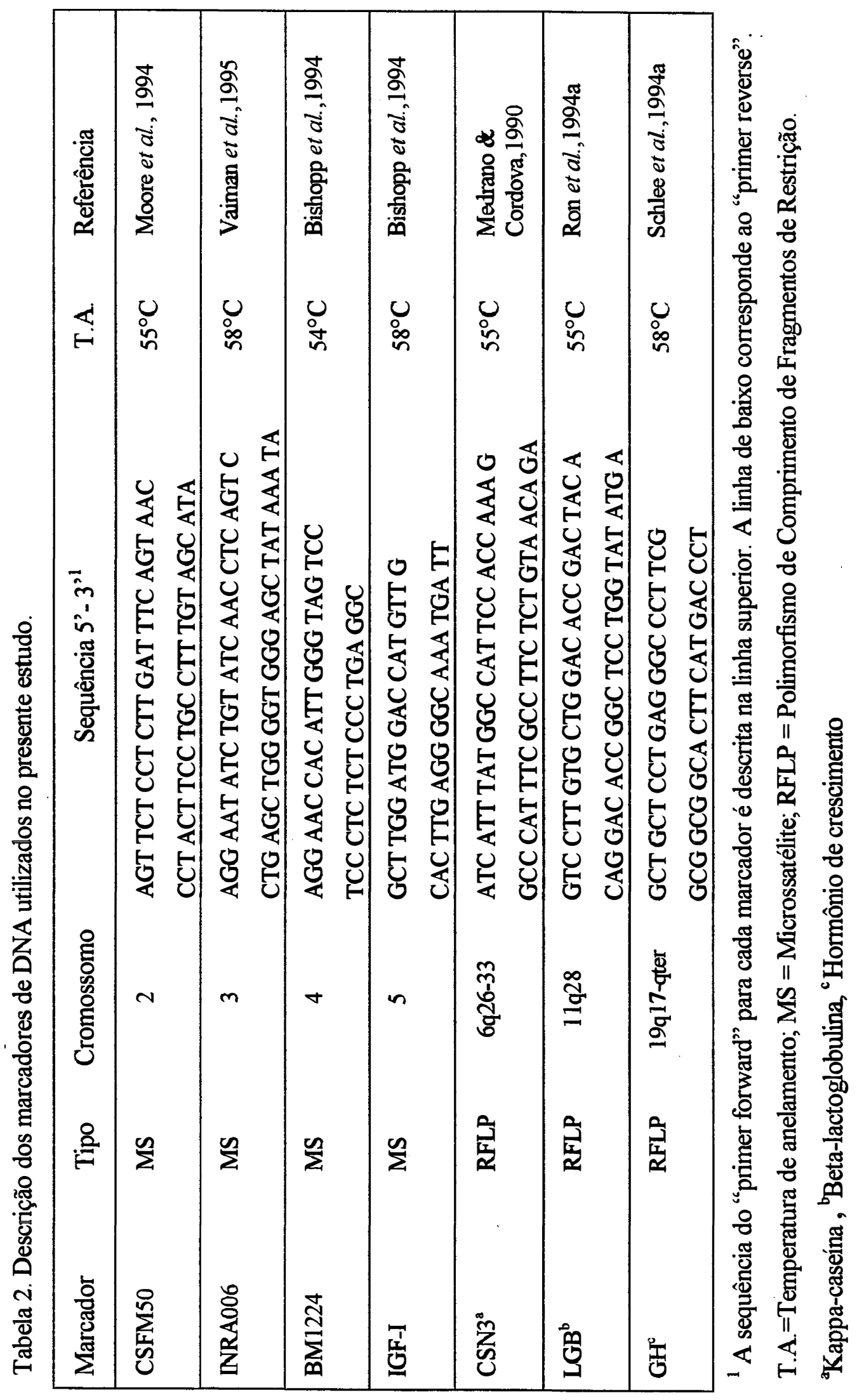




\subsection{Métodos}

\subsubsection{Extração de DNA de amostras de sangue}

Amostras de sangue foram obtidas por punção da jugular em tubos para coleta à vácuo, contendo EDTA como anti-coagulante. As células foram rompidas em presença de sucrose $0,32 \mathrm{M}$, Tris- $\mathrm{HCl} 10 \mathrm{mM}(\mathrm{pH} 7,5), \mathrm{MgCl}_{2} 5 \mathrm{mM}$ e $1 \%$ de triton X-100 e centrifugadas a $13.000 \mathrm{~g}$ por 20 segundos. $\mathrm{O}$ processo foi repetido três vezes até a obtenção de um sedimento branco. O sedimento foi então ressuspendido em $500 \mu \mathrm{l}$ de solução contendo $50 \mathrm{mM} \mathrm{KCl}, 10 \mathrm{mM}$ Tris- $\mathrm{HCl}(\mathrm{pH} 8,3), 1,5 \mathrm{mM} \mathrm{MgCl}_{2}, 1 \%$ de triton X-100 e 60 ng de proteinase $\mathrm{K}$ por microlitro. A suspensão foi incubada por 1 hora a $50{ }^{\circ} \mathrm{C}$. Após este período a proteinase $\mathrm{K}$ foi inativada a $95^{\circ} \mathrm{C}$ por 10 minutos e o material foi armazenado a -20 ${ }^{\circ} \mathrm{C}$ até o momento do uso.

A concentração das preparações de DNA foi estimada por fluorimetria em aparelho DyNA Quant 200 (Hoefer). Para tanto, $2 \mu \mathrm{l}$ de amostra foram adicionados a $2 \mathrm{ml}$ de uma solução contendo $100 \mathrm{mM}$ Tris pH 7,5; $50 \mathrm{mM}$ EDTA pH 8,0; $200 \mathrm{mM}$ $\mathrm{NaCl}$ e $0,1 \%$ de corante fluorescente $\mathrm{H} 33258$. Esta solução foi preparada no momento do uso. A leitura da concentração de DNA foi realizada após homogeneização da mistura acima. A quantidade de DNA obtida utilizando-se este procedimento variou de 20 a $40 \mu$ de DNA por mililitro de sangue.

\subsubsection{Extração de DNA de amostras de sêmen}

O DNA foi extraído a partir de uma a duas palhetas de sêmen por animal. O método utilizado foi o descrito por Zadworny \& Kuhnlein (1990), modificado pela substituição da desproteinização com fenol por precipitação das proteínas em presença de alta concentração de sal.

Cada palheta de sêmen foi centrifugada a $16.000 \times \mathrm{g}$ por 10 minutos em tubo para microcentrífuga. $\mathrm{O}$ sobrenadante foi descartado e o sedimento foi ressuspendido em $1 \mathrm{ml}$ de PBS ( $2,7 \mathrm{mM} \mathrm{KCl} ; 1,5 \mathrm{mM} \mathrm{KH}_{2} \mathrm{PO}_{4} ; 137 \mathrm{mM} \mathrm{NaCl} ; 8 \mathrm{mM} \mathrm{Na}_{2} \mathrm{HPO}_{4} ; \mathrm{pH} 7,0$ ) e centrifugado a $16.000 \times \mathrm{g}$ por 5 minutos. Este procedimento foi realizado quatro vezes, para a obtenção de um sedimento livre de diluentes e crioprotetores. $O$ sedimento foi 
ressuspendido em $100 \mu \mathrm{l}$ de PBS e $400 \mu \mathrm{l}$ de solução de lise ( 2\% de 2-mercaptoetanol; $10 \mathrm{mM}$ TrisHCl pH 8,0;100 mM NaCl; $10 \mathrm{mM}$ EDTA pH 8,0;0,5\% de SDS) e incubado a $50{ }^{\circ} \mathrm{C}$ por 30 minutos. Adicionou-se Proteinase $\mathrm{K}$ a uma concentração final de $200 \mu \mathrm{g} / \mathrm{ml} \mathrm{e}$ incubou-se por mais 16 horas a $50^{\circ} \mathrm{C}$.

As proteínas foram precipitadas pela adição de $\mathrm{NaCl}$ a uma concentração final de $1,0 \mathrm{M}$ e centrifugação a $16.000 \times \mathrm{g}$ por 5 minutos. $\mathrm{O}$ sobrenadante foi recuperado e o DNA foi precipitado pela adição de dois volumes de etanol absoluto. Após centrifugação a $16.000 \times$ g por 10 minutos, descartou-se o etanol. O sedimento de DNA foi secado ao ar e ressuspendido em $100 \mu l$ de água ultra pura.

A concentração da suspensão de DNA foi estimada por fluorimetria em aparelho DyNAQuant 200 (Hoefer), como descrito no ítem anterior. A quantidade de DNA obtida por palheta de sêmen variou de 10 a $100 \mu \mathrm{g}$. Essa variação é decorrente da diluição utilizada no processamento do sêmen, em função das características fisicas do sêmen.

\subsubsection{Identificação dos genótipos de kappa-caseína}

Uma região de 350 pares de base do gene da $\mathrm{k}$-caseína, localizada entre os nucleotídeos 201 do exon IV e 149 do intron IV, foi amplificada com os "primers" descritos por Medrano \& Cordova (1990). Essa região contém as mutações de ponto que resultam na substituição do aminoácido isoleucina por treonina, na posição 136, e da alanina por ácido aspártico, na posição 148 da proteína. As duas mutações são reconhecidas pela alteração de sítios de restrição para as enzimas Taq I e Hind III.

\subsubsection{Amplificação}

As reações de amplificação foram conduzidas em aparelho termociclador modelo PTC-100 (MJ Research Inc., USA), em tubos de microcentrífuga. Cada reação foi constituída de aproximadamente $100 \mathrm{ng}$ de DNA em solução de PCR (20 mM Tris$\mathrm{HCl}, \mathrm{pH} 8,4 ; 50 \mathrm{mM} \mathrm{KCl}$ ) acrescida de $1,5 \mathrm{mM} \mathrm{MgCl}_{2}, 200 \mathrm{nM}$ de cada dNTP, $400 \mathrm{nM}$ de cada um dos "primers" indicados na tabela 1 e 0,5 unidades de Taq DNA polimerase, 
em um volume final de $25 \mu$. Aproximadamente $30 \mu \mathrm{l}$ de óleo de silicone foram acrescentados para evitar a evaporação. A reação de PCR constou de uma desnaturação inicial de 3 minutos a $94^{\circ} \mathrm{C}$ seguida de 30 ciclos de amplificação, sendo cada ciclo de 45 segundos a $94^{\circ} \mathrm{C}, 1$ minuto a $55^{\circ} \mathrm{C}$ e 1 minuto e 15 segundos a $73^{\circ} \mathrm{C}$.

\subsubsection{Análise de restrição}

Os produtos de amplificação foram digeridos com a enzima de restrição Hinfı por três horas a $37^{\circ} \mathrm{C}$. Em cada reação foram utilizados $10 \mu$ de produto de PCR, 2,5 unidades de Hinfl, $50 \mathrm{mM}$ Tris- $\mathrm{HCl}$ (pH 8,0), $10 \mathrm{mM} \mathrm{MgCl}_{2}$ e $50 \mathrm{mM} \mathrm{NaCl}$, em um volume final de $13 \mu \mathrm{l}$. Os fragmentos resultantes foram separados em géis de agarose de baixo ponto de fusão a 3\%, preparados de acordo com Sambrook et al.(1989). A eletroforese foi realizada em tampão Tris-borato-EDTA a $5 \mathrm{~V} / \mathrm{cm}$.

Após a eletroforese o gel foi corado em solução de brometo de etídio a 0,5 $\mathrm{mg} / \mathrm{ml}$ e fotografado sob luz ultra-violeta. O padrão de tamanho de DNA dupla fita $\phi \mathrm{X} 174$ - Hae III foi utilizado em cada gel para permitir o cálculo do tamanho dos fragmentos.

\subsubsection{Análise de $\beta$-lactoglobulina}

\subsubsection{Amplificação}

Os "primers" descritos por Ron et al. (1994a), cuja sequência é apresentada na tabela 1, foram utilizados para amplificar uma região de 262 pb localizada entre os nucleotídeos 18 do exon IV e 168 do intron IV do gene da $\beta$-lactoglobulina.

Em cada reação de amplificação foram usados 100 ng de DNA, 20 mM Tris$\mathrm{HCl}(\mathrm{pH} \mathrm{8,4),} 50 \mathrm{mM} \mathrm{KCl}, 1,5 \mathrm{mM} \mathrm{MgCl}$, 0,2 mM de cada dNTP, $300 \mathrm{nM}$ de cada "primer" e 0,5 unidades de Taq DNA polimerase em um volume de $25 \mu \mathrm{l}$. 
Os ciclos de amplificação descritos por Ron et al. (1994a) foram alterados para melhorar a fidelidade e o rendimento da amplificação como descrito a seguir:

$1^{\circ}$ ciclo: - desnaturação a $94^{\circ} \mathrm{C}$ por 3 minutos;

- anelamento a $64^{\circ} \mathrm{C}$ por 1 minuto;

- extensão a $72{ }^{\circ} \mathrm{C}$ por 40 segundos;

$2^{\circ}$ ciclo: - desnaturação a $94^{\circ} \mathrm{C}$ por 1 minuto;

- anelamento a $63^{\circ} \mathrm{C}$ por 1 minuto;

- extensão a $72{ }^{\circ} \mathrm{C}$ por 40 segundos;

$3^{\circ}$ ciclo: - desnaturação a $94^{\circ} \mathrm{C}$ por 1 minuto;

- anelamento a $62^{\circ} \mathrm{C}$ por 1 minuto;

- extensão a $72^{\circ} \mathrm{C}$ por 40 segundos;

$4^{\circ}$ ciclo: - desnaturação a $94^{\circ} \mathrm{C}$ por 1 minuto;

- anelamento a $61^{\circ} \mathrm{C}$ por 1 minuto;

- extensão a $72^{\circ} \mathrm{C}$ por 40 segundos;

30 ciclos de: - desnaturação a $94^{\circ} \mathrm{C}$ por 1 minuto;

- anelamento a $60^{\circ} \mathrm{C}$ por 1 minuto;

- extensão a $72^{\circ} \mathrm{C}$ por 40 segundos;

e uma extensão final de 4 minutos a $72^{\circ} \mathrm{C}$.

\subsubsection{Análise de restrição}

$5 \mu$ de DNA amplificado foram digeridos com 2 unidades da enzima de restrição HaeIII em solução contendo $50 \mathrm{mM}$ Tris- $\mathrm{HCl}, 10 \mathrm{mM} \mathrm{MgCl}$, $50 \mathrm{mM} \mathrm{NaCl}$ por um período de 4 horas a $37^{\circ} \mathrm{C}$. Os produtos de digestão foram separados em géis de agarose de baixo ponto de fusão a $3 \%$, corados e fotografados como descrito anteriormente (item 3.2.3.2). 


\subsubsection{Identificação dos genótipos de hormônio de crescimento}

\subsubsection{Amplificação}

Os "primers" descritos na tabela 1 foram utilizados para amplificar uma sequência de $223 \mathrm{pb}$, localizada entre o intron IV e o exon V do gene do hormônio de crescimento (Schlee et al., 1994a).

As reações de PCR continham 100 ng de DNA, 20 mM Tris- $\mathrm{HCl}, \mathrm{pH} \mathrm{8,4;50}$ $\mathrm{mM} \mathrm{KCl}, 1,5 \mathrm{mM} \mathrm{MgCl} 2,0,2 \mathrm{mM}$ de cada dNTP, $400 \mathrm{nM}$ de cada primer e 0,5 unidades de Taq DNA polimerase em um volume de $25 \mu$ l. A reação de PCR constou de uma desnaturação inicial de 4 minutos a $94^{\circ} \mathrm{C}$ seguida de 35 ciclos de desnaturação a $94{ }^{\circ} \mathrm{C}$ por 1 minuto, anelamento a $58^{\circ} \mathrm{C}$ por 1 minuto e extensão a $72^{\circ} \mathrm{C}$ por 1 minuto. Ao final desses ciclos foi realizada uma extensão final de 4 minutos a $72{ }^{\circ} \mathrm{C}$.

\subsubsection{Análise de restrição}

A digestão dos produtos de restrição foi feita em um volume final de $11 \mu \mathrm{l}$ contendo $4 \mu$ l de DNA amplificado, $10 \mathrm{mM}$ Tris-acetato (pH 7,5), $10 \mathrm{mM}$ acetato de magnésio, $50 \mathrm{mM}$ acetato de potássio, e 2 unidades da enzima $A l u I$. A reação de digestão foi incubada a $37^{\circ} \mathrm{C}$ por 4 horas.

Os fragmentos foram separados em gel de agarose de baixo ponto de fusão a $3 \%$, corados e fotografados como descrito anteriormente (item 3.2.3.2).

\subsubsection{Análise de marcadores de DNA microssatélite}

\subsubsection{Marcação dos oligonucleotídeos iniciadores}

Os oligonucleotídeos complementares à fita anti-sense, também denominados "primers forward", foram marcados pela adição de $\left[\gamma^{32} \mathrm{P}\right]$ à extremidade 5 '. A reação de marcação foi catalizada pela enzima polinucleotideoquinase de bacteriófago T4. Esta enzima utiliza um ATP como doador de grupamento gama-fosfato e promove a fosforilação específica da hidroxila da extremidade 5'do DNA ou RNA. No caso de oligonucleotídeos sintéticos não há necessidade de um tratamento prévio do DNA com fosfatase alcalina, uma vez que a extremidade a ser marcada não apresenta grupamento 
fosfato. Em cada reação de marcação, 200 pmol de oligonucleotídeos foram incubados a $37{ }^{\circ} \mathrm{C}$ em presença de $20 \mu \mathrm{Ci}$ de $\left[\gamma^{32} \mathrm{P}\right]$-ATP, a uma atividade de $3.000 \mathrm{Ci}$ por milimol (Amershan), $50 \mathrm{mM}$ Tris- $\mathrm{HCl}(\mathrm{pH} 7,6), 10 \mathrm{mM} \mathrm{MgCl}, 10 \mathrm{mM}$ 2-mercaptoetanol e 3 unidades de T4 - polinucleotideo quinase (Amershan). A reação foi interrompida por aquecimento a $65{ }^{\circ} \mathrm{C}$ por 5 minutos e os "primers" foram mantidos a $4{ }^{\circ} \mathrm{C}$ até o momento do uso.

\subsubsection{Marcação do padrão de tamanho}

Um padrão de tamanho com fragmentos a intervalos de $10 \mathrm{pb}$, foi utilizado para a determinação do tamanho dos alelos em cada loco microssatélite. Esse padrão foi marcado na extremidade 5' em reações de troca de grupamento fosfato catalisada pela T4 - polinucleotideo quinase explorando a reversibilidade da reação catalisada por essa enzima, ou seja, a transferência de grupamentos fosfato da extremidade a ser marcada para o ADP.

Foram utilizados 340 ng de padrão de DNA em reações de $50 \mu$ contendo 8 a 10 unidades de T4 - polinucleotideo quinase (Ready-to-go ${ }^{\mathrm{TM}}$, Pharmacia), $50 \mathrm{mM}$ Tris$\mathrm{HCl}\left(\mathrm{pH} \mathrm{7,6),} 10 \mathrm{mM} \mathrm{MgCl}_{2}, 5 \mathrm{mM}\right.$ ditiotreitol, 0,1 mM EDTA (pH 8,0), 0,2 $\mu \mathrm{M}$ ADP e $20 \mu \mathrm{Ci}$ de $\left[\gamma^{32} \mathrm{P}\right]$-ATP (Amershan). Após uma hora de incubação a $37{ }^{\circ} \mathrm{C}$, as reações foram interrompidas pela adição de EDTA a uma concentração final de 25 $\mathrm{mM}$.

\subsubsection{Amplificação de microssatélites}

Os marcadores foram amplificados em um volume de reação de $25 \mu$, contendo 100 ng de DNA, $50 \mathrm{mM} \mathrm{KCl}, 1,5 \mathrm{mM} \mathrm{MgCl}, 20 \mathrm{mM}$ Tris- $\mathrm{HCl}(\mathrm{pH} 8,4), 0,2 \mu \mathrm{M}$ de cada dNTP, 0,5 unidades de Taq DNA polimerase e 0,16 $\mu \mathrm{M}$ de cada "primer", sendo o "primer forward" marcado com ${ }^{32} \mathrm{P}$. As reações de amplificação incluíram desnaturação inicial de $94{ }^{\circ} \mathrm{C}$ por 2 minutos, seguida de 30 ciclos de: desnaturação a $94{ }^{\circ} \mathrm{C}$ por 1 minuto, anelamento por 30 segundos na temperatura adequada para cada loco (tabela 1) 
e extensão a $72{ }^{\circ} \mathrm{C}$ por 1 minuto. Ao final desses ciclos foi realizada uma extensão final a $72^{\circ} \mathrm{C}$ por 4 minutos. Esse procedimento foi realizado em aparelho termociclador PTC100, para tubos de microcentrifuga, e em aparelho PTC-200, para placas de 96 amostras (MJ Research Inc., USA).

\subsubsection{Resolução dos marcadores de DNA microssatélite}

A separação dos produtos de amplificação de locos microssatélites foi realizada em géis de poliacrilamida desnaturante de modo a permitir a separação por tamanho de fragmentos que diferiam em apenas $2 \mathrm{pb}$ e evitar o aparecimento de polimorfismos resultantes da conformação das moléculas.

Os géis de poliacrilamida foram preparados com 6,67\% de solução de acrilamida (29 acrilamida : 1 bisacrilamida), em 1,2X TBE modificado ( $120 \mathrm{mM}$ Tris, $12 \mathrm{mM}$ ácido bórico , $1 \mathrm{mM}$ EDTA, Davis ${ }^{4}$ ) acrescido de 9,5 $\mathrm{M}$ de uréia, 3,8 $\mathrm{mM}$ de TEMED e 2,5 mM de persulfato de amônia. A polimerização foi feita em moldes de vidro de 30 X 40 centímetros, de acordo com Sambrook et al.(1989).

Após a adição do tampão para amostra de gel desnaturante ( $95 \%$ formamida, $20 \mathrm{mM}$ EDTA pH 7,5 a 8,0,0,05\% chileno-cianol e 0,05\% azul de bromofenol) na proporção de $2: 3$, as amostras de PCR foram desnaturadas a $90{ }^{\circ} \mathrm{C}$ por 15 minutos e aplicadas no gel. Em todos os géis o padrão de tamanho de fragmentos a intervalos de 10 pb e padrões de alelos conhecidos foram utilizados. As eletrofores foram realizadas a uma potência de $50 \mathrm{~W}$ por 3 a 5 horas, de acordo com o tamanho do produto de amplificação. A estimativa do tempo de migração necessário para a separação dos alelos foi feita com base na migração do corante chileno-cianol que, nessas condições, apresenta uma taxa de migração semelhante a fragmentos de DNA de 106 pb.

Após a eletroforese, o segmento do gel que continha os produtos de amplificação foi localizado com um detector de radiação e uma tira de papel filtro foi

\footnotetext{
4 Davis, S. Animal Science Department, Texas A\&M University, College Station, USA. Informação pessoal, 1995.
} 
aderida à essa porção do gel, de maneira a permitir sua remoção do molde de vidro. $\mathrm{O}$ segmento do gel aderido ao papel filtro foi coberto com um filme de PVC e desidratado em secador de gel modelo SGD 2.000 (Savant), a $80^{\circ} \mathrm{C}$ e pressão negativa de $625 \mathrm{~mm}$ Hg por 1 hora.

As autorradiografias foram realizadas a temperatura ambiente em filmes Hyperfilm $^{\text {TM }}$-MP (Amershan) e filmes RX (Fuji), com ou sem ecran. O tempo de exposição do filme foi calculado com base na radioatividade medida com o contador Geiger. Esse tempo variou de 24 a 120 horas correspondendo a atividades de 20 cps e 5 cps, respectivamente. Na ausência de ecran, o tempo de exposição foi o dobro.

Após a exposição, os filmes foram revelados por 3 minutos em solução reveladora-reforçadora Kodak GBX, lavados por 20 segundos em água, fixados em solução fixadora-reforçadora Kodak GBX e lavados em água corrente por 15 minutos.

As distâncias percorridas pelos fragmentos do padrão e pelos alelos de microssatélites foram medidas com régua.

\subsubsection{Métodos estatísticos}

\subsubsection{Estimativa do tamanho dos alelos de microssatélite}

As distâncias percorridas pelos fragmentos de tamanho conhecido do padrão foram utilizadas para definir a função logarítmica entre a distância percorrida e o tamanho do DNA para cada eletroforese. As equações obtidas foram utilizadas para calcular o tamanho dos alelos observados em cada loco.

Com a finalidade de facilitar a identificação dos genótipos e o processamento dos dados, os alelos de cada loco foram numerados em ordem decrescente de tamanho, respeitando-se os intervalos de 2 pares de bases. Assim, o alelo de maior tamanho em um determinado loco foi denominado alelo 1. Se o próximo alelo observado apresentou 4 pares de bases a menos, foi denominado alelo 3 e assim sucessivamente. Essa metodologia foi adotada para evitar a utilização de índices para novos alelos que surgissem em um intervalo já observado. Números negativos foram utilizados para alelos 
maiores do que o alelo 1. Por exemplo, o número -1 corresponde ao alelo com 2 pares de bases a mais do que o alelo 1 .

\subsubsection{Estimativa das frequências genotípicas}

As frequências genotípicas em cada amostra foram estimadas pela contagem dos diferentes genótipos, de acordo com Weir (1996). A frequência estimada para cada combinação de alelos, $\hat{P} u v$, foi dada pela equação:

$$
\hat{\mathrm{P}}_{\mathbf{u v}}=\frac{\mathrm{Nuv}}{\mathrm{N}}
$$

onde: $\mathrm{N}_{\mathrm{uv}}$ é o número de animais observados para essa combinação e $\mathrm{N}$ é o tamanho da amostra.

\subsubsection{Estimativa das frequências gênicas}

As freqüências gênicas em cada loco foram calculadas por contagem gênica, de acordo com Weir (1996). A frequência de um alelo pode ser definida por:

$$
\hat{p}_{u}=\frac{2 N u u+\sum_{u \neq v} N u v}{2 N}
$$

onde:

$\mathrm{N}_{\mathrm{uu}}=$ número de indivíduos homozigotos para o alelo $\mathrm{A}_{\mathrm{u}}$;

$\mathrm{N}_{\mathrm{uv}}=$ número de indivíduos heterozigotos para esse alelo; $\mathrm{N}=$ tamanho da amostra.

Os erros padrões das estimativas de frequências gênicas foram calculados por: 


$$
E P=\sqrt{\frac{p_{u}\left(1-p_{u}\right)}{2 N}}
$$

onde: $p_{u}=$ frequência do alelo $A_{u}$;

$\mathrm{N}=$ tamanho da amostra.

\subsubsection{Hipótese de Hardy-Weinberg}

$\mathrm{O}$ teste de aderência às proporções genotípicas esperadas sob a hipótese de equilibrio de Hardy-Weinberg foi feito individualmente para cada amostra de um determinado loco, pelo método do Qui-quadrado. O número de animais esperados em cada classe genotípica foi calculado a partir das frequências gênicas estimadas. Nos marcadores em que a frequência de alguns alelos foi muito baixa, as classes genotípicas menos representadas foram agrupadas como proposto por Barker et al. (1986), para evitar a ocorrência de valores esperados inferiores a 5 .

Os valores de qui-quadrado foram obtidos pela fórmula:

$$
\chi^{2}=\sum\left[\left[\frac{\mathrm{N}_{\mathrm{o}}-\mathrm{N}_{\mathrm{e}}}{\mathrm{N}_{\mathrm{e}}}\right)^{2}\right]
$$

onde: $\mathrm{N}_{\mathrm{o}}=$ número de animais observados na classe genotípica;

$\mathrm{N}_{\mathrm{e}}=$ número de animais esperados com base nas frequências gênicas.

Os valores foram comparados com os valores tabelados para os graus de liberdade correspondentes. Os graus de liberdade em cada teste foram dados pelo número de classas genotípicas, menos o número de parâmetros necessários para o cálculo de $\mathrm{N}_{\mathrm{e}}$, menos 1 . 
Nos locos com dois alelos em que as frequências esperadas foram menores do que 1 e as frequências observadas menores do que 5, a probabilidade exata de se obter ao acaso uma amostra como a observada foi calculada de acordo com Weir (1996). A probabilidade de se obter um determinado número de indivíduos heterozigotos em uma amostra é dada por:

$$
\operatorname{Pr}\left(\mathrm{x} \mid \mathrm{n}_{\mathrm{A}}\right)=\frac{\mathrm{n} ! \mathrm{n}_{\mathrm{A}} !\left(2 \mathrm{n}-\mathrm{n}_{\mathrm{A}}\right) ! 2^{\mathrm{x}}}{\left[\left(\mathrm{n}_{\mathrm{A}}-\mathrm{x}\right) / 2\right] ! \mathrm{x} !\left[\mathrm{n}-\left(\mathrm{n}_{\mathrm{A}}+\mathrm{x}\right) / 2\right] !(2 \mathrm{n}) !}
$$

onde: $\mathrm{n}_{\mathrm{A}}=$ total de alelos $\mathrm{A}$;

$\mathrm{n}=$ número de genes amostrados; $\mathrm{x}=$ número de heterozigotos.

\subsubsection{Teste de Independência das frequências gênicas}

Com a finalidade de testar a significância da variação das frequências gênicas entre as gerações, o teste de independência para tabelas de contingência foi utilizado. As tabelas constaram de duas colunas, representando o total de um alelo e o total do alelo altemativo. Nos locos com mais de dois alelos, cada alelo foi testado contra o total dos alelos altemativos. Em todas as tabelas o número de linhas foi igual ao número de gerações (4). $O$ valor de $\chi^{2}$ foi obtido de acordo com Steel \& Torrie (1960):

$$
\chi^{2}=\frac{\sum \mathrm{n}_{\mathrm{i}}\left(\mathrm{p}_{\mathrm{i}}-\overline{\mathrm{p}}\right)^{2}}{\overline{\mathrm{pq}}}
$$

onde: $n_{i}=$ total de genes analisados na amostra $i$;

$$
p_{i}=\text { frequência do alelo } A_{u} \text {; }
$$

$\bar{p} \bar{q}=$ frequência média dos alelos $A_{u}$ e alelos diferentes de $A_{u}$. 
Os valores obtidos foram comparados com os valores tabelados para $\mathrm{GL}=($ linhas -1$)($ colunas -1$)$. Nos casos em que o valor obtido nessa análise foi significativo, o valor de $\chi^{2}$ foi decomposto em um componente de rgressão linear e um componente de desvios da regressão, de acordo com Snedecor \& Cochran (1967):

O coeficiente de regressão foi dado por:

$$
\mathrm{b}=\frac{\sum \mathrm{a}_{\mathrm{i}} \mathrm{x}_{\mathrm{i}}-\left(\sum \mathrm{a}_{\mathrm{i}}\right)\left(\sum \mathrm{n}_{\mathrm{i}} \mathrm{x}_{\mathrm{i}}\right) / \mathrm{N}}{\sum \mathrm{n}_{\mathrm{i}} \mathrm{x}_{\mathrm{i}}^{2}-\left(\sum \mathrm{n}_{\mathrm{i}} \mathrm{x}_{\mathrm{i}}\right)^{2}}
$$

onde: $a_{i}=$ total do alelo $A_{u}$ na amostra $i$;

$\mathrm{x}_{\mathrm{i}}=$ escore atribuído à amostra $\mathrm{i}\left(1,2,3\right.$ e 4 para as gerações $\mathrm{G}_{3}$ a

$\mathrm{G}_{6}$, respectivamente);

$n_{i}=$ número de genes analisados na amostra $\mathrm{i}$;

$\mathrm{N}=$ total de genes analisados.

Para obter o valor de $\chi^{2}$ da regressão, o desvio-padrão da estimativa de $b$ foi utilizado para obter o valor de $Z$, sob a hipótese de $b=0$. $O$ valor de $Z$ foi então elevado ao quadrado, assumindo que o quadrado de um desvio da distribuição apresenta uma distribuição de $\chi^{2}$ com 1 grau de liberdade (Snedecor \& Cochran, 1967).

$O$ valor de $\chi^{2}$ dos desvios foi dado pela diferença: $\chi_{\text {total }}^{2} \chi^{2}$ regersesio, com graus de liberdade dados por : GL = Número de Gerações -1 .

\subsubsection{Estimativa da heterozigosidade}

A heterozigosidade $(\mathrm{H})$ é uma medida da variabilidade genética das populações e reflete a quantidade de heterozigotos para um determinado loco ou para todos os locos analisados. Em cada loco com $k$ alelos, a heterozigosidade foi estimada por: 


$$
\hat{H}_{l}=\sum_{u \neq l} P_{l u v}
$$

onde:

$P_{\text {luv }}=$ frequência de heterozigotos observados para o loco 1 .

Considerando-se todos os locos simultaneamente obtém-se o valor de heterozigosidade média $(\overline{\hat{H}})$ :

$$
\overline{\hat{\mathrm{H}}}=\frac{1}{\mathrm{~m}} \sum_{1=1}^{\mathrm{m}} \hat{\mathrm{H}}_{1}
$$

onde:

$\mathrm{m}=$ número de locos considerados.

\subsubsection{Diversidade gênica}

A diversidade gênica (D) é outra medida de variabilidade. Essa medida não se refere apenas aos heterozigotos mas ao número de alelos distintos mantidos na população. Para cada loco, a diversidade foi estimada por:

$$
\hat{D}_{1}=1-\sum_{u} p_{1 u}^{2}
$$

onde:

$\mathrm{p}_{\mathrm{lu}}^{2}=$ frequência dos genótipos homozigotos para o alelo $A_{u}$ no loco 1 .

Considerando todos os locos em conjunto, a diversidade média foi dada por:

$$
\overline{\mathrm{D}}=1-\frac{1}{\mathrm{~m}} \sum_{\mathrm{l}=1}^{\mathrm{m}} \sum_{\mathrm{u}} \mathrm{p}_{\mathrm{lu}}^{2}
$$

onde:

$\mathrm{m}=$ número de locos. 


\subsubsection{Estatística F}

Para identificar as causas das disperssões das frequências, os desvios das proporções genotípicas para cada loco nas diferentes gerações de Canchim foram definidos em termos de três parâmetros: $\mathrm{F}_{\mathrm{IS}}, \mathrm{F}_{\mathrm{IT}}$ e $\mathrm{F}_{\mathrm{ST}}$, denominados índices de fixação.

$O$ índice $F_{T T}$ estima a probabilidade de que dois gametas da população sejam idênticos por descendência. $F_{I S}$ é a probabilidade de que dois gametas de uma subpopulação sejam idênticos por descendência e $F_{S T}$ é a correlação entre dois gametas retirados ao acaso de cada uma das subpopulações. Este último pode ser utilizado como uma medida da diferenciação genética das subpopulações, no presente estudo, representadas por gerações. Os três coeficientes são relacionados pela seguinte equação:

$$
\left(1-F_{I T}\right)=\left(1-F_{\mathrm{IS}}\right)\left(1-\mathrm{F}_{\mathrm{ST}}\right)
$$

O programa de computador Biosys (Swofford \& Selander, 1989) foi utilizado para obter as estimativas desses índices, utilizando a metodologia proposta por Nei (1987):

$$
\begin{gathered}
\mathrm{F}_{\mathrm{IT}}=1-\frac{\mathrm{H}_{\mathrm{o}}}{\mathrm{H}_{\mathrm{e}}} \\
\text { onde: } \mathrm{H}_{\mathrm{o}}=\text { frequência observada de heterozigotos; } \\
\mathrm{H}_{\mathrm{e}}=\text { frequência esperada de heterozigotos. } \\
\mathrm{F}_{\mathrm{ST}}=\frac{\sigma_{\mathrm{p}}^{2}}{\overline{\mathrm{p}}(1-\overline{\mathrm{p}})} \\
\text { onde: } \bar{p}=\text { frequência média do alelo na população; } \\
1-\bar{p}=\text { frequência média do alelo diferente de p; } \\
\sigma_{p}^{2}=\text { variância das frequências gênicas entre as } \\
\text { subpopulações dada por: }
\end{gathered}
$$




$$
\sigma_{\mathrm{p}}^{2}=\frac{1}{\mathrm{n}}\left[\sum_{1}^{\mathrm{n}} \mathrm{p}_{\mathrm{u}}^{2} \frac{\left(\sum_{\mathrm{l}}^{\mathrm{n}} \mathrm{p}_{\mathrm{u}}\right)^{2}}{\mathrm{n}}\right] \text { onde } n=\text { número de subpopulações. }
$$

A média de $F_{\mathrm{ST}}$ para um loco com $m$ alelos foi dada por:

$$
\overline{\mathrm{F}}_{\mathrm{ST}}=\frac{\sum_{\mathrm{m}} \sigma_{\mathrm{p}_{\mathrm{u}}}^{2}}{\sum_{\mathrm{m}} \overline{\mathrm{p}}_{\mathrm{u}}\left(1-\overline{\mathrm{p}}_{\mathrm{u}}\right)}
$$

Em cada subpopulação, o índice $F_{\mathrm{IS}}$ para cada alelo é dado por:

$$
F_{1 s_{k}}=\frac{P_{u u l k}-p_{u l k}^{2}}{p_{u l k}\left(1-p_{u l k}\right)}
$$

onde: $\mathrm{Puu}_{\mathrm{lk}}=$ frequência de genótipos homozigotos para o alelo $\mathrm{A}_{v}$ do loco 1 na subpopulação k;

$$
\begin{aligned}
\mathrm{p}^{2} \mathrm{u}_{\mathrm{k}}= & \text { frequência esperada dos homozigotos para o alelo } \mathrm{A}_{\mathrm{u}} \text { do } \\
& \text { loco } \mathrm{I} \text { na subpopulação } \mathrm{k} ; \\
\mathrm{pu}_{\mathrm{lk}}= & \text { frequência do alelo } \mathrm{A}_{\mathrm{u}} \text { do loco } 1 \text { na subpopulação } \mathrm{k} ; \\
1-\mathrm{pu}_{\mathrm{lk}}= & \text { frequência do alelo diferente de } \mathrm{A}_{\mathrm{u}} \text { do } \\
& \text { loco } \mathrm{l} \text { na subpopulação } \mathrm{k} .
\end{aligned}
$$

Considerando as subpopulações em conjunto, a média de $\mathrm{F}_{\mathrm{IS}}$ foi dada por:

$$
\overline{\mathrm{F}}_{\mathrm{IS}}=1-\frac{\overline{\mathrm{H}}_{\mathrm{o}}}{\overline{\mathrm{D}}}
$$


sendo:

$$
\overline{\mathrm{H}}_{\mathrm{o}}=\frac{\sum \overline{\mathrm{H}}_{\mathrm{ok}}}{\mathrm{k}} \quad \text { e } \quad \overline{\mathrm{D}}=\frac{\sum \overline{\mathrm{D}}_{\mathrm{k}}}{\mathrm{k}}
$$

onde:

$\overline{\mathrm{H}}_{\mathrm{ak}}=$ média da heterozigosidade para todos os locos da subpopulação $k$;

$\overline{\mathrm{D}}_{\mathrm{k}}=$ média da diversidade gênica para todos os locos da subpopulação $k$;

$\mathrm{k}=$ número de subpopulações.

A significância dos valores médios de $F_{\text {IS }}$ e $F_{\text {IT }}$ por loco foi testada pelo método de $\chi^{2}$ de acordo com Li \& Horwitz (1953):

$$
\chi^{2}=\mathrm{NF}^{2}(\mathrm{k}-1) \quad \text { com GL }=\mathrm{k}[(\mathrm{k}-1) / 2]
$$

onde: $\mathrm{N}=$ tamanho médio das amostras;

$\mathrm{k}=$ número de subpopulações.

A significância do valor de $\mathrm{F}_{\mathrm{ST}}$ foi dada pelo teste de independência das frequências gênicas. Para os locos com dois alelos, $o$ valor de $\chi^{2}$ corresponde ao obtido no ítem 3.2.7.4. Para os locos com mais de dois alelos esse teste corresponde à significância de $\mathrm{F}_{\mathrm{ST}}$ por alelo. $\mathrm{O}$ teste de significância do valor médio de $\mathrm{F}_{\mathrm{ST}}$ nesses locos foi realizado com todas as contagens gênicas simultaneamente (Weir, 1996). Nesse caso, os alelos raros foram agrupados, sempre que a menor classe esperada foi menor do que 1 . Para testar a 
significância da média de $\mathrm{F}_{\mathrm{ST}}$ entre locos, a propriedade de aditividade do $\chi^{2}$ foi utilizada, considerando que os locos são independentes (Vencovsky, 1996 ${ }^{5}$ ).

\subsubsection{Cálculo de $F$ a partir da genealogia}

O coeficiente de endogamia foi calculado a partir das genealogias dos animais, consideradas até o primeiro animal bimestiço, utilizando o método de Quass ( 1976) contido no programa MTDFREML (Boldman et al., 1993).

\subsubsection{Distâncias genéticas}

Com a finalidade de verificar a divergência das gerações de Canchim com relação às raças utilizadas na sua formação as Distâncias Euclidiana Média (Sneath \& Sokal, 1973) e a Distância de Nei corrigida para pequenas amostras (Nei, 1978) foram calculadas. As frequências para os marcadores $\kappa$-caseína , $\beta$-lactoglobulina e hormônio de crescimento nas raças Nelore, Guzerá e Gir foram obtidas da literatura e de dados não publicados do Laboratório de Biotecnologia Animal (ESALQ/USP). Para os marcadores de DNA microssatélite, apenas informações provenientes da raça Nelore eram disponíveis. A distância entre dois grupos $\left(D_{\mathrm{xy}}\right)$ foi dada por:

$$
\mathrm{D}_{\mathrm{xy}}=\sqrt{\frac{1}{\mathrm{p}} \sum \sum_{\mathrm{u}}\left(\mathrm{x}_{\mathrm{lu}}-\mathrm{y}_{\mathrm{lu}}\right)^{2}}
$$

onde: $\mathrm{p}=$ número de alelos;

$x_{l u}$ e $y_{l u}=$ frequência do alelo $A_{u}$ do loco 1 no grupo x e $y$, respectivamente.

\footnotetext{
5 Vencovsky, R. Comunicação pessoal. Departamento de Genética. Escola Superior de Agricultura "Luiz de Queiroz", Universidade de São Paulo. Piracicaba - SP.
} 
A distância genética de Nei (1978) foi calculada pela fómula:

$$
D_{i j}=-n \frac{\left(\frac{\sum_{k} \mid x_{k y} x_{k j}}{\sqrt{\sum x_{k y}^{2} x_{k j}^{2}}}\right)}{\sqrt{\frac{2 n_{i} \sum x_{k i}^{2}-1}{2 n_{i}-1} \frac{2 n_{j} \sum x_{k j}^{2}-1}{2 n_{j}-1}}}
$$

onde: $x^{2}{ }_{k i}$ e $x^{2}{ }_{k j}=$ frequência do alelo $k$ nas populações i e j, respectivamente; $n_{i}$ e $n_{j}=$ tamanho da amostra das populações i e j, respectivamente.

Os valores de distância genética obtidos foram utilizados para a construção de dendrogramas pelo método de agnupamento UPGMA (Unweighted Pair Group using an Arithmetic Average) no qual a distância entre dois grupos é definida pela média das distâncias entre pares de indivíduos pertencentes a grupos diferentes. 


\section{RESULTADOS E DISCUSSÃO}

\subsection{Kappa-caseína}

Para a identificação dos alelos A e B de א-caseína, um segmento de 350 pares de bases desse gene foi amplificado pela técnica de PCR, e digerido com a enzima Hinfl. 0 alelo A foi caracterizado pela presença de três fragmentos de restrição, com 134, 132 e 84 pares de bases, respectivamente. A digestão do alelo B produziu fragmentos de 266 e 84 pares de bases. Os padrões dos três genótipos de $\kappa$-caseína, após eletroforese em gel de agarose, são apresentados na Figura 1.

Os homozigotos para o alelo $\mathbf{A}$ apresentaram duas bandas. A primeira corresponde aos fragmentos de 134 e 132 pares de bases que, nas condições utilizadas, não puderam ser separados no gel. A segunda banda corresponde ao fragmento de 84 pares de bases. Nos homozigotos para o alelo $\mathbf{B}$ duas bandas foram observadas, com tamanhos de 266 e 84 pares de bases. Os heterozigotos foram caracterizados pela presença de três bandas, correspondentes à combinação dos dois padrões descritos anteriormente.

As frequências dos alelos $\mathbf{A}$ e $\mathbf{B}$ nas quatro gerações de Canchim são apresentadas na Tabela 3. A significância da variação de frequência gênica entre classes foi analisada pelo teste de independência para tabelas de contingência. $O$ valor de quiquadrado obtido não foi significativo (Tabela 3), sugerindo que as diferenças observadas entre classes foram aleatórias. 


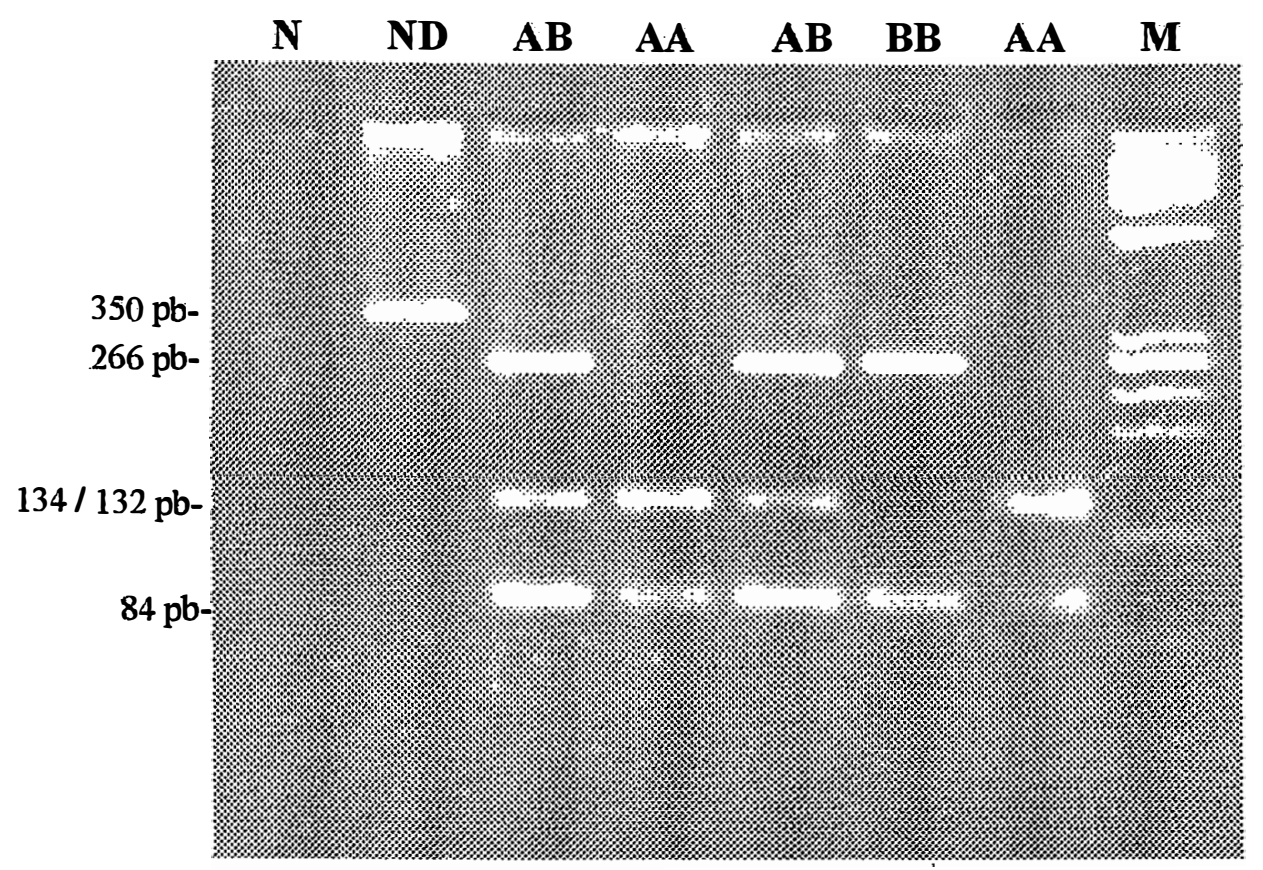

Figura 1. Padrão de fragmentos do produto de amplificação de $\kappa$-caseína digerido com a enzima Hinfl. No alto da figura: N (controle negativo); ND (produto de PCR não digerido); AA, AB e BB (genótipos observados); $\mathbf{M}$ (marcador de tamanho ФX174RF-HaeIII). Os números ao lado da figura indicam o tamanho de cada fragmento. 
Tabela 3. Frequências estimadas e erro-padrão da estimativa para os alelos $\mathrm{A}$ e B de к-caseína em Canchim.

\begin{tabular}{cccccc}
\hline & \multicolumn{5}{c}{ Classes } \\
\cline { 2 - 5 } Alelos & $\mathrm{G}_{3}$ & $\mathrm{G}_{4}$ & $\mathrm{G}_{5}$ & $\mathrm{G}_{6}$ & Total \\
\hline A & $0,500 \pm 0,072$ & $0,719 \pm 0,050$ & $0,677 \pm 0,050$ & $0,671 \pm 0,052$ & $0,659 \pm 0,027$ \\
B & $0,500 \pm 0,072$ & $0,281 \pm 0,050$ & $0,323 \pm 0,050$ & $0,329 \pm 0,052$ & $0,341 \pm 0,027$ \\
\hline$\chi^{2}{ }_{3 \mathrm{GL}}$ & \multicolumn{4}{c}{$6,927^{\text {n.s }}$} & \multicolumn{3}{c}{$\mathrm{P}=0,074$} \\
\hline
\end{tabular}

$\mathrm{P}=$ probabilidade associada ao teste de $\chi^{2}$ de independência.

É importante ressaltar que a classe $G_{3}$ foi representada por todos os animais de geração menor ou igual a 3,5 que haviam sido mantidos no rebanho e que, portanto, não constitui uma amostra aleatória dessas gerações.

$\mathrm{O}$ número de animais de cada genótipo de $\kappa$-caseína nas quatro amostras do rebanho Canchim, bem como o total observado no rebanho, é apresentado na Tabela 4. Nessa Tabela encontram-se também os valores de $\chi^{2}$ para o teste de aderência às proporções de equilibrio de Hardy-Weinberg. Em todas as amostras, os desvios com relação às proporções esperadas não foram significativos. Esse resultados indicam que os acasalamentos ocorrem ao acaso com relação aos genótipos nesse loco, tanto nas classes individuais, quanto na população como um todo. A condição de equilibrio para um loco marcador é frequentemente observada nas espécies domésticas, demonstrando que mesmo quando a população sofre a intervenção do homen, quebrando uma ou mais condições pressupostas pela teoria de Hardy-Weinberg, existe um equilíbrio entre os efeitos de seleção, mutação e deriva com relação aos polimorfismos neutros.

Esses resultados vão de encontro aos obtidos na raça Hereford, na qual observou-se uma grande influência do polimorfismo de $\kappa$-caseína sobre características de desempenho. Naquela raça, os efeitos da substituição do alelo A pelo alelo $\mathbf{B}$ sobre a DEP para peso ao nascimento, peso à desmama e produção de leite da mãe foram negativos, sugerindo que o alelo A seria favorável para essas características (Moody et $a l, 1994)$. Estudos em raças leiteiras têm demonstrado a associação entre o alelo $\mathbf{B}$ da $\kappa-$ 
caseína e maior concentração de proteína no leite ( Ng-Kwai-Hang et al., 1984). Os resultados obtidos no presente trabalho não sugerem a existência de efeito da seleção praticada no rebanho sobre o polimorfismo de $\kappa$-caseína. Considerando que as características de produção e qualidade do leite representam apenas uma parte das variáveis envolvidas no efeito materno, e que este é apenas um entre os muitos fatores que afetam o crescimento, o efeito da seleção indireta não deveria resultar em mudanças bruscas da frequência gênica. Apesar de existir uma tendência linear de aumento da frequência do alelo $B$ entre as classes $G_{4}$ a $G_{6}$, a magnitude dessas mudanças de frequência não foi significativa, não sendo possível, portanto, descartar a hipótese de efeito de amostragem.

Tabela 4. Distribuição dos genótipos de $\kappa$-caseína nas quatro gerações de Canchim e valores de $\chi^{2}$ para o teste de aderência às proporções de Hardy-Weinberg.

\begin{tabular}{cccccc}
\hline & \multicolumn{5}{c}{ Classes } \\
\cline { 2 - 5 } Genótipo & $\mathrm{G}_{3}$ & $\mathrm{G}_{4}$ & $\mathrm{G}_{5}$ & $\mathrm{G}_{6}$ & Total \\
\hline $\mathrm{AA}$ & $5(6)$ & $20(21,23)$ & $22(22,00)$ & $18(18,46)$ & $65(66,88)$ \\
$\mathrm{AB}$ & $14(12)$ & $19(16,55)$ & $21(20,99)$ & $19(18,10)$ & $73(69,21)$ \\
$\mathrm{BB}$ & $5(6)$ & $2(3,22)$ & $5(5,01)$ & $4(4,44)$ & $16(17,91)$ \\
\hline $\mathrm{N}$ & 24 & 41 & 48 & 41 & 154 \\
\hline$\chi^{2}$ & 0,667 & 0,898 & 0 & 0,100 & 0,464
\end{tabular}

( ) Valores esperados de acordo com a hipótese de equilíbrio de Hardy-Weinberg.

Para $\alpha=0,05$ e GL $=1, \chi_{\text {critico }}^{2}=3,84$

$\mathrm{Na}$ amostra da raça Charolesa, os alelos $\mathbf{A}$ e $\mathbf{B}$ de $\kappa$-caseína apresentaram frequências de 0,514 e 0,486, respectivamente (Tabela 5). A frequência do alelo $\mathrm{A}$ nessa raça foi inferior à observada na raça Simmental $(0,73)$ que, de acordo com a literatura, tem origem semelhante à da raça Charolesa (Schellander et al., 1992). As frequências 
genotípicas de $\kappa$-caseína na raça Charolesa também estão de acordo com o esperado sob equilíbrio de Hardy-Weinberg (Tabela 5).

Tabela 5. Distribuição dos genótipos e frequências gênicas de $\kappa$-caseína em animais da raça Charolesa.

\begin{tabular}{ccc}
\hline Genótipos & Observado (Esperado) & Frequências gênicas \\
\hline AA & $9(9,5)$ & $\mathrm{A}=0,514 \pm 0,059$ \\
AB & $19(18,0)$ & \\
BB & $8(8,5)$ & $\mathrm{B}=0,486 \pm 0,059$ \\
\hline N & 36 & \\
\hline$\chi^{2}$ & $0,11^{\text {n.s. }}$ & \\
\hline
\end{tabular}

( ) Valores esperados sob a hipótese de equilíbrio de Hardy-Weinberg.

Para $\alpha=0,05$ e $G L=1, \chi_{\text {critico }}^{2}=3,84$.

\subsection{Betalactoglobulina}

Um segmento de 262 pares de bases do gene da $\beta$-lactoglobulina, que contém um polimorfismo de restrição para a enzima HaeIII, foi amplificado. A digestão do DNA amplificado a partir do alelo A produziu fragmentos de 153 e 109 pares de bases. $\mathbf{O}$ alelo B caracteriza-se pela presença de um segundo sítio de restrição dentro do fragmento de 153 pares de bases, resultando em três fragmentos com 79, 74 e 109 pares de bases, respectivamente.

O padrão de bandas obtido para os três genótipos de $\beta$-lactoglobulina é apresentado na Figura 2. 


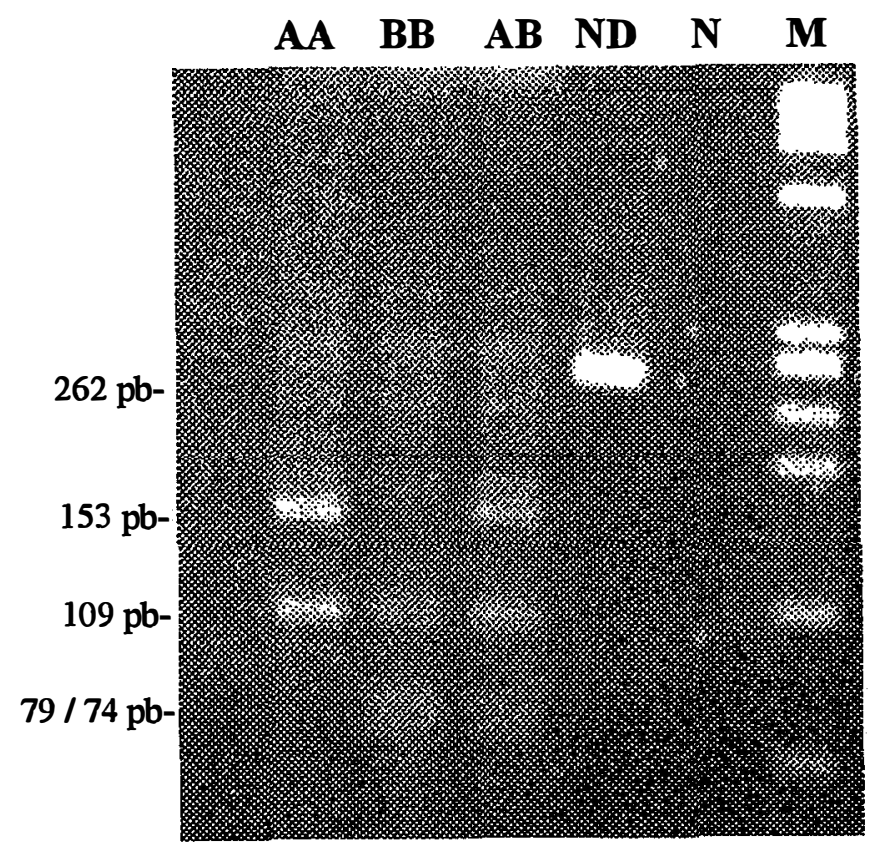

Figura 2. Padrão de fragmentos de restrição obtido com a enzima HaeIII nos diferentes genótipos de $\beta$-lactoglobulina. No alto da figura: $\mathbf{A A}, \mathbf{B B}, \mathbf{A B}=$ genótipos; ND = produto de PCR não digerido; $\mathbf{N}=$ controle negativo; $\mathbf{M}=$ marcador de tamanho $\varnothing \mathrm{X} 174 \mathrm{RF}-H a e \Pi$ I. Os números ao lado da figura indicam o tamanho de cada fragmento em pares de bases. 
As frequências gênicas para esse marcador são apresentadas na Tabela 6 . $O$ teste de independência entre as frequências gênicas e as gerações foi não significativo. Dessa forma, admite-se que a variação das frequências entre classes foi aleatória. Esses resultados sugerem que esse polimorfismo não está associado às características fenotípicas sujeitas à seleção nesse rebanho.

Tabela 6. Frequências estimadas e erro-padrão da estimativa para os alelos A e B de $\beta$ lactoglobulina em Canchim.

\begin{tabular}{|c|c|c|c|c|c|}
\hline \multirow[b]{2}{*}{ Alelos } & \multicolumn{4}{|c|}{ Classes } & \multirow[b]{2}{*}{ Total } \\
\hline & $\mathrm{G}_{3}$ & $\mathrm{G}_{4}$ & $\mathrm{G}_{5}$ & $\mathrm{G}_{6}$ & \\
\hline A & $0,417 \pm 0,071$ & $0,463 \pm 0,055$ & $0,479 \pm 0,051$ & $0,402 \pm 0,054$ & $0,445 \pm 0,028$ \\
\hline B & $0,583 \pm 0,071$ & $0,537 \pm 0,055$ & $0,521 \pm 0,051$ & $0,598 \pm 0,054$ & $0,555 \pm 0,028$ \\
\hline$\chi^{2} 3 \mathrm{GL}$ & $1,324^{\text {n.s. }}$ & & $P=0,732$ & & \\
\hline
\end{tabular}

$\mathrm{P}=$ probabilidade associada ao teste de $\chi^{2}$ de independência.

A distribuição dos três genótipos de $\beta$-lactoglobulina em cada geração do rebanho Canchim é apresentada na Tabela 7. Os desvios em relação às proporções esperadas sob a hipótese de equilibrio não foram significativos.

$\mathrm{Na}$ raça Charolesa, a frequência do alelo $\mathbf{A}$ foi de 0,542 ( Tabela 8), superior à frequência observada em outras raças européias. O número de animais observados em cada classe genotípica na amostra da raça Charolesa está de acordo com o esperado sob equilíbrio de Hardy-Weinberg (Tabela 8), reforçando a hipótese de que esse polimorfismo 
não desempenha um papel importante em animais selecionados para produção de came. As frequências do alelo A de $\beta$-lactoglobulina nas raças Holandesa, Suíça Parda, Guernsey, Shorthorn Leiteiro e Jersey, estimadas por Van Eenennaam \& Medrano (1991), foram de $0,43,0,39,0,21,0,31$ e 0,37 , respectivamente. Em rebanhos brasileiros da raça Nelore a frequência desse alelo foi de 0,33 e de 0,37 na raça Gir (Kemenes, 1996). A distribuição desse polimorfismo nas raças européias especializadas para produção de carne é pouco documentada. Na raça Hereford a frequência do alelo A foi de 0,72 (Moody et al., 1994).

Tabela 7. Distribuição dos genótipos de $\beta$-lactoglobulina nas quatro gerações de Canchim e valores de $\chi^{2}$ para o teste de aderência às proporções de HardyWeinberg.

\begin{tabular}{cccccc}
\hline & \multicolumn{5}{c}{ Classes } \\
Genótipo & $\mathrm{G}_{3}$ & $\mathrm{G}_{4}$ & $\mathrm{G}_{5}$ & $\mathrm{G}_{6}$ & Total \\
\hline $\mathrm{AA}$ & $6(4,17)$ & $7(8,79)$ & $8(11,01)$ & $7(6,63)$ & $28(30,50)$ \\
$\mathrm{AB}$ & $8(11,67)$ & $24(20,39)$ & $30(23,96)$ & $19(19,71)$ & $81(76,07)$ \\
$\mathrm{BB}$ & $10(8,16)$ & $10(11,82)$ & $10(13,03)$ & $15(14,66)$ & $45(47,43)$ \\
\hline $\mathrm{N}$ & 24 & 41 & 48 & 41 & 154 \\
\hline$\chi^{2}$ & $2,372^{\text {ns. }}$ & $1,284^{\text {ns. }}$ & $3,050^{\text {ns. }}$ & $0,054^{\text {ns. }}$ & $0,649^{\text {ns }}$ \\
\hline
\end{tabular}

( )Valores esperados de acordo com as proporções de equilíbrio de Hardy-Weinberg. Para $\alpha=0,05$ e G.L. $=1, \chi_{\text {critico }}^{2}=3,84$ 
Tabela 8. Distribuição dos genótipos de $\beta$-lactoglobulina, frequências gênicas e valores de $\quad \chi^{2}$ para o teste de aderência ao equilíbrio de Hardy-Weinberg na raça Charolesa.

\begin{tabular}{ccc}
\hline Genótipo & Observado & Frequências gênicas \\
\hline AA & $9(10,56)$ & $\mathrm{A}=0,542 \pm 0,059$ \\
AB & $21(17,88)$ & \\
BB & $6(7,56)$ & $\mathrm{B}=0,458 \pm 0,059$ \\
\hline $\mathrm{N}$ & 36 & \\
\hline$\chi^{2}$ & $1,078^{\text {ns }}$ & \\
\hline
\end{tabular}

ns = não significativo.

() Valores esperados de acordo com as proporções de equilíbrio de Hardy-Weinberg.

\subsection{Polimorfismo do gene do hormônio de crescimento}

As duas variantes genéticas descritas para o hormônio de crescimento diferem pela presença de uma leucina ou de uma valina na posição 127 desse polipeptídeo. Essa substituição de aminoácidos é decorrente de uma substituição de nucleotídeos no DNA e resulta na introdução de um sítio de restrição para a enzima $A$ luI no alelo que codifica o aminoácido valina.

Com a finalidade de identificar os alelos L (leucina) e V (valina) desse gene, uma sequência de 223 pares de bases, que contém essa mutação, foi amplificada. A digestão dos produtos de PCR com a enzima AluI produziu fragmentos de 171 e 52 pares de bases nos animais homozigotos para o alelo L (Figura 3). Os homozigotos para o alelo $\mathrm{V}$ foram caracterizados pela ausência de digestão dos produtos de PCR e os heterozigotos apresentaram os três fragmentos (223, 171 e 52 pares de bases). 
M LL LL LL LL LL LL LL ND LL LL LL VV VV LL LL LV N

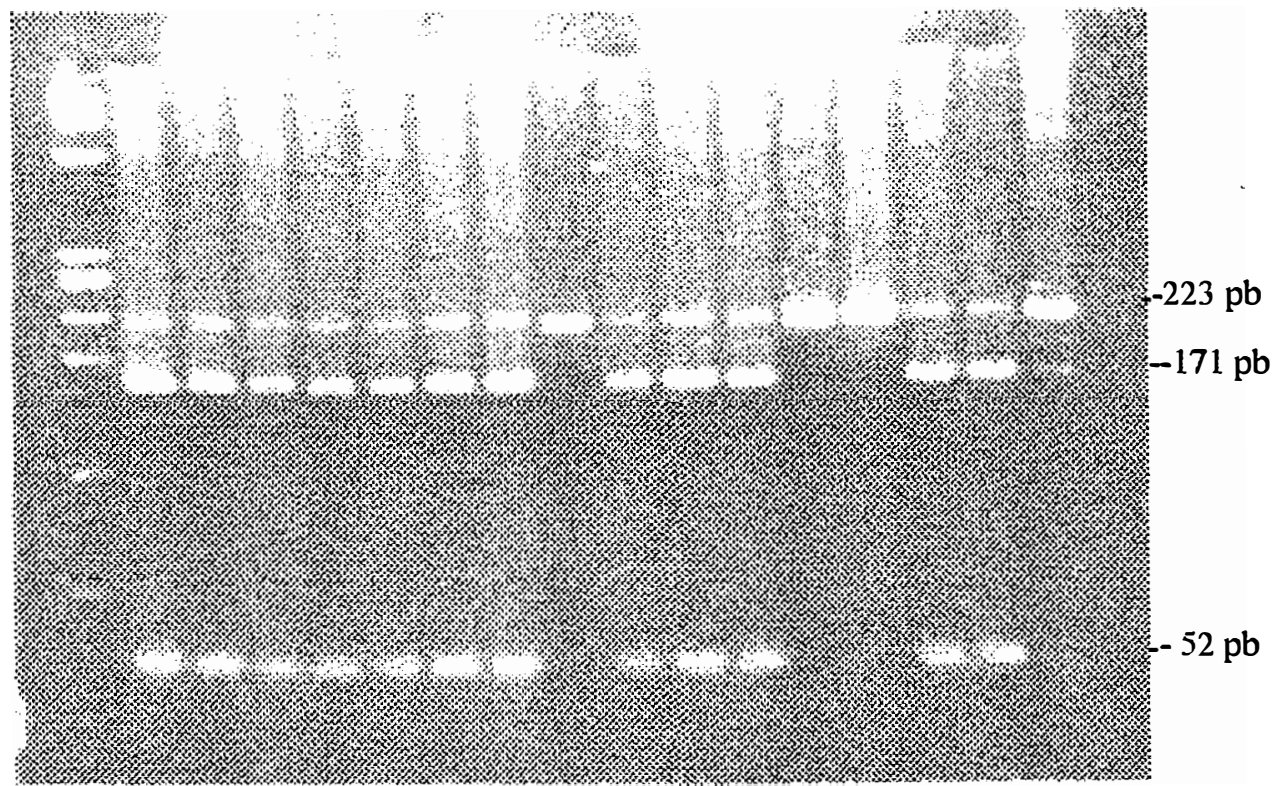

Figura 3. Padrão de restrição obtido com a enzima $A l u$ I nos diferentes genótipos de

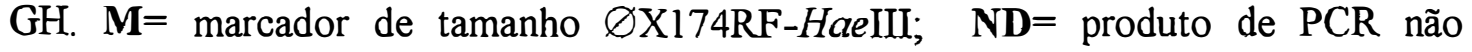
digerido; LL, $\mathbf{V V}, \mathbf{L V}=$ genótipos observados; $\mathbf{N}=$ controle negativo de amplificação. $\mathrm{O}$ tamanho de cada fragmento é indicado ao lado da figura. 
As frequências estimadas para os alelos $\mathbf{L}$ e $\mathbf{V}$ do gene do hormônio de crescimento variaram significativamente entre as amostras de gerações do rebanho Canchim (Tabela 9). $O$ valor de $\chi^{2}$ para o teste de independência entre as frequências gênicas estimadas e as quatro classes foi significativo a $5 \%$ tendo se aproximado da significância a $1 \%(P=0,01)$, indicando a existência de uma relação entre frequência gênica e gerações.

Tabela 9. Frequências dos alelos $\mathrm{L}$ e $\mathrm{V}$ de hormônio de crescimento e respectivos erros padrões nas quatro gerações de Canchim.

\begin{tabular}{cccccc}
\hline & \multicolumn{5}{c}{ Classes } \\
\cline { 2 - 5 } Alelos & $\mathrm{G}_{3}$ & $\mathrm{G}_{4}$ & $\mathrm{G}_{5}$ & $\mathrm{G}_{6}$ & Total \\
\hline $\mathrm{L}$ & $0,958 \pm 0,030$ & $0,890 \pm 0,034$ & $0,927 \pm 0,026$ & $0,793 \pm 0,045$ & $0,886 \pm 0,018$ \\
$\mathrm{~V}$ & $0,042 \pm 0,030$ & $0,110 \pm 0,034$ & $0,073 \pm 0,026$ & $0,207 \pm 0,045$ & $0,114 \pm 0,018$ \\
\hline$\chi^{2}{ }_{\text {3 GL }}$ & $11,21^{*}$ & $\mathrm{P}=0,01$ & & \\
\hline $\mathrm{P}=$ probabilidade associada ao valor de $\chi^{2}$ &
\end{tabular}

Para identificar se a variação entre as quatro classes apresentava um padrão linear, o qui-quadrado de independência foi decomposto em um componente de regressão e um componente de desvios da regressão (Tabela 10 ). O valor de $\chi^{2}$ obtido para a regressão aproximou-se da significância a $1 \%$. Os desvios com relação à distribuição linear das frequências gênicas foram não significativos permitindo, portanto, a aceitação da hipótese de linearidade. A tendência de aumento da frequência do alelo $\mathbf{V}$ da primeira para a última classe estudada foi confirmada por um coeficiente de regressão positivo de 0,046 (Figura 4). 
Tabela 10. Análise de regressão entre as frequências do alelo $\mathrm{L}$ de $\mathrm{GH}$ e as gerações de Canchim.

\begin{tabular}{llll}
\hline & GL & $\chi^{2}$ & P \\
\hline Regressão & 1 & $6,74^{*}$ & 0,01 \\
$\quad$ Desvios da regressão & 2 & $4,47^{\text {ns }}$ & 0,11 \\
\hline Total & 3 & $11,21^{*}$ & 0,01
\end{tabular}

$\mathrm{P}=$ probabilidade associada aos valores de $\chi^{2}$.

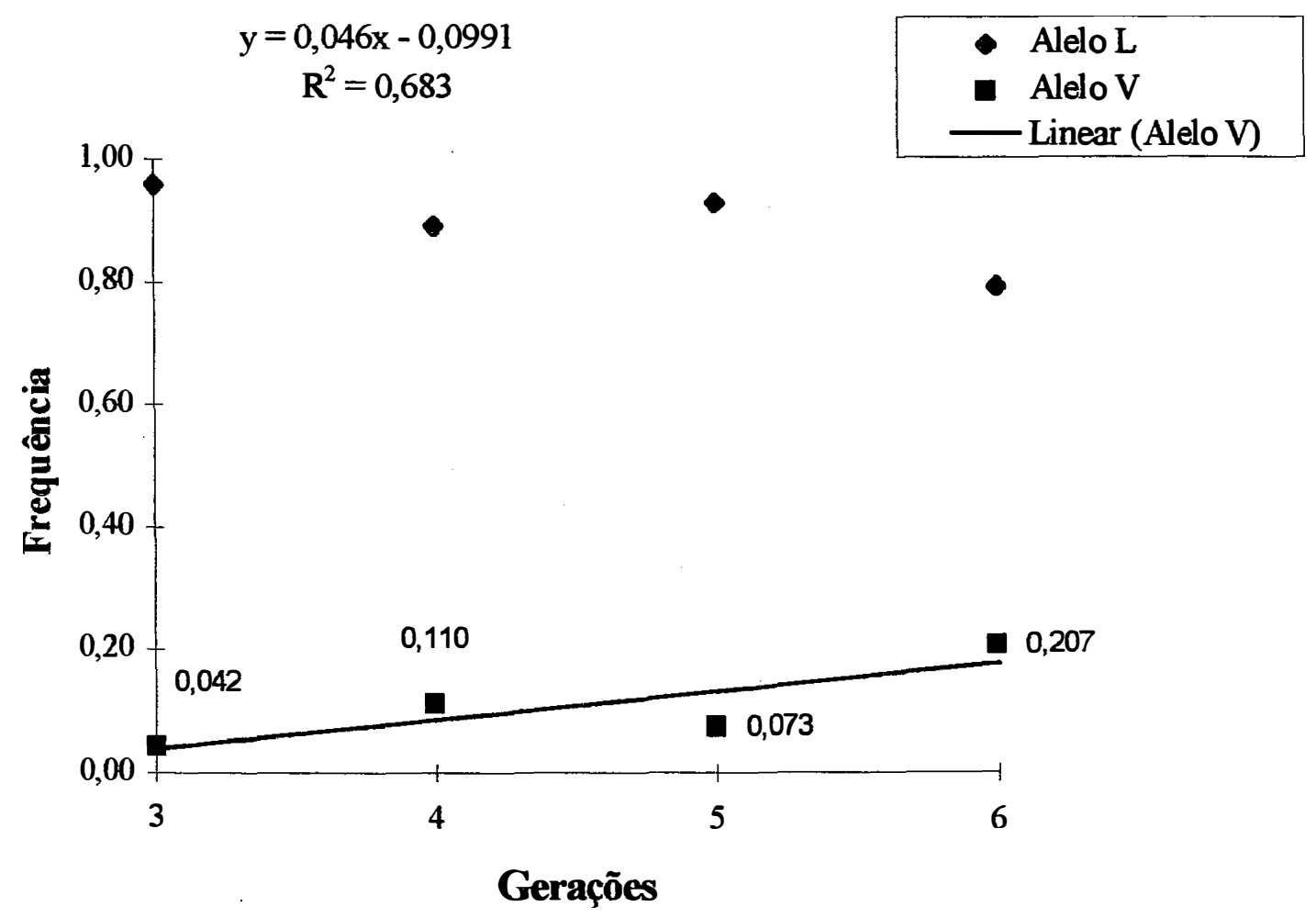

Figura 4. Distribuição das frequências dos alelos de hormônio de crescimento ao longo das gerações de Canchim. 
A distribuição dos genótipos de GH nas quatro amostras de Canchim encontrase na Tabela 11 .

Em função da baixa frequência do alelo $\mathbf{V}$, os valores de qui-quadrado para $\mathbf{o}$ teste de aderência às proporções de equilíbrio foram corrigidos para continuidade, aplicando-se a correção de Yates. Além disso, a probabilidade exata de se obter aleatoriamente uma amostra como a observada foi calculada, utilizando o programa Biosys (Swofford \& Selander, 1989). O teste de equilíbrio por probabilidade exata foi empregado uma vez que, mesmo nas amostras de maior tamanho, as frequências esperadas para os homozigotos VV foram próximas de zero, e, nessas condições, o teste de qui-quadrado não é recomendado. Valores significativos foram obtidos em todos os testes para as classes $\mathrm{G}_{4}$ a $\mathrm{G}_{6}$ e no rebanho considerado como um todo.

Tabela 11. Distribuição dos genótipos de GH nas quatro gerações de Canchim e valores de $\chi^{2}$ para o teste de aderência às proporções de Hardy-Weinberg.

\begin{tabular}{|c|c|c|c|c|c|}
\hline \multirow[b]{2}{*}{ Genótipos } & \multicolumn{4}{|c|}{ Classes } & \multirow[b]{2}{*}{ Total } \\
\hline & $\mathrm{G}_{3}$ & $\mathrm{G}_{4}$ & $\mathbf{G}_{5}$ & $\mathrm{G}_{6}$ & \\
\hline LL & $22(22,04)$ & $35(32,5)$ & $44(41,2)$ & $30(25,8)$ & $131(120,99)$ \\
\hline LV & $2(1,92)$ & $3(8,0)$ & $1(6,5)$ & $5(13,5)$ & $11(31,02)$ \\
\hline VV & $0(0,04)$ & $3(0,5)$ & $3(0,3)$ & $6(1,8)$ & $12(1,99)$ \\
\hline $\mathrm{N}$ & 24 & 41 & 48 & 41 & 154 \\
\hline$\chi^{2}, 1 \mathrm{GL}^{(\mathrm{a})}$ & 0,000 & $10,813^{* *}$ & $34,347^{* *}$ & $16,219^{* *}$ & $58,525^{* *}$ \\
\hline$P^{(b)}$ & 1,000 & 0,002 & 0,000 & 0,000 & 0,000 \\
\hline
\end{tabular}

( )Valores esperados de acordo com as proporções de equilíbrio de Hardy-Weinberg.

${ }^{\text {a }}$ Valores obtidos após correção de Yates. ${ }^{* *}$ Significativo ao nível de 1\%.

${ }^{b}$ Probabilidade calculada pelo teste exato para equilíbrio de Hardy-Weinberg. 
O desequilíbrio observado foi resultante de um excesso de homozigotos em relação ao esperado para essas frequências gênicas, traduzido por valores positivos de coeficiente de fixação de Wright (Tabela 12). Valores positivos de $\mathrm{F}$ são frequentemente interpretados como resultantes de endogamia. Entretanto, a prevenção de acasalamentos entre indivíduos aparentados é praticada no programa de melhoramento desse rebanho Canchim e as estimativas de endogamia com base na genealogia dos animais, que será discutida em mais detalhes na seção 4.9 , foram inferiores a $2 \%$. Na ausência de endogamia, valores de $\mathrm{F}$ positivos podem ser decorrentes de acasalamento preferencial para esse marcador.

Tabela 12. Coeficientes de fixação de Wright (F) para o marcador GH nas amostras do rebanho Canchim.

\begin{tabular}{cccc}
\hline Classe & Ho & He & F \\
\hline $\mathbf{G}_{3}$ & 2 & 1,917 & $-0,043$ \\
$\mathrm{G}_{4}$ & 3 & 8,012 & 0,626 \\
$\mathrm{G}_{5}$ & 1 & 6,490 & 0,846 \\
$\mathrm{G}_{6}$ & 5 & 13,476 & 0,629 \\
\hline Total & 11 & 31,023 & 0,645 \\
\hline
\end{tabular}

$\mathrm{Ho}=$ Heterozigotos observados; $\mathrm{He}=$ Heterozigotos esperados sob equilíbrio. $\mathrm{F}=1-\mathrm{Ho} / \mathrm{He}$.

O hormônio de crescimento desempenha papel fundamental no desenvolvimento dos tecidos, atuando sobre a partição dos nutrientes e sobre a proliferação celular. Dessa forma, o gene GH é considerado um candidato para associação com características de produção em gado de corte. Estudos conduzidos por Schlee et al. (1994a) demonstraram que a mutação que resulta na substituição de leucina por valina influencia as concentrações plasmáticas de hormônio de crescimento e de IGF-I. Nesses estudos os animais de genótipo LL apresentaram maior concentração de GH do que os de genótipo LV. Entretanto, o genótipo LV foi associado a maior concentração de IGF-I. Em virtude 
da baixa frequência do alelo $\mathbf{V}$, nenhuma comparação foi realizada com relação aos homozigotos para esse alelo. Em um estudo posterior, o genótipo de GH influenciou significativamente o desempenho de touros da raça Simmental, tendo sido o genótipo $\mathbf{L V}$ associado a um maior valor para ganho de carcaça e para valor da came. O genótipo VV foi superior para classificação de carcaça (Schlee et al., 1994b).

Os resultados obtidos no presente trabalho, sugerem que, no rebanho da raça Canchim, um ou mais fatores devem estar atuando no sentido de aumentar a frequência do alelo V. A hipótese de seleção é reforçada pelos valores do coeficiente de fixação obtidos para esse loco (Tabela 12) que foram positivos e altos em todas as gerações, com exceção da geração 3 .

As frequências dos alelos $\mathbf{L}$ e $\mathrm{V}$ na amostra da raça Charolesa foram de 0,736 e 0,264 , respectivamente (Tabela 13). Nessa amostra, os desvios das proporções genotípicas observadas não foram significativos, sugerindo que a população se encontra em equilíbrio.

Tabela 13 . Distribuição dos genótipos e frequências gênicas para o loco GH em animais da raça Charolesa.

\begin{tabular}{ccc}
\hline Genótipos & No $(\mathrm{Ne})$ & Frequências gênicas \\
\hline LL & $19(19,5)$ & \\
LV & $15(14,0)$ & $\mathrm{L}=0,736 \pm 0,052$ \\
$\mathrm{VV}$ & $2(2,5)$ & $\mathrm{V}=0,264 \pm 0,052$ \\
\hline $\mathrm{N}$ & 36 & \\
\hline$\chi^{2}, 1 \mathrm{GL}^{\text {(a) }}$ & $0,190^{\text {ns }}$ &
\end{tabular}

( )Valores esperados de acordo com as proporções de equilíbrio de Hardy-Weinberg.

${ }^{a}$ Valores obtidos após correção de Yates. Para $\alpha=0,05$ e G.L. $=1, \chi_{\text {critico }}^{2}=3,84$

A única referência encontrada na literatura sobre a ocorrência desse polimorfismo em raças zebuínas foi o trabalho de Mitra et al. (1995), que observou uma frequência de 0,04 para o alelo $\mathbf{V}$ em uma amostra de 57 animais da raça Sahiwal na 
Índia. A fixação do alelo $\mathbf{L}$ em populações zebuínas mantidas em outros países foi observada por DeNise (19967) em uma amostra da raça Brahman, e por Rosa et al. (1996) em 63 animais da raça Nelore. Resultados semelhantes foram obtidos em amostras das raças Gir e Guzerá (Coutinho, $1996^{8}$ ). Na ausência de dados sobre a frequência desse alelo em outras raças indianas, a interpretação do monomorfismo observado nesses rebanhos de zebuínos se torna complexa. Considerando que a frequência em outras raças fosse semelhante à observada na raça Sahival, a perda de polimorfismo poderia ser resultante da amostragem durante a importação dos animais para esses países.

Com base no exposto é provável que o alelo $\mathrm{V}$ que, de acordo com os resultados apresentados estaria sendo favorecido pela seleção no rebanho Canchim, seja proveniente da raça Charolesa.

\subsection{Microssatélite do gene IGF-I ( MS-IGF-I)}

A região flanqueadora 5' do gene do Fator de Crescimento Semelhante à Insulina do Tipo I (IGF-I) apresenta uma repetição do dinucleotídeo CA. Para identificar a variação resultante do número de repetições nessa região, o DNA dos animais foi amplificado com os "iniciadores" descritos por Bishop et al. (1994).

A separação dos produtos de PCR em géis de poliacrilamida desnaturante, seguida de autorradiografia, permitiu a identificação de quatro alelos na raça Canchim, com tamanhos de 231, 229, 227 e 225 pares de bases ( Figura 5). Esses tamanhos estão de acordo com os observados por Bishop et al. (1994) e correspondem, portanto, aos quatro alelos já descritos para esse loco. Para facilitar a análise dos dados, os alelos foram numerados em ordem decrescente de tamanho.

As frequências dos alelos do MS-IGF-I nas amostras do rebanho Canchim se encontram na Tabela 14. O comportamento dessas frequências ao longo das gerações é ilustrado na Figura 6.

\footnotetext{
${ }^{7}$ DeNise, S. University of Arizona. Comunicação pessoal, 1996.

${ }^{8}$ Coutinho, L.L. Departamento de Zootecnia. Escola Superior de Agricultura "Luiz de Queiroz"- USP. Piracicaba, SP. Comunicação pessoal, 1996.
} 

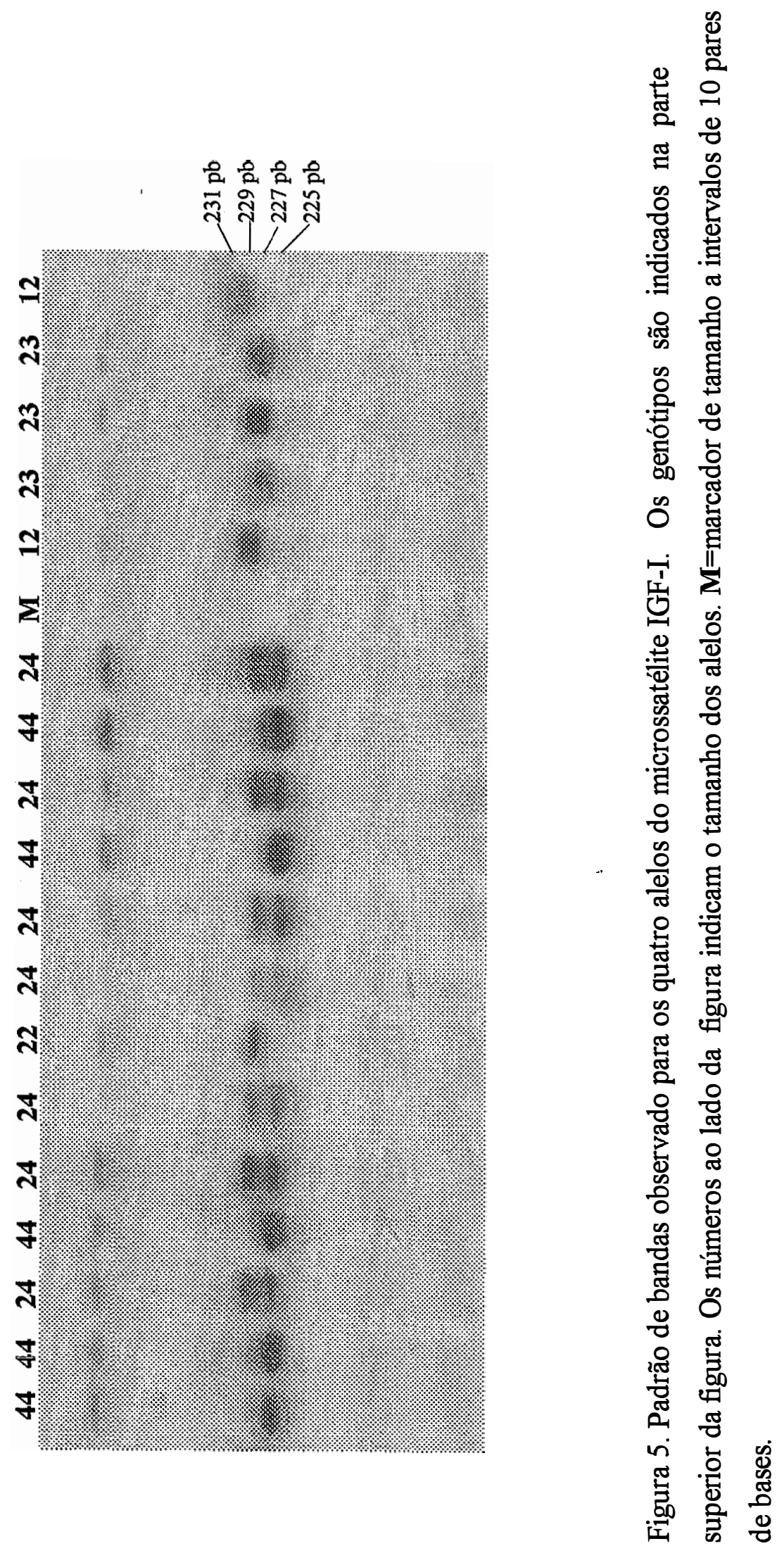
Tabela 14. Frequências dos alelos do MS-IGF-I, erros-padrões das estimativas e valores de qui-quadrado para o teste de independência nas diferentes gerações de Canchim.

\begin{tabular}{|c|c|c|c|c|c|c|}
\hline \multirow[b]{2}{*}{ Alelos $^{\mathrm{a}}$} & \multicolumn{4}{|c|}{ Classes } & \multirow[b]{2}{*}{ Total } & \multirow[b]{2}{*}{$\chi_{3 \mathrm{GL}}^{2}$} \\
\hline & $\mathrm{G}_{3}$ & $\mathrm{G}_{4}$ & $\mathrm{G}_{5}$ & $\overline{G_{6}}$ & & \\
\hline $1(231)$ & 0,042 & 0,049 & 0,083 & 0,073 & 0,065 & $1,41^{\mathrm{ns}}$ \\
\hline $2(229)$ & 0,458 & 0,317 & 0,344 & 0,280 & 0,338 & $4,49^{\mathrm{ns}}$ \\
\hline $3(227)$ & 0,375 & 0,585 & 0,479 & 0,439 & 0,481 & $6,32^{\text {ns }}$ \\
\hline $4(225)$ & 0,125 & 0,049 & 0,094 & 0,207 & 0,117 & $9,16^{*}$ \\
\hline $\mathrm{EP} 1^{\mathrm{b}}$ & 0,029 & 0,024 & 0,028 & 0,029 & 0,014 & \\
\hline $\mathrm{EP} 2^{\mathrm{b}}$ & 0,072 & 0,051 & 0,048 & 0,050 & 0,027 & \\
\hline EP $3^{b}$ & 0,070 & 0,054 & 0,051 & 0,055 & 0,028 & \\
\hline $\mathrm{EP} 4^{\mathrm{b}}$ & 0,048 & 0,024 & 0,030 & 0,045 & 0,018 & \\
\hline
\end{tabular}

ns = não significativo; *significativo a $5 \%$.

${ }^{\text {a }} \mathrm{O}$ tamanho de cada alelo em pares de bases é indicado entre parêntesis.

b Erro - padrão associado à estimativa de frequência dos alelos 1, 2, 3 e 4, respectivamente.

$\mathrm{O}$ teste de independência entre as frequências gênicas e as amostras de gerações foi utilizado para cada alelo contra os demais. Observa-se que apenas a frequência do alelo 4 ( $225 \mathrm{pb}$ ) variou significativamente entre as gerações (Tabela 14). 


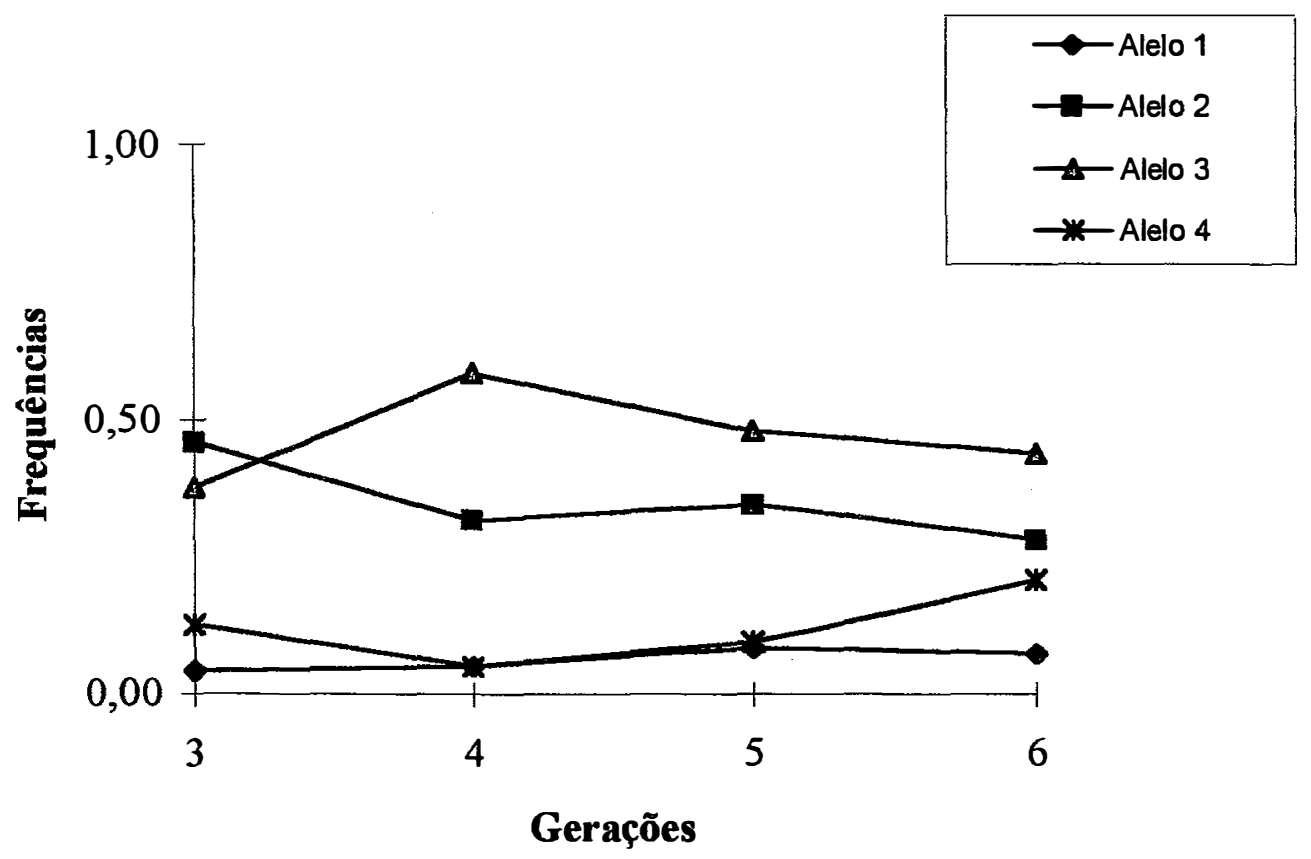

Figura 6. Distribuição das frequências dos alelos do microssatélite IGF-I ao longo das gerações de Canchim.

$\mathrm{O}$ valor de $\chi^{2}$ obtido para o teste de independência entre a frequência desse alelo e as amostras do rebanho foi então decomposto nos componentes de regressão e componente de desvios da regressão linear (Tabela 15). Os resultados dessa análise sugerem que o aumento da frequência do alelo 4 não foi linear ao longo das amostras de gerações, como pode ser observado na Figura 7. 
Tabela 15. Análise de regressão entre as frequências do alelo 4 de IGF-I e as gerações de Canchim.

\begin{tabular}{lccc}
\hline & GL & $\chi^{2}$ & $P$ \\
\hline Regressão & 1 & $0,06^{\text {ns }}$ & 0,81 \\
Desvios da regressão & 2 & $10,18^{*}$ & 0,01 \\
\hline Total & 3 & $10,24^{*}$ & 0,02 \\
\hline
\end{tabular}

$\mathbf{P}=$ probabilidade associada aos valores de $\chi^{2}$.

* Significativo a $5 \%$; ns = não significativo.

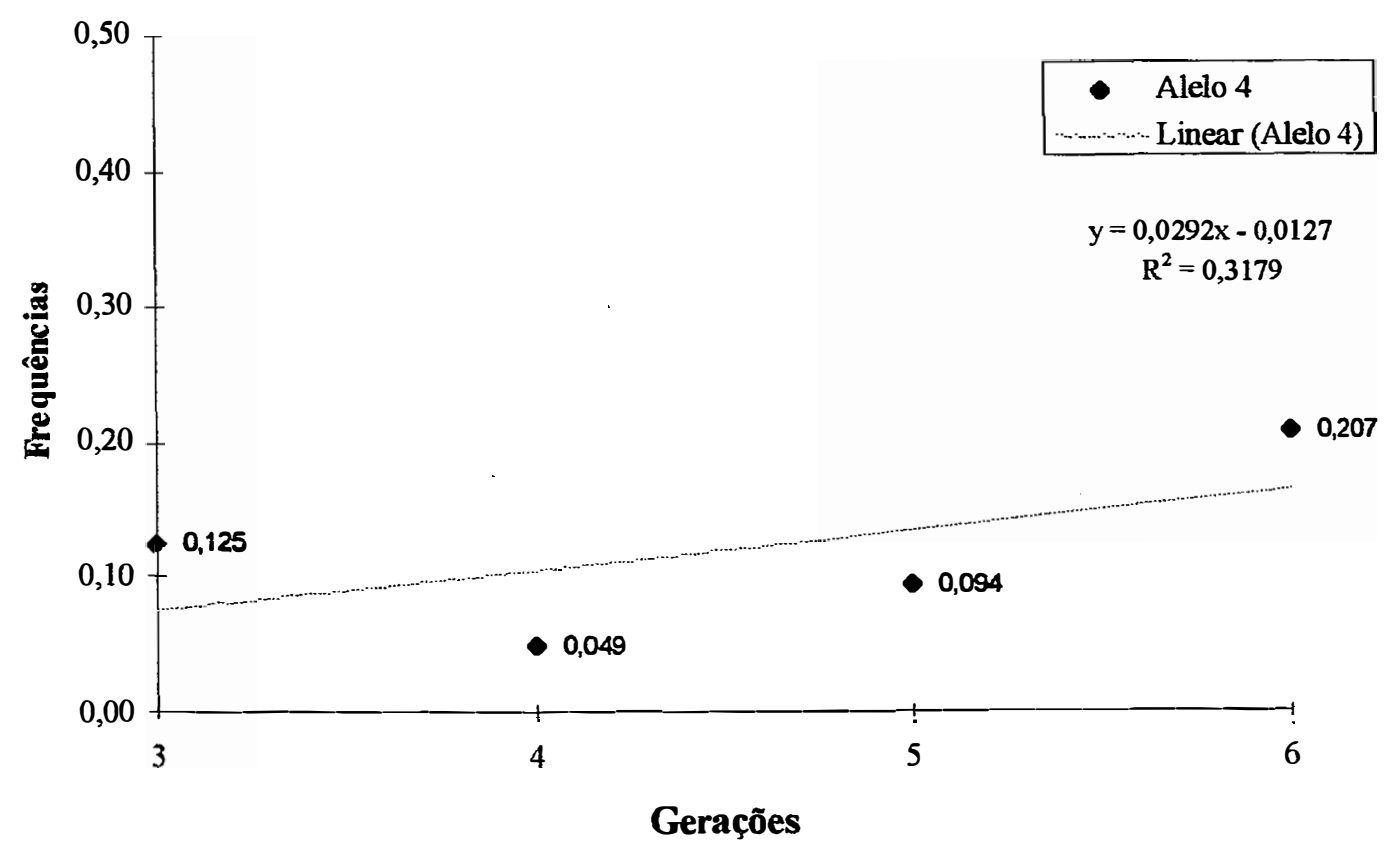

Figura 7. Distribuição das frequências do alelo 4 do microssatélite IGF-I ao longo das gerações de Canchim. 
A distribuição dos diferentes genótipos nas amostras do rebanho Canchim é apresentada na Tabela 16. Em função do número reduzido de animais nas diversas classes genotípicas, para o teste de equilíbrio de Hardy-Weinberg as classes foram agrupadas em três: uma classe representada pelos homozigotos para o alelo mais frequente, uma classe representada pelos heterozigotos para o alelo mais frequente e a classe representada pelos homozigotos e heterozigotos para os alelos raros. Os resultados são apresentados na Tabela 17.

Tabela 16. Distribuição dos genótipos de IGF-I nas quatro amostras do rebanho Canchim.

\begin{tabular}{cccccc}
\hline & \multicolumn{5}{c}{ Classes } \\
\cline { 2 - 5 } Genótipos & $\mathrm{G}_{3}$ & $\mathrm{G}_{4}$ & $\mathrm{G}_{5}$ & $\mathrm{G}_{6}$ & Total \\
\hline $1-1$ & $0(0,04)$ & $0(0,10)$ & $1(0,33)$ & $0(0,22)$ & $1(0,65)$ \\
$1-2$ & $1(0,92)$ & $2(1,27)$ & $3(2,75)$ & $2(1,68)$ & $8(6,75)$ \\
$1-3$ & $1(0,75)$ & $2(2,34)$ & $2(3,83)$ & $3(2,63)$ & $8(9,61)$ \\
$1-4$ & $0(0,25)$ & $0(0,19)$ & $1(0,75)$ & $1(1,24)$ & $2(2,34)$ \\
$2-2$ & $5(5,04)$ & $4(4,12)$ & $7(5,67)$ & $4(3,23)$ & $20(17,56)$ \\
$2-3$ & $7(8,25)$ & $12(15,22)$ & $11(15,81)$ & $6(10,10)$ & $36(49,97)$ \\
$2-4$ & $4(2,75)$ & $4(1,27)$ & $5(3,10)$ & $7(4,77)$ & $20(12,16)$ \\
$3-3$ & $4(3,37)$ & $17(14,05)$ & $15(11,02)$ & $10(7,90)$ & $46(35,56)$ \\
$3-4$ & $2(2,25)$ & $0(2,34)$ & $3(4,31)$ & $7(7,46)$ & $12(17,30)$ \\
$4-4$ & $0(0,38)$ & $0(0,10)$ & $0(0,43)$ & $1(1,77)$ & $1(2,10)$ \\
\hline $\mathrm{N}$ & 24 & 41 & 48 & 41 & 154 \\
\hline
\end{tabular}

$\mathrm{N}=$ número de animais analisados em cada amostra:

( ) = valores esperados sob equilíbrio de Hardy-Weinberg. 
Tabela 17. Teste de aderência ao equilíbrio de Hardy-Weinberg para o microssatélite do gene IGF-I.

\begin{tabular}{|c|c|c|c|c|c|}
\hline \multirow[b]{2}{*}{ Genótipos $^{\mathrm{a}}$} & \multicolumn{4}{|c|}{ Classes } & \multirow[b]{2}{*}{ Total } \\
\hline & $\mathrm{G}_{3}$ & $\mathrm{G}_{4}$ & $\mathrm{G}_{5}$ & $\mathrm{G}_{6}$ & \\
\hline \multicolumn{6}{|l|}{ Homozigotos mais } \\
\hline frequentes & $5(5,04)$ & $17(14,05)$ & $15(11,02)$ & $10(7,90)$ & $46(35,56)$ \\
\hline \multicolumn{6}{|l|}{ Heterozigotos mais } \\
\hline frequentes & $12(11,92)$ & $14(20,00)$ & $16(23,96)$ & $16(20,20)$ & $56(76,88)$ \\
\hline \multicolumn{6}{|l|}{ Homozigotos e } \\
\hline heterozigotos raros & $7(7,04)$ & $10(7,05)$ & $17(13,02)$ & $15(12,90)$ & $52(41,56)$ \\
\hline $\mathrm{N}$ & 24 & 41 & 48 & 41 & 154 \\
\hline$\chi^{2}, \mathrm{GL}=1$ & 0,999 & 3,606 & $5,296^{*}$ & 1,769 & $11,362 * *$ \\
\hline
\end{tabular}

${ }^{a} \mathrm{Na}$ classe $\mathrm{G}_{3} \mathrm{o}$ alelo mais frequente foi o alelo 2, nas demais classes $\mathrm{o}$ alelo 3 foi $\mathrm{o}$ mais frequente; ( ) Valores esperados sob equilíbrio de Hardy-Weinberg;

* Significativo a 5\%; $* *$ Significativo a $1 \%$.

Observa-se que apenas na amostra da geração 5 e no total da população os desvios em relação às proporções de equilíbrio foram significativos. Os valores do coeficiente de fixação de Wright (F) para todas as classes foram positivos (Tabela 18), indicando que o desequilíbrio é resultante de um excesso de homozigotos. Esse excesso não foi tão pronunciado quanto aquele observado para o loco $\mathrm{GH}$. $\mathrm{O}$ excesso de homozigotos pode ser atribuído a alguns fatores, entre eles a endogamia e a seleção. A endogamia calculada pelo pedigri e com base em marcadores será discutida em mais detalhes no decorrer dessa seção. Entretanto, é interessante para a compreensão desses resultados ressaltar que a média de endogamia do total da amostra foi inferior a $1 \%$ e que a maior média observada foi a da classe $G_{5}(1,4 \%)$. 
Tabela 18. Coeficientes de fixação de Wright (F) para o microssatélite IGF-I.

\begin{tabular}{cccc}
\hline Classe & Ho & He & $F$ \\
\hline $\mathrm{G}_{3}$ & 15 & 15,17 & 0,011 \\
$\mathrm{G}_{4}$ & 20 & 22,63 & 0,116 \\
$\mathrm{G}_{5}$ & 25 & 30,55 & 0,182 \\
$\mathrm{G}_{6}$ & 26 & 27,89 & 0,068 \\
\hline Total & 86 & 98,13 & 0,124 \\
\hline
\end{tabular}

$\mathrm{Ho}=$ Heterozigotos observados; $\mathrm{He}=$ Heterozigotos esperados sob equilíbrio. $\mathrm{F}=1-\mathrm{Ho} / \mathrm{He}$.

Os resultados das análises do microssatélite IGF-I sugerem que um ou mais fatores contrários às condições de equilíbrio de Hardy-Weinberg influenciaram a distribuição das frequências gênicas. A ausência de linearidade no aumento da frequência do alelo 4 desse marcador pode ser decorrente de efeitos de deriva ou do efeito conjunto de deriva e seleção. Essa última hipótese é aceitável se considerarmos um efeito pequeno desse marcador sobre as características fenotípicas selecionadas ou de ligação a um QTL relativamente distante no cromossomo. A confirmação da hipótese de seleção requer a análise de associação desse alelo com características de produção. Na raça Hereford, Moody et al. (1994) verificaram efeitos significativos e positivos da substituição de alelos na DEP para peso ao nascimento, peso à desmama e a um ano de idade. Naquele estudo, os primers desenvolvidos por Kirkpatrick (1992) foram utilizados. Esses primers correspondem a uma região mais próxima da sequência repetitiva de tal forma que não foi possível estabelecer uma relação entre os alelos A (130 pb) e B (128 pb) descritos por Moody et al. (1994) e os observados no presente trabalho. Estudos preliminares sobre a associação entre os genótipos de IGF-I e performance em provas de ganho de peso de 48 animais da raça Nelore foram realizados por Rosa et al. (1996). Nessa raça, apenas os alelos 2 e 4 foram observados para esse marcador, tendo sido o alelo 4 predominante, com frequência de 0,738 . As médias de peso ao nascimento, ganho de peso diário e peso 
ajustado para 378 dias foram superiores para os homozigotos para o alelo 4, entretanto essas diferenças não chegaram a ser significativas $(P>0,15)$.

Apenas 3 dos quatro alelos descritos por Bishop et al. (1994) foram observados na raça Charolesa (Tabela 19), correspondendo aos alelos 1, 2 e 3 observados em Canchim.

Tabela 19. Distribuição dos genótipos, frequências gênicas e valor de $\chi^{2}$ para o teste de aderência ao equilíbrio de HW para o microssatélite IGF-I na raça Charolesa.

\begin{tabular}{cccc}
\hline Genótipos & No $(\mathrm{Ne})$ & Alelos $^{\mathrm{a}}$ & Frequências \\
\hline $1-1$ & $1(1,88)$ & $1(231)$ & $0,235 \pm 0,051$ \\
$1-2$ & $13(11,77)$ & & \\
$1-3$ & $1(0,47)$ & $2(229)$ & $0,735 \pm 0,053$ \\
$2-2$ & $18(18,38)$ & & \\
$2-3$ & $1(1,47)$ & $3(227)$ & \\
$3-3$ & $0(0,03)$ & & \\
\hline $\mathrm{N}$ & 34 & & \\
\hline$\chi_{1 \mathrm{GL}}{ }^{(b)}$ & $0,005^{\text {ns }}$ & & \\
\hline
\end{tabular}

${ }^{\mathrm{a}} \mathrm{O}$ tamanho de cada alelo em pares de bases é indicado entre parêntesis.

${ }^{\mathrm{b}}$ Valor obtido após o agrupamento dos alelos 2 e 3; ns= não significativo. $\mathrm{No}=$ Número observado; (Ne) Valores esperados sob equilíbrio de Hardy-Weinberg.

É interessante observar que nos trabalhos conduzidos com raças taurinas, apenas três alelos foram descritos para esse microssatélite (Kirkpatrick, 1994; Moody et al. , 1994). A existência de um quarto alelo foi descrita por Bishop et al. (1994), utilizando cruzamentos entre raças taurinas e zebuínas, entre as quais a raça Nelore estava representada. Esses dados sugerem que os alelos 1, 2 e 3 observados na raça Charolesa, no presente trabalho, correspondem aos alelos de 130, 128 e 126 pares de bases descritos por Kirkpatrick (1994). De acordo com os resultados obtidos no presente trabalho e com 
as observações da literatura apresentadas conclui-se que o alelo 4 observado em Canchim é proveniente de raças zebuínas.

Diante desses fatos, a presença simultânea de variação significativa nos locos GH e microssatélite do gene IGF-I, observada na raça Canchim, merece especial atenção. A variação observada no primeiro sugere o favorecimento de um alelo característico de Charolês e no segundo, de um alelo característico de raças taurinas. Considerando a intensa relação fisiológica entre o hormônio de crescimento e o fator de crescimento IGF-I, os efeitos do aparecimento de novas combinações genotípicas para esses dois genes nos produtos de cruzamento entre raças taurinas e zebuínas podem ser favoráveis.

$\mathrm{O}$ alelo 3 do microssatélite IGF-I foi o menos frequente na raça Charolesa $(0,03)$ tendo sido o alelo predominante na raça Canchim. $\mathrm{Na}$ ausência de informações sobre as frequências gênicas em outras raças zebuínas é impossivel concluir que o alelo 3 não seja encontrado nessas raças. Uma explicação para a discrepância entre as frequências desse alelo nas raças Canchim e Charolesa pode ser o fato de que a amostra da raça Charolesa difere do material genético utilizado na formação do Canchim. Essa hipótese é bastante provável tendo-se em vista que aproximadamente 40 anos de seleção se passaram e que é pouco provável que a raça Charolesa atual seja idêntica à original. Além disso, o tamanho da amostra da raça Charolesa foi reduzido e, portanto, as estimativas de frequência são apenas aproximadas.

\subsection{Microssatélite CSFM50}

O microssatélite CSFM50, localizado no braço longo do cromossomo 2 dos bovinos, foi amplificado com os iniciadores descritos por Moore et al. (1994). O padrão de bandas obtido após a separação dos produtos de amplificação e autorradiografia é apresentado na Figura 8.

Os alelos foram numerados de acordo com a ordem decrescente de tamanho, respeitando-se os intervalos de dois pares de bases. 


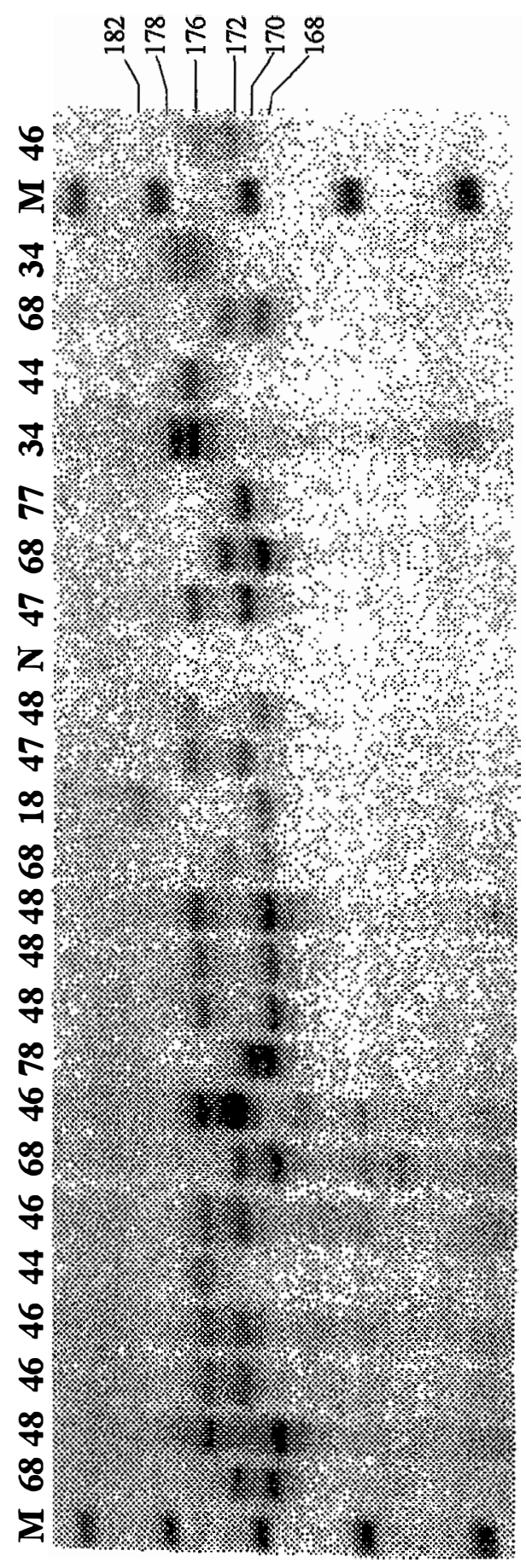

$\infty$

哥

용

.

禺

苛

:

홍으

뽀 임

造 울

胥

ส

क

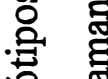

品

O)

ค่

$\sum_{\text {兵 }}$

U

क त

웜

क

惹

웅

总

.

荧

용 중

莺

象 
$\mathrm{Na}$ raça Canchim, seis alelos foram observados. As frequências gênicas são apresentadas na Tabela 20. O comportamento das frequências dos seis alelos ao longo das gerações é ilustrado na Figura 9. Para testar a significância da variação de frequência entre as amostras, calculou-se o valor de qui-quadrado para o teste de independência em tabelas de contingência (Tabela 20). Nesse teste, o total de cada alelo foi testado contra os demais. Dos seis alelos observados para esse marcador, apenas o alelo 8 (168 pb) variou significativamente entre as classes.

Tabela 20. Frequências gênicas para o marcador CSFM50 nas quatro amostras de Canchim e valor de $\chi^{2}$ para o teste de independência.

\begin{tabular}{|c|c|c|c|c|c|c|}
\hline \multirow[b]{2}{*}{ Alelos $^{a}$} & \multicolumn{4}{|c|}{ Classes } & \multirow[b]{2}{*}{ Total } & \multirow[b]{2}{*}{$\chi_{3 \mathrm{GL}}^{2}$} \\
\hline & $\mathrm{G}_{3}$ & $\overline{G_{4}}$ & $\overline{\mathrm{G}_{5}}$ & $\overline{\mathrm{G}_{6}}$ & & \\
\hline $1(182)$ & 0,021 & 0,049 & 0,031 & 0,073 & 0,045 & $4,95^{\mathrm{ns}}$ \\
\hline $3(178)$ & 0,063 & 0,049 & 0,073 & 0,073 & 0,065 & $0,55^{\mathrm{ns}}$ \\
\hline $4(176)$ & 0,354 & 0,512 & 0,323 & 0,402 & 0,399 & $7,10^{\text {ns }}$ \\
\hline $6(172)$ & 0,188 & 0,183 & 0,313 & 0,280 & 0,250 & $5,37^{\text {ns }}$ \\
\hline $7(170)$ & 0,125 & 0,085 & 0,094 & 0,098 & 0,097 & $0,57^{\text {ns }}$ \\
\hline $8(168)$ & 0,250 & 0,122 & 0,167 & 0,073 & 0,143 & $8,49 *$ \\
\hline EP 1 & 0,021 & 0,024 & 0,018 & 0,029 & 0,012 & \\
\hline EP 3 & 0,035 & 0,024 & 0,027 & 0,029 & 0,014 & \\
\hline EP 4 & 0,069 & 0,055 & 0,048 & 0,054 & 0,028 & \\
\hline EP 6 & 0,056 & 0,043 & 0,047 & 0,050 & 0,025 & \\
\hline EP 7 & 0,048 & 0,031 & 0,030 & 0,033 & 0,017 & \\
\hline EP 8 & 0,063 & 0,036 & 0,038 & 0,029 & 0,020 & \\
\hline
\end{tabular}

${ }^{a} O$ tamanho de cada alelo em pares de bases é indicado entre parêntesis.

EP 1 a 8 = Erro padrão da estimativa de frequência dos alelos 1 a 8 , respectivamente. ns= não significativo; $*$ Significativo a $5 \%$. 


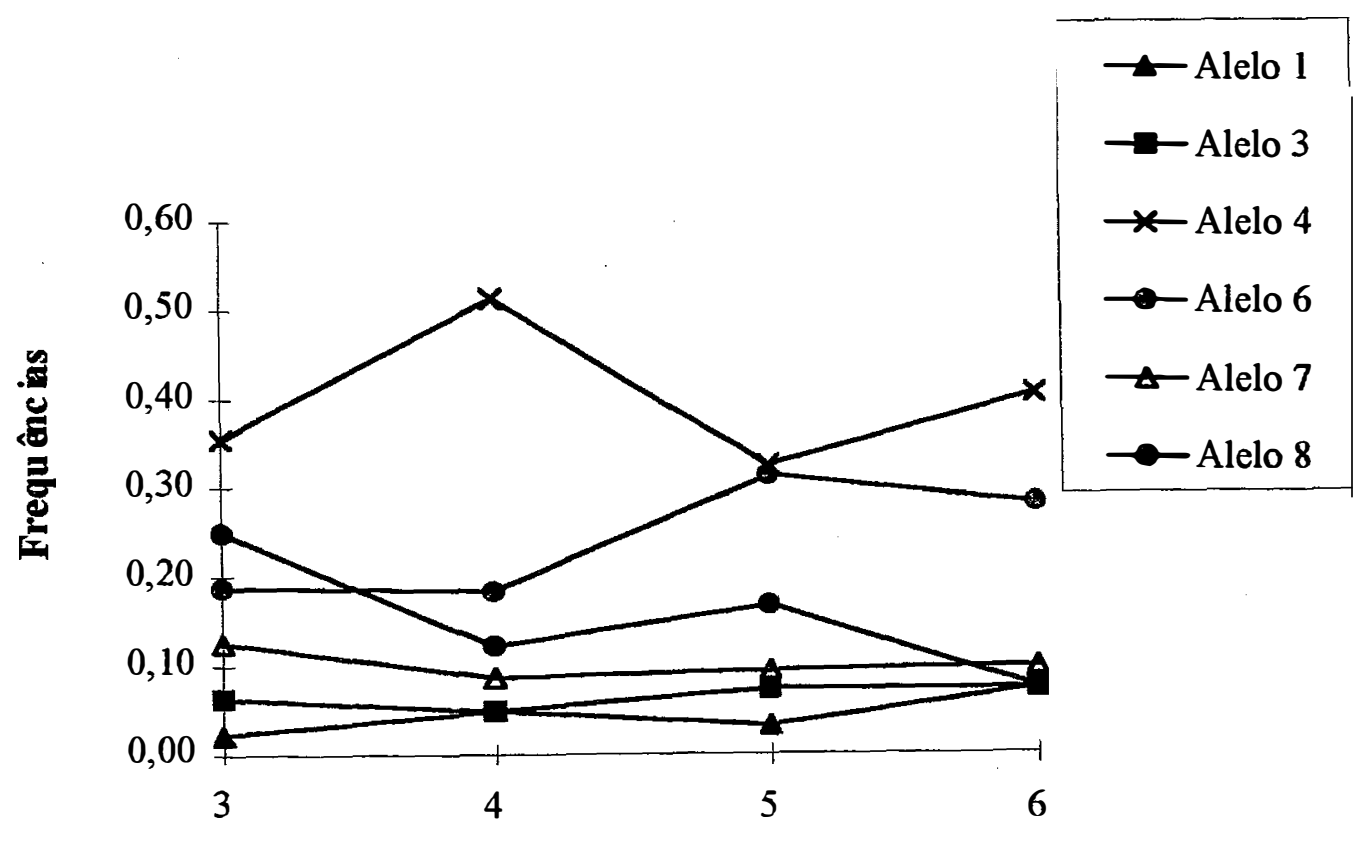

Gerações

Figura 9. Distribuição das frequências dos alelos de CSFM50 nas gerações de Canchim.

Com a finalidade de testar a linearidade da mudança de frequência do alelo 8 , a análise de regressão para proporções foi utilizada, como descrito anteriormente. Os resultados dessa análise estão de acordo com a hipótese de linearidade, tendo-se obtido um coeficiente de regressão negativo de -0,048 (Figura 10).

Tabela 21. Análise de regressão entre as frequências do alelo 8 de CSFM50 e as gerações de Canchim.

$\begin{array}{llll} & \text { GL } & \chi^{2} & \text { P } \\ \text { Regressão } & 1 & 5,11^{*} & 0,02 \\ \text { Desvios da regressão } & 2 & 3,38^{\text {ns }} & 0,18 \\ \text { Total } & 3 & 8,49^{*} & 0,04\end{array}$

$\mathbf{P}=$ probabilidade associada aos valores de $\chi^{2}$.

* Significativo a 5\%; ns = não significativo. 


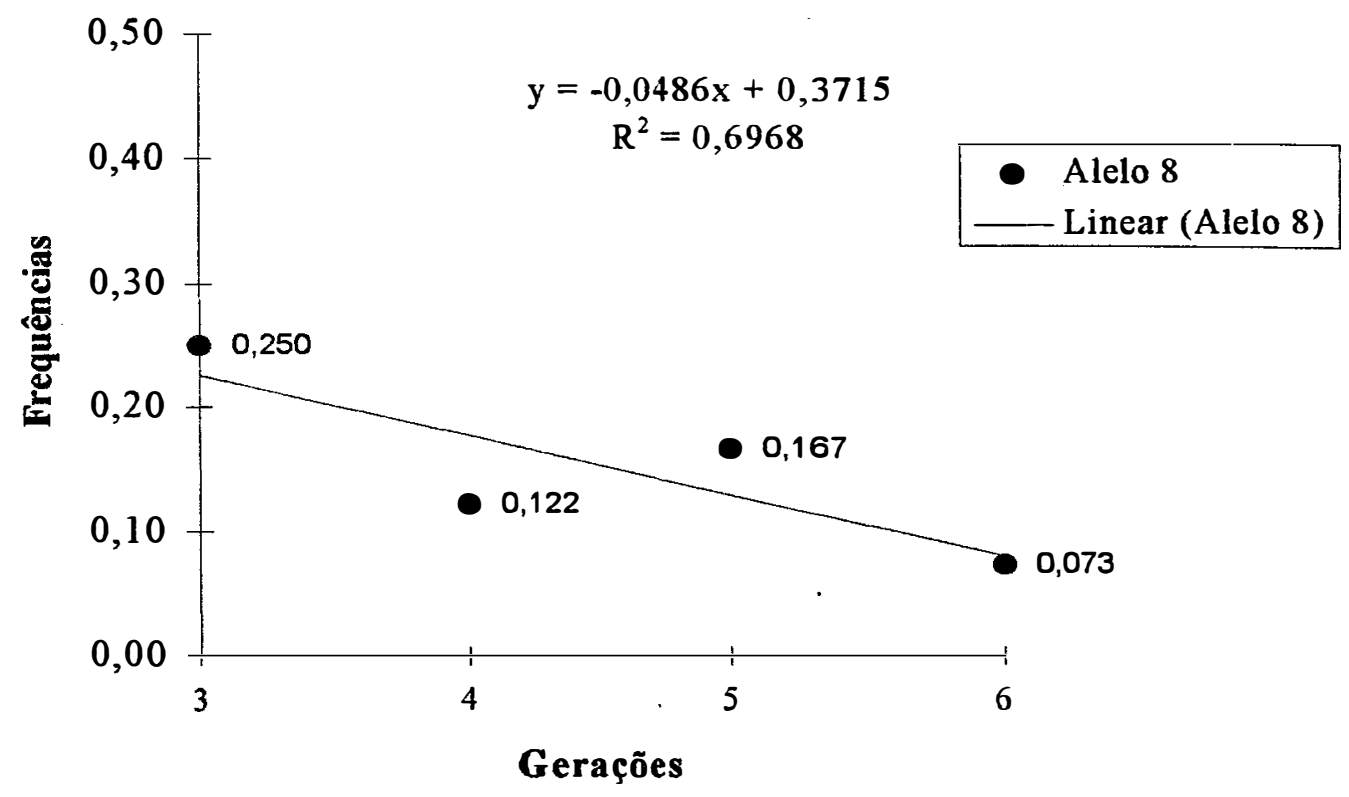

Figura 10. Distribuição das frequências do alelo 8 de CSFM50 ao longo das gerações de Canchim.

A distribuição dos genótipos de CSFM50 na raça Canchim é apresentada na Tabela 22. Devido à baixa frequência de muitas das combinações genotípicas, as classes foram agnupadas em : homozigotos para o alelo mais frequente; heterozigotos para $o$ alelo mais frequente; homozigotos e heterozigotos para os alelos raros. Essas classes foram utilizadas para testar a aderência à hipótese de equilíbrio de Hardy-Weinberg (Tabela 23). 
Tabela 22. Distribuição dos genótipos de CSFM50 nas quatro gerações de Canchim.

\begin{tabular}{|c|c|c|c|c|c|}
\hline \multirow[b]{2}{*}{ Genótipo } & \multicolumn{4}{|c|}{ Classes } & \multirow[b]{2}{*}{ Total } \\
\hline & $\mathrm{G}_{3}$ & $\mathrm{G}_{4}$ & $\mathrm{G}_{5}$ & $\mathrm{G}_{6}$ & \\
\hline $1-1$ & $0(0,01)$ & $0(0,10)$ & $1(0,05)$ & $1(0,22)$ & $2(0,32)$ \\
\hline $1-4$ & $0(0,35)$ & $2(2,05)$ & $0(0,97)$ & $3(2,41)$ & $5(5,59)$ \\
\hline $1-6$ & $0(0,19)$ & $1(0,73)$ & $0(0,94)$ & $1(1,68)$ & $2(3,50)$ \\
\hline $1-7$ & $0(0,13)$ & $1(0,34)$ & $0(0,28)$ & $0(0,58)$ & $1(1,36)$ \\
\hline $1-8$ & $1(0,25)$ & $0(0,49)$ & $1(0,50)$ & $0(0,44)$ & $2(2,00)$ \\
\hline $3-4$ & $2(1,06)$ & $2(2,05)$ & $2(2,26)$ & $2(2,41)$ & $8(7,99)$ \\
\hline $3-6$ & $1(0,56)$ & $0(0,73)$ & $2(2,19)$ & $2(1,68)$ & $5(5,00)$ \\
\hline $3-7$ & $0(0,37)$ & $0(0,34)$ & $1(0,66)$ & $0(0,58)$ & $1(1,95)$ \\
\hline $3-8$ & $0(0,75)$ & $2(0,49)$ & $2(1,17)$ & $2(0,44)$ & $6(2,86)$ \\
\hline $4-4$ & $2(3,01)$ & $11(10,76)$ & $5(5,00)$ & $5(6,64)$ & $23(24,56)$ \\
\hline $4-6$ & $1(3,19)$ & $8(7,68)$ & $10(9,67)$ & $11(9,26)$ & $30(30,75)$ \\
\hline $4-7$ & $4(2,12)$ & $4(3,58)$ & $5(2,91)$ & $5(3,22)$ & $18(11,98)$ \\
\hline $4-8$ & $6(4,25)$ & $4(5,12)$ & $4(5,17)$ & $2(2,41)$ & $16(17,57)$ \\
\hline $6-6$ & $1(0,84)$ & $2(1,37)$ & $5(4,69)$ & $3(3,23)$ & $11(9,57)$ \\
\hline $6-7$ & $0(1,12)$ & $1(1,28)$ & $2(2,81)$ & $2(2,24)$ & $5(7,50)$ \\
\hline $6-8$ & $5(2,25)$ & $1(1,83)$ & $6(5,00)$ & $1(1,68)$ & $13(11,00)$ \\
\hline $7-7$ & $1(0,37)$ & $0(0,30)$ & $0(0,42)$ & $0(0,39)$ & $1(1,46)$ \\
\hline $7-8$ & $0(1,50)$ & $1(0,85)$ & $1(1,50)$ & $1(0,58)$ & $3(4,29)$ \\
\hline $8-8$ & $0(1,50)$ & $i(0,61)$ & $1(1,33)$ & $0(0,22)$ & $2(3,14)$ \\
\hline $\mathbf{N}$ & 24 & 41 & 48 & 41 & 154 \\
\hline
\end{tabular}

$\mathrm{N}=$ Número de animais

( ) = Valores esperados sob equilíbrio de Hardy-Weinberg. 
Tabela 23. Teste de aderência às proporções de equilíbrio de Hardy-Weinberg para o marcador CSFM50 nas quatro gerações de Canchim.

\begin{tabular}{cccccc}
\hline & \multicolumn{5}{c}{ Classes } \\
Genótipos & $\mathrm{G}_{3}$ & $\mathrm{G}_{4}$ & $\mathrm{G}_{5}$ & $\mathrm{G}_{6}$ & Total \\
\hline 44 & $2(3,0)$ & $11(10,8)$ & $5(5,0)$ & $5(6,6)$ & $23(24,6)$ \\
$4 \mathrm{x}$ & $13(11,0)$ & $20(20,5)$ & $21(21,0)$ & $23(19,7)$ & $77(73,9)$ \\
$\mathrm{xx}$ & $9(10,0)$ & $10(9,8)$ & $22(22,0)$ & $13(14,6)$ & $54(55,6)$ \\
\hline $\mathrm{N}$ & 24 & 41 & 48 & 41 & 154 \\
\hline$\chi^{2}, 1 \mathrm{GL}^{\text {a }}$ & $0,570^{\text {ns }}$ & $0,000^{\text {ns }}$ & $0,000^{\text {ns }}$ & $0,677^{\text {ns }}$ & $0,275^{\text {ns }}$ \\
\hline
\end{tabular}

$\mathrm{x}=$ todos os alelos diferentes de 4 ;

${ }^{a}$ Os valores de $\chi^{2}$ para as classes $G_{3}$ a $G_{6}$ foram obtidos com correção de Yates.

De acordo com os resultados dessa análise, as frequências genotípicas observadas não diferem estatísticamente das esperadas sob a hipótese de equilíbrio. Esse resultado é conflitante com os resultados obtidos nas análises de independência e de regressão.

$\mathrm{Na}$ raça Charolesa, os alelos 1 (182 pb) e 7 (170 pb) não foram observados. Entretanto, dois alelos que não haviam sido encontrados na raça Canchim, com tamanhos de $180 \mathrm{pb}$ e $174 \mathrm{pb}$, foram identificados nesses animais. Esses alelos foram denominados alelo 2 e alelo 5, respectivamente. A distribuição dos genótipos de CSFM50 e as frequências dos seis alelos observados na raça Charolesa são apresentadas na Tabela 24.

Para testar a aderência das proporções genotípicas à hipótese de equilíbrio de Hardy-Weinberg, as classes foram agnupadas pelo procedimento descrito anteriormente. Da mesma forma que na raça Canchim, o alelo mais frequente na raça Charolesa foi o alelo 4. O resultado do teste de aderência foi não significativo, aceitando-se, portanto, a hipótese de equilíbrio para a mostra da raça Charolesa. 
Tabela 24. Distribuição dos genótipos, frequências gênicas e valor de $\chi^{2}$ para o teste de aderência ao equilíbrio de HW para o MS - CSFM50 na raça Charolesa.

\begin{tabular}{|c|c|c|c|}
\hline Genótipos & No $(\mathrm{Ne})$ & ${ }^{\mathrm{a}}$ Alelos & Frequências \\
\hline $2-2$ & $0(0,01)$ & $2(180)$ & $0,014 \pm 0,014$ \\
\hline $2-3$ & $0(0,22)$ & & \\
\hline $2-4$ & $1(0,51)$ & & \\
\hline $2-5$ & $0(0,01)$ & & \\
\hline $2-6$ & $0(0,04)$ & & \\
\hline $2-8$ & $0(0,04)$ & & \\
\hline $3-3$ & $2(1,78)$ & $3(178)$ & $0,222 \pm 0,049$ \\
\hline $3-4$ & $8(8,22)$ & & \\
\hline $3-5$ & $0(0,22)$ & & \\
\hline $3-6$ & $4(3,11)$ & & \\
\hline $3-8$ & $0(0,07)$ & & \\
\hline $4-4$ & $9(9,51)$ & $4(176)$ & $0,514 \pm 0,059$ \\
\hline $4-5$ & $1(0,51)$ & & \\
\hline $4-6$ & $7(7,19)$ & & \\
\hline $4-8$ & $2(1,54)$ & & \\
\hline $5-5$ & $0(0,01)$ & $5(174)$ & $0,014 \pm 0,014$ \\
\hline $5-6$ & $0(0,19)$ & & \\
\hline $5-8$ & $0(0,04)$ & & \\
\hline $6-6$ & $1(1,36)$ & $6(172)$ & $0,194 \pm 0,047$ \\
\hline $6-8$ & $1(0,58)$ & & \\
\hline $8-8$ & $0(0,06)$ & $8(170)$ & $0,042 \pm 0,024$ \\
\hline $\bar{N}$ & 36 & & \\
\hline$\chi^{2}{ }_{1 \mathrm{GL}}{ }^{(\mathrm{b})}$ & $0,114^{\text {ns }}$ & & \\
\hline
\end{tabular}

${ }^{\mathrm{a}} \mathrm{O}$ tamanho de cada alelo em pares de bases é indicado entre parêntesis.

${ }^{\mathrm{b}}$ Valor obtido após o agrupamento das classes menos frequentes; ns= não significativo. $\mathrm{No}=$ Número observado; (Ne) Valores esperados sob equilíbrio de Hardy-Weinberg. 
Na raça Nelore, Rosa et al. (1996) observaram 5 alelos para o microssatélite CSFM50, correspondentes aos alelos 3, 4, 6, 7 e 8 descritos no presente trabalho. Naquela raça, o alelo 8 foi o mais frequente $(0,317)$, seguido pelos alelos $4,6,7$ e 2 , em ordem decrescente de frequência.

A região do cromossomo 2 dos bovinos, na qual o microssatélite CSFM50 foi mapeado, foi associada à características de peso da desmama até a maturidade, em famílias de referência utilizadas no programa ANGLETON de mapeamento genético dos bovinos (Davis \& Taylor, 1995). Os resultados obtidos na análise de regressão do total de alelos 8 sobre as gerações de Canchim indicaram uma tendência linear de redução da frequência desse alelo ao longo do tempo (gerações). A hipótese de seleção não foi confirmada pela análise de aderência ao equilíbrio de Hardy-Weinberg. De acordo com a teoria de Hardy-Weinberg, em presença de equilíbrio as frequências gênicas devem se manter constantes de uma geração para a outra. Uma possível explicação para a observação simultânea de equilíbrio e variação de frequência gênica é a ocorrência de seleção ou deriva de um modo descontínuo. Quando algum fator contrário às condições de equilíbrio afeta a população, alterando as frequências gênicas, as proporções genotípicas de equilíbrio para as novas frequências gênicas podem ser restabelecidas após um ciclo de acasalamento ao acaso. Dessa forma, se os fatores envolvidos na alteração de frequência do alelo 8 não ocorressem em todos os ciclos de reprodução, a verificação de equilíbrio seria esperada. A variação significativa da frequência do alelo 8 pode também ter sido decorrente de deriva em função tanto da amostragem dos gametas durante a formação das gerações quanto da análise de um número limitado de animais por geração. Entretanto, nessa situação, a ocorrência de uma variação linear seria pouco provável.

Outro fato interessante com relação aos resultados obtidos na raça Canchim foi que a variação de frequência foi significativa apenas para o alelo 8 . Se esse polimorfismo resultasse em alterações do produto gênico, seria possível admitir a vantagem seletiva de um alelo especificamente. Entretanto, tratando-se de uma sequência não codificadora, esse argumento é pouco provável. A vantagem seletiva nesse caso seria mais 
provavelmente resultante de ligação a um ou mais QTLs muito próximos, de tal forma que o alelo 8 estaria sempre ligado ao QTL desfavorável. A análise da relação entre esse marcador e características de produção poderia ser útil para a compreensão desses resultados. A inclusão de outros marcadores estreitamente ligados a esse loco, de modo a obter haplótipos, poderia ser empregada em análises de famílias de touros para identificar a origem do provável QTL com relação a algum reprodutor ancestral.

\subsection{Microssatélite BM1224}

O loco microssatélite BM1224, localizado no cromossomo 4 dos bovinos, foi amplificado com os iniciadores descritos por Bishop et al. (1994). O padrão de bandas obtido após a eletroforese em gel de poliacrilamida desnaturante e autorradiografia é apresentado na Figura 11.

Os alelos foram numerados em ordem decrescente de tamanho, respeitando-se os intervalos de dois pares de bases. Os alelos $1 ; 2 ; 4 ; 6 ; 7$ e 8 foram observados na raça Canchim. Os tamanhos estimados desses alelos, bem como as frequências gênicas nas quatro amostras do rebanho Canchim são apresentados na Tabela 25.

A significância da variação de frequência entre as gerações foi verificada pelo teste de independência entre o total de cada alelo contra os demais. Apenas três dos seis alelos foram testados em consequência da baixa frequência dos demais (Tabela 25). 


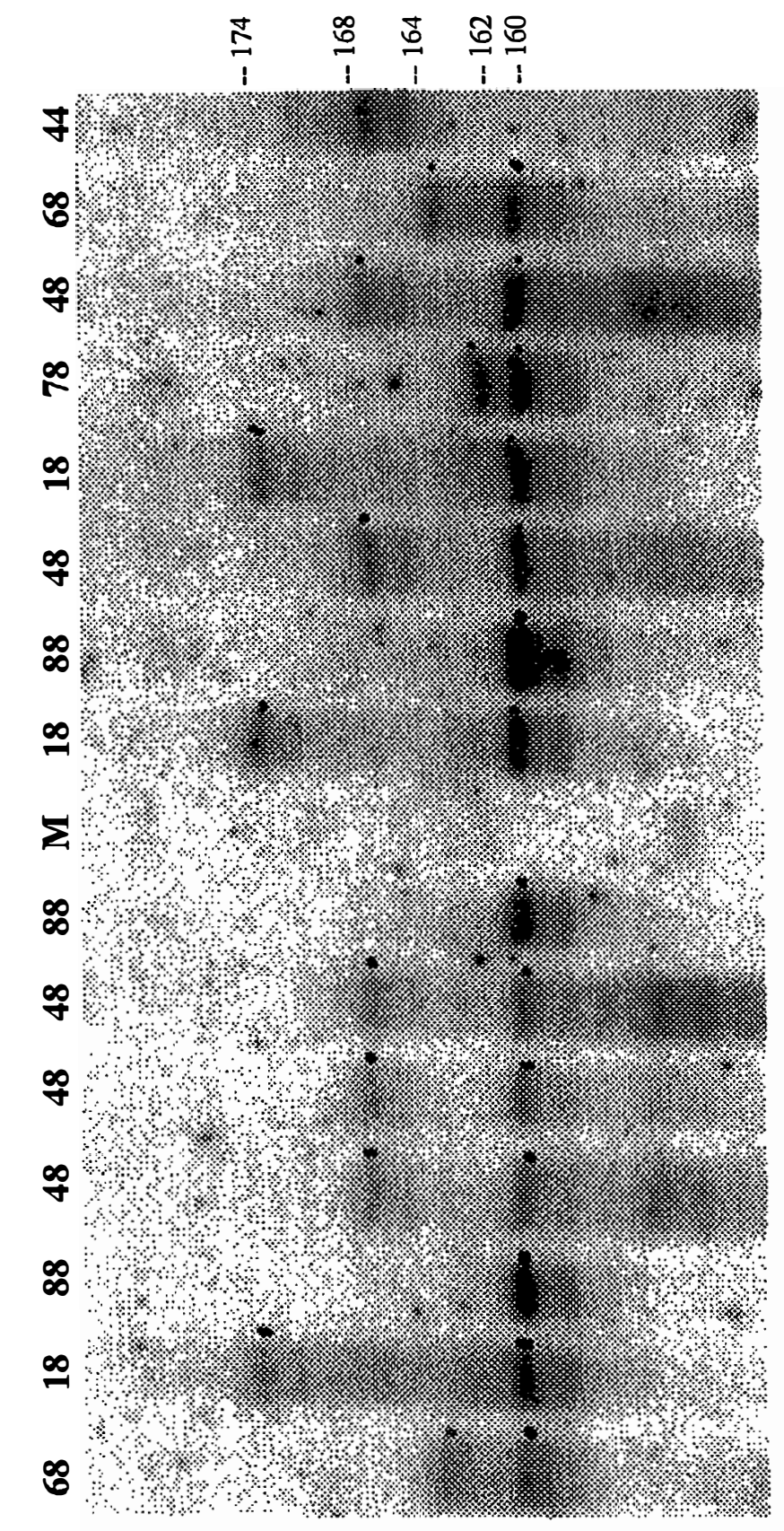

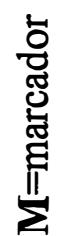

을

응

옥

స్్ㅀ్ㅀ

胥

징

윯

웅

芯 畩

ه

임

ஜ 즁

껸

通

융

总

ㅇํㅁ욤

苞

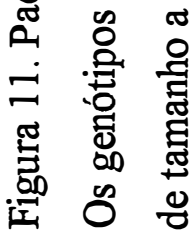


Tabela 25. Frequências dos alelos de BM1224 nas gerações de Canchim e valores de $\chi^{2}$ para o teste de independência.

\begin{tabular}{|c|c|c|c|c|c|c|}
\hline \multirow[b]{2}{*}{ Alelos $^{\mathrm{a}}$} & \multicolumn{4}{|c|}{ Classes } & \multirow[b]{2}{*}{ Total } & \multirow[b]{2}{*}{$\chi_{3 \mathrm{GL}}^{2}$} \\
\hline & $\mathrm{G}_{3}$ & $\mathrm{G}_{4}$ & $\mathrm{G}_{5}$ & $\mathrm{G}_{6}$ & & \\
\hline $1(174)$ & 0,104 & 0,195 & 0,240 & 0,195 & 0,195 & $3,74^{\mathrm{ns}}$ \\
\hline $2(172)$ & 0,042 & 0,024 & 0,010 & 0,024 & 0,023 & NT \\
\hline $4(168)$ & 0,375 & 0,317 & 0,208 & 0,256 & 0,276 & $5,41^{\mathrm{ns}}$ \\
\hline $6(164)$ & 0,000 & 0,073 & 0,073 & 0,085 & 0,065 & NT \\
\hline $7(162)$ & 0,042 & 0,012 & 0,031 & 0,049 & 0,032 & NT \\
\hline $8(160)$ & 0,438 & 0,378 & 0,438 & 0,390 & 0,409 & $4,31^{n}$ \\
\hline EP 1 & 0,044 & 0,044 & 0,044 & 0,044 & 0,023 & \\
\hline EP 2 & 0,029 & 0,017 & 0,010 & 0,017 & 0,008 & \\
\hline EP 4 & 0,070 & 0,051 & 0,041 & 0,048 & 0,025 & \\
\hline EP 6 & 0,000 & 0,029 & 0,027 & 0,031 & 0,014 & \\
\hline EP 7 & 0,029 & 0,012 & 0,018 & 0,024 & 0,010 & \\
\hline EP 8 & 0,072 & 0,054 & 0,051 & 0,054 & 0,028 & \\
\hline
\end{tabular}

${ }^{\text {a }} \mathrm{O}$ tamanho de cada alelo em pares de bases é indicado entre parêntesis. EP 1 a 8 = Erro-padrão da estimativa de frequência dos alelos 1 a 8, respectivamente. NT = não testado; ns = não significativo.

Os resultados obtidos nos testes de independência sugerem que a variação de frequência estimada nas quatro gerações de Canchim foi aleatória para todos os alelos testados. 
A distribuição dos genótipos de BM1224 nas quatro gerações de Canchim encontra-se na Tabela 26. Em consequência do número de combinações genotípicas observadas e da baixa frequência de três dos seis alelos observados nessa população, 0 teste de aderência às proporções de equilíbrio de Hardy-Weinberg foi realizado após a reunião das classes de menor frequência. Nesse loco, o alelo mais frequente foi o alelo 8 (160 pb). As classes foram constituídas de: homozigotos para o alelo 8; heterozigotos para o alelo 8 e homozigotos e heterozigotos para os demais alelos. Os valores de $\chi^{2}$ obtidos em cada amostra não foram significativos (Tabela 27). Dessa forma, a hipótese de equilíbrio para o loco BM1224 na população Canchim foi aceita para todas as amostras, com exceção da primeira $\left(\mathrm{G}_{3}\right)$. Apesar do reduzido número de animais observados nessa classe, a significância desse teste foi reforçada pelo cálculo da probabilidade exata para a hipótese de equilíbrio de Hardy-Weinbergh (Tabela 27). Como discutido anteriormente, a classe $\mathrm{G}_{3}$ não representa uma amostra aleatória das gerações inferiores a 3,51. Sendo assim, a existência de desequilíbrio nessa classe isoladamente não foi considerada uma evidência conclusiva.

A ausência de variação significativa das frequências gênicas em relação às gerações e a aderência ao equilíbrio de Hardy-Weinberg são indicativos de que esse marcador se comporta como um polimorfismo fenotipicamente neutro e que os efeitos das restrições impostas às exigências de equilíbrio, frequentemente presentes em populações domésticas, acabam por se anular. Esses resultados estão de acordo com o esperado, uma vez que nenhuma evidência de associação com características fenotípicas foi encontrada na literatura para esse marcador. 
Tabela 26 . Distribuição dos genótipos de BM1224 nas gerações de Canchim

\begin{tabular}{|c|c|c|c|c|c|}
\hline \multirow[b]{2}{*}{ Genótipo } & \multicolumn{4}{|c|}{ Classes } & \multirow[b]{2}{*}{ Total } \\
\hline & $\mathrm{G}_{3}$ & $\mathrm{G}_{4}$ & $\mathrm{G}_{5}$ & $\mathrm{G}_{6}$ & \\
\hline $1-1$ & $0(0,26)$ & $0(1,56)$ & $4(2,75)$ & $0(1,56)$ & $4(5,84)$ \\
\hline $1-2$ & $1(0,21)$ & $1(0,39)$ & $1(0,24)$ & $1(0,39)$ & $4(1,36)$ \\
\hline $1-4$ & $1(1,87)$ & $8(5,07)$ & $2(4,80)$ & $2(4,10)$ & $13(16,56)$ \\
\hline $1-6$ & $0(0,00)$ & $1(1,17)$ & $1(1,68)$ & $1(1,37)$ & $3(3,90)$ \\
\hline $1-7$ & $0(0,21)$ & $0(0,19)$ & $0(0,72)$ & $1(0,78)$ & $1(1,95)$ \\
\hline $1-8$ & $3(2,19)$ & $6(6,05)$ & $11(10,06)$ & $11(6,24)$ & $31(24,54)$ \\
\hline $2-4$ & $1(0,75)$ & $1(0,63)$ & $0(0,21)$ & $0(0,51)$ & $2(1,93)$ \\
\hline $2-7$ & $0(0,08)$ & $0(0,02)$ & $0(0,03)$ & $1(0,10)$ & $1(0,23)$ \\
\hline $4-4$ & $6(3,37)$ & $3(4,12)$ & $3(2,08)$ & $4(2,69)$ & $16(11,73)$ \\
\hline $4-6$ & $0(0,00)$ & $0(1,90)$ & $1(1,46)$ & $1(1,79)$ & $2(5,52)$ \\
\hline $4-7$ & $0(0,75)$ & $0(0,32)$ & $1(0,62)$ & $1(1,02)$ & $2(2,76)$ \\
\hline $4-8$ & $4(7,87)$ & $11(9,83)$ & $10(8,75)$ & $9(8,19)$ & $34(34,77)$ \\
\hline $6-6$ & $0(0,00)$ & $2(0,22)$ & $1(0,25)$ & $2(0,30)$ & $5(0,65)$ \\
\hline $6-8$ & $0(0,00)$ & $1(2,27)$ & $3(3,06)$ & $1(2,73)$ & $5(8,18)$ \\
\hline $7-7$ & $1(0,04)$ & $0(0,06)$ & $1(0,05)$ & $0(0,10)$ & $2(0,16)$ \\
\hline $7-8$ & $0(0,87)$ & $1(0,38)$ & $0(1,31)$ & $1(1,56)$ & $2(4,09)$ \\
\hline $8-8$ & $7(4,59)$ & $6(5,86)$ & $9(9,19)$ & $5(6,24)$ & $27(25,77)$ \\
\hline $\mathrm{N}$ & 24 & 41 & 48 & 41 & 154 \\
\hline
\end{tabular}

$\mathrm{N}=$ Número de animais analisados.

( ) = Valores esperados sob equilíbrio de Hardy-Weinberg. 
Tabela 27. Teste de aderência às proporções de equilíbrio de Hardy-Weinberg para 0 marcador BM1224 nas quatro gerações de Canchim.

\begin{tabular}{cccccc}
\hline & \multicolumn{5}{c}{ Gerações } \\
\cline { 2 - 5 } Genótipos $^{\mathrm{a}}$ & $\leq 3$ & 4 & 5 & 6 & Total \\
\hline 88 & $7(4,59)$ & $6(7,85)$ & $9(9,19)$ & $5(7,85)$ & $27(29,48)$ \\
$8 \mathrm{x}$ & $7(11,81)$ & $19(20,18)$ & $24(23,63)$ & $22(20,18)$ & $72(75,80)$ \\
$\mathrm{XX}$ & $10(7,59)$ & $16(12,97)$ & $15(15,19)$ & $14(12,97)$ & $55(48,73)$ \\
\hline $\mathrm{N}$ & 24 & 41 & 48 & 41 & 154 \\
\hline$\chi^{2}, \mathrm{GL}=1$ & $3,98^{*}$ & 1,210 & 0,012 & 1,279 & 1,206 \\
\hline $\mathrm{P}$ & 0,049 & & & & \\
\hline
\end{tabular}

${ }^{a}$ As classes de menor frequência foram agrupadas. $\mathrm{x}=$ Todos os alelos diferentes de 8 .

"Significativo, $\mathrm{P}<0,05 . \mathrm{P}=$ probabilidade obtida pelo teste exato.

Além dos seis alelos observados na população Canchim, a amostra da raça Charolesa apresentou três alelos adicionais, com tamanhos de 178 pb, 176 pb e 166 pb. Esses alelos foram denominados alelos $-2,-1$ e 5 , respectivamente. Em consequência do reduzido número de animais analisados, muitas das combinações genotípicas esperadas não foram observadas. Com a finalidade de simplificar a apresentação dos resultados essas combinações foram consideradas como genótipos raros (Tabela 28). $\mathrm{O}$ teste de aderência ao equilíbrio de Hardy-Weinberg foi realizado após o agrupamento das classes em : homozigotos para o alelo 4; heterozigotos para o alelo 4 ; homozigotos e heterozigotos para os demais alelos. $O$ valor de $\chi^{2}$ obtido nesse teste não foi significativo, tendo sido aceita, portanto, a hipótese de equilíbrio. Os três alelos que foram identificados exclusivamente na raça Charolesa apresentaram frequências menores do que 0,05. Com uma frequência dessa ordem é possível que esses alelos não estivessem representados no material genético utilizado na formação do Canchim. Por outro lado, se a frequência nesse material genético fosse semelhante à observada nessa amostra de Charolês, a população Canchim teria iniciado com frequências inferiores a 0,031 . Nesse 
caso a perda desses alelos no decorrer do tempo ou durante as amostragens seria aceitável.

Tabela 28. Distribuição dos genótipos observados, frequências gênicas e valor de $\chi^{2}$ para o teste de equilíbrio de H.W. para o marcador BM1224 na raça Charolesa.

\begin{tabular}{|c|c|c|c|}
\hline Genótipos & $\mathrm{No}(\mathrm{Ne})$ & Alelos $^{\mathrm{a}}$ & Frequências \\
\hline $1 / 1$ & $2(0,44)$ & $-2(178)$ & $0,014 \pm 0,014$ \\
\hline$-2 / 1$ & $1(0,11)$ & $-1(176)$ & $0,042 \pm 0,024$ \\
\hline $1 / 4$ & $3(3,33)$ & $1(174)$ & $0,111 \pm 0,037$ \\
\hline $2 / 2$ & $1(0,69)$ & $2(172)$ & $0,139 \pm 0,040$ \\
\hline $2 / 4$ & $3(4,17)$ & $4(168)$ & $0,417 \pm 0,058$ \\
\hline $2 / 5$ & $1(0,28)$ & $5(166)$ & $0,028 \pm 0,019$ \\
\hline $2 / 6$ & $3(1,81)$ & $6(164)$ & $0,181 \pm 0,045$ \\
\hline $2 / 7$ & $1(0,28)$ & $7(162)$ & $0,028 \pm 0,019$ \\
\hline $4 / 4$ & $9(6,25)$ & $8(160)$ & $0,042 \pm 0,024$ \\
\hline $4 / 6$ & $4(5,42)$ & & \\
\hline $4 / 8$ & $2(1,25)$ & & \\
\hline $5 / 6$ & $1(0,36)$ & & \\
\hline $6 / 6$ & $1(1,17)$ & & \\
\hline $6 / 8$ & $1(0,54)$ & & \\
\hline$-1 / 6$ & $2(0,54)$ & & \\
\hline$-1 / 7$ & $1(0,08)$ & & \\
\hline Genótipos Raros & $0(9,28)$ & & \\
\hline $\mathrm{N}$ & 36 & & \\
\hline$\chi^{2}{ }_{1 \mathrm{GL}}{ }^{(\mathrm{b})}$ & $2,652^{\mathrm{ns}}$ & & \\
\hline
\end{tabular}

${ }^{\mathrm{a}} \mathrm{O}$ tamanho de cada alelo em pares de bases é indicado entre parêntesis.

${ }^{\mathrm{b}}$ Valor obtido após o agrupamento das classes menos frequentes; ns= não significativo. $\mathrm{No}=$ Número observado; (Ne) Valores esperados sob equilíbrio de Hardy-Weinberg. 


\subsection{Microssatélite INRA006}

Uma repetição de dinucleotídeos $\mathrm{CA}$, localizada no braço longo do cromossomo 3 dos bovinos, foi amplificada com os "iniciadores" descritos por Vaiman et al. (1995). 0 padrão de bandas obtido após a separação dos produtos de amplificação sob condições desnaturantes e autorradiografia é apresentado na Figura 12.

Observa-se que esse marcador apresentou um intenso padrão de bandas acessórias. Esse fato é bastante comum em amplificações de locos microssatélites e resulta, provavelmente, do deslizamento da Taq DNA polimerase durante a amplificação. 0 aparecimento de bandas acessórias dificulta a identificação dos alelos em estudos de populações nos quais não se dispõe de famílias para a análise de segregação.

No presente estudo, a identificação das bandas principais foi feita com base na intensidade da banda e na análise de segregação em farmilias de meios-irmãos patemos. Essas famílias eram provenientes de outros rebanhos, que haviam sido utilizadas em estudos do Laboratório de Biotecnologia Animal da ESALQ / USP. As bandas que não apresentaram padrão de herança consistente foram eliminadas da análise.

Sete alelos foram observados na raça Canchim, com tamanhos entre 119 e 97 pares de bases. Esses alelos foram numerados em ordem decrescente de tamanho, respeitando os intervalos de dois pares de bases. Os alelos com tamanho superior ao do alelo identificado

como alelo 1 receberam números negativos. Dessa forma, o alelo INRA6 _ -3 corresponde ao produto de amplificação com seis pares de bases a mais do que o alelo INRA6 _ 1.

As frequências gênicas estimadas para as amostras de Canchim são apresentadas na Tabela 29. Os testes de independência entre as frequências observadas e as gerações foram realizados com o total de cada alelo contra os demais. Em consequência da baixa frequência, apenas três dos sete alelos foram testados (Tabela 29). 


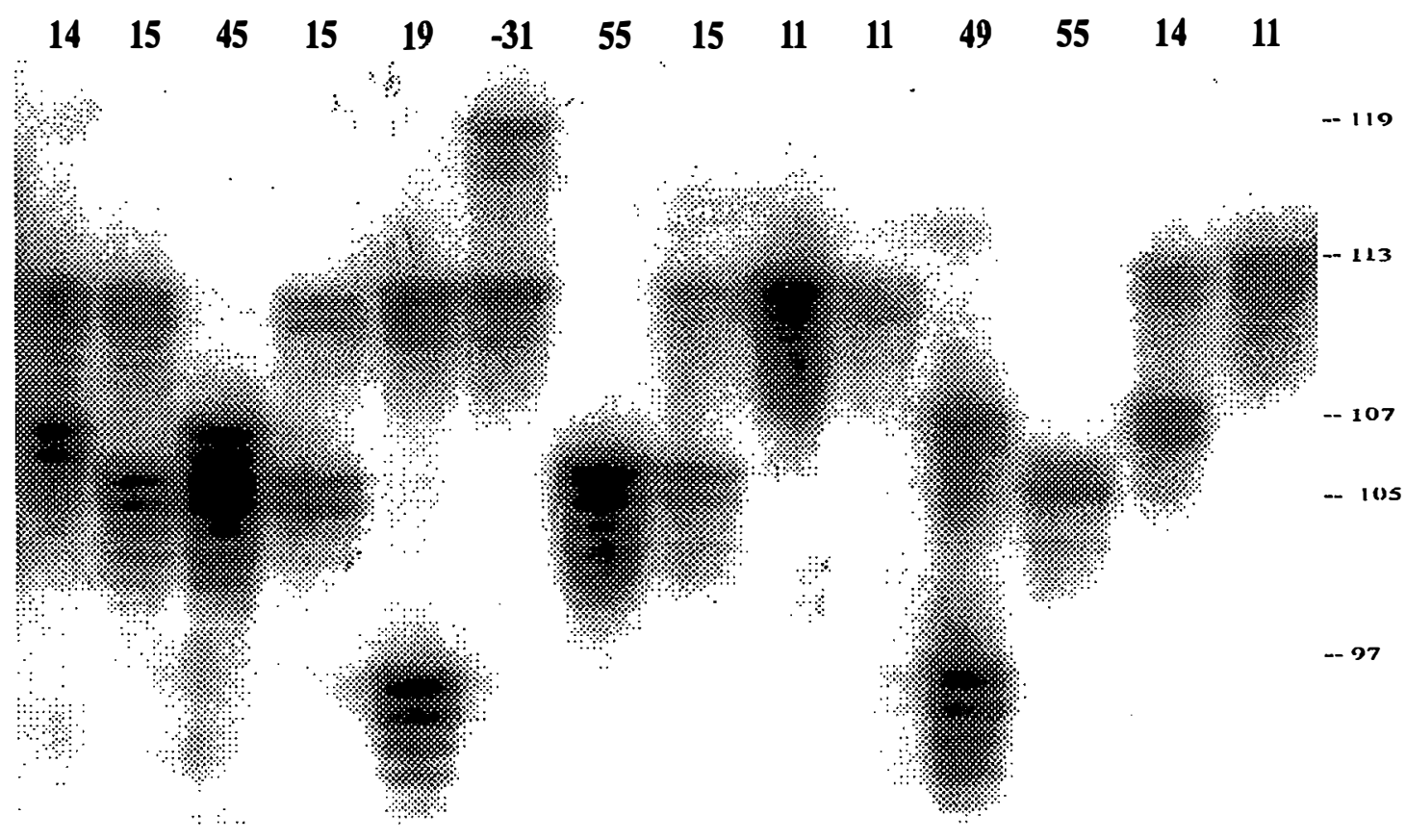

Figura 12. Padrão de bandas observado para o microssatélite INRA006. Os genótipos são indicados na parte superior da figura. Os números ao lado da figura indicam o tamanho dos alelos. 
Tabela 29. Frequências gênicas estimadas, erros-padrões e valores de $\chi^{2}$ para o teste de independência para o marcador INRA006 nas quatro gerações de Canchim.

\begin{tabular}{|c|c|c|c|c|c|c|}
\hline \multirow[b]{2}{*}{ Alelos $^{a}$} & \multicolumn{4}{|c|}{ Classes } & \multirow[b]{2}{*}{ Total } & \multirow[b]{2}{*}{$\chi_{3 \mathrm{GL}}^{2}$} \\
\hline & $\mathrm{G}_{3}$ & $\mathrm{G}_{4}$ & $G_{5}$ & $\mathrm{G}_{6}$ & & \\
\hline$-3(119)$ & 0 & 0,012 & 0 & 0 & 0,003 & NT \\
\hline $1(113)$ & 0,271 & 0,317 & 0,313 & 0,341 & 0,315 & $0,705^{\mathrm{ns}}$ \\
\hline $2(111)$ & 0,021 & 0,000 & 0,042 & 0,024 & 0,023 & NT \\
\hline 3 (109) & 0,042 & 0,012 & 0,021 & 0,037 & 0,026 & NT \\
\hline $4(107)$ & 0,229 & 0,268 & 0,240 & 0,146 & 0,221 & $3,934^{\mathrm{ns}}$ \\
\hline $5(105)$ & 0,438 & 0,366 & 0,385 & 0,451 & 0,406 & $1,610^{\mathrm{ns}}$ \\
\hline $9(97)$ & 0 & 0,024 & 0 & 0 & 0,006 & NT \\
\hline$E P-3$ & 0,000 & 0,012 & 0,000 & 0,000 & 0,003 & \\
\hline EP 1 & 0,064 & 0,051 & 0,047 & 0,052 & 0,026 & \\
\hline EP 2 & 0,021 & 0,000 & 0,020 & 0,017 & 0,008 & \\
\hline EP 3 & 0,029 & 0,012 & 0,015 & 0,021 & 0,009 & \\
\hline EP 4 & 0,061 & 0,049 & 0,044 & 0,039 & 0,024 & \\
\hline EP 5 & 0,072 & 0,053 & 0,050 & 0,055 & 0,028 & \\
\hline EP 9 & 0,000 & 0,017 & 0,000 & 0,000 & 0,005 & \\
\hline
\end{tabular}

${ }^{a} O$ tamanho de cada alelo é indicado entre parêntesis

NT = não testado; ns = não significativo; EP -3 a 9 = Erro-padrão das estimativas de frequência dos alelos -3 a 9 , respectivamente.

Os resultados dos testes de independência sugerem que a variação dos alelos mais frequentes foi aleatória, ou seja, que não existe uma associação entre frequência gênica e geração para esses alelos. A distribuição dos genótipos de INRA006 nas amostras de Canchim encontra-se na Tabela 30. 
Tabela 30: Distribuição dos genótipos do marcador INRA006 nas quatro amostras de Canchim

\begin{tabular}{cccccc}
\hline & \multicolumn{5}{c}{ Classes } \\
\cline { 2 - 5 } Genótipo & $\mathrm{G}_{3}$ & $\mathrm{G}_{4}$ & $\mathrm{G}_{5}$ & $\mathrm{G}_{6}$ & Total \\
\hline$-3-1$ & $0(0,00)$ & $1(0,32)$ & $0(0,00)$ & $0(0,00)$ & $1(0,31)$ \\
$1-1$ & $0(1,76)$ & $5(4,12)$ & $4(4,69)$ & $2(4,78)$ & $11(15,27)$ \\
$1-2$ & $1(0,27)$ & $0(0,00)$ & $4(1,25)$ & $2(0,68)$ & $7(2,20)$ \\
$1-3$ & $0(0,54)$ & $1(0,32)$ & $1(0,62)$ & $2(1,02)$ & $4(2,52)$ \\
$1-4$ & $4(2,98)$ & $5(6,98)$ & $3(7,19)$ & $6(4,10)$ & $18(21,42)$ \\
$1-5$ & $8(5,70)$ & $8(9,51)$ & $14(11,56)$ & $14(12,63)$ & $44(39,37)$ \\
$1-9$ & $0(0,00)$ & $1(0,63)$ & $0(0,00)$ & $0(0,00)$ & $1(0,63)$ \\
$3-4$ & $0(0,46)$ & $0(0,27)$ & $1(0,48)$ & $0(0,44)$ & $1(1,77)$ \\
$3-5$ & $2(0,87)$ & $0(0,37)$ & $0(0,77)$ & $1(1,35)$ & $3(3,25)$ \\
$4-4$ & $0(1,26)$ & $3(2,95)$ & $3(2,75)$ & $0(0,88)$ & $6(7,51)$ \\
$4-5$ & $7(4,81)$ & $10(8,05)$ & $13(8,86)$ & $6(5,41)$ & $36(27,60)$ \\
$4-9$ & $0(0,00)$ & $1(0,54)$ & $0(0,00)$ & $0(0,00)$ & $1(0,44)$ \\
$5-5$ & $2(4,59)$ & $6(5,49)$ & $5(7,13)$ & $8(8,35)$ & $21(25,36)$ \\
$\mathrm{N}$ & 24 & 41 & 48 & 41 & 154 \\
\hline
\end{tabular}

$\mathrm{N}=$ Número de animais analisados;

( ) = Valores esperados sob equilibrio de Hardy-Weinberg.

Para testar a aderência ao equilíbrio de Hardy-Weinberg, as classes genotípicas foram agrupadas em: Homozigotos para o alelo 5; Heterozigotos para o alelo 5; Homozigotos e heterozigotos para os demais alelos. Os resultados dessa análise são apresentados na Tabela 31. 
Tabela 31: Teste de aderência às proporções de equilíbrio de Hardy-Weinberg para o marcador INRA006

\begin{tabular}{cccccc}
\hline & \multicolumn{5}{c}{ Classes } \\
Genótipos $^{\mathrm{a}}$ & $\mathrm{G}_{3}$ & $\mathrm{G}_{4}$ & $\mathrm{G}_{5}$ & $\mathrm{G}_{6}$ & Total \\
\hline 55 & $2(4,59)$ & $6(5,49)$ & $5(7,13)$ & $8(8,35)$ & $21(25,37)$ \\
$5 \mathrm{x}$ & $17(11,81)$ & $18(19,02)$ & $27(22,74)$ & $21(20,30)$ & $83(74,27)$ \\
$\mathrm{xx}$ & $5(7,59)$ & $17(16,49)$ & $16(18,13)$ & $12(12,35)$ & $50(54,37)$ \\
\hline $\mathrm{N}$ & 24 & 41 & 48 & 41 & 154 \\
\hline$\chi^{2}{ }_{1 \mathrm{GL}}$ & $3,39^{\mathrm{b}}$ & 0,119 & 1,685 & 0,048 & 2,128 \\
\hline
\end{tabular}

${ }^{a}$ Os alelos menos frequentes foram agrupados. $\mathrm{x}=$ todos os alelos diferentes de 5 .

${ }^{b}$ Valor obtido aplicando-se correção de Yates.

( ) Valores esperados sob equilíbrio de Hardy-Weinberg.

$O$ valor de $\chi^{2}$ obtido para a classe $G_{3}$ foi de 4,629, o que implicaria na rejeição da hipótese de equilíbrio ao nível de $5 \%$ de probabilidade. Entretanto, nessa classe, o número observado de animais homozigotos para o alelo 5 foi reduzido e, em função do tamanho da amostra dessa classe, o teste de $\chi^{2}$ não é adequado. Com a finalidade de verificar a consistência do primeiro resultado, aplicou-se a correção para continuidade de Yates. $\mathrm{O}$ valor de $\chi^{2}$ obtido após correção não foi significativo e, em função do exposto, optou-se pela aceitação da hipótese de equilíbrio. Essa decisão foi reforçada pela probabilidade obtida pelo teste exato $(\mathrm{P}=0,091)$.

Considerados em conjunto, os resultados das análises para o marcador INRA006 foram consistentes com a hipótese de neutralidade fenotípica com relação ao rebanho da raça Canchim. Estudos conduzidos pela Universidade Texas A \& M identificaram uma associação entre esse marcador e o peso ao nascimento em cruzamentos de animais das raças Angus e Brahman (Davis \& Taylor, 1995). No presente estudo, nenhuma indicação de seleção sobre esse marcador foi observada. Esses resultados são coerentes quando consideramos que o rebanho Canchim foi selecionado no início de sua formação para peso à desmama, e desde o 
final dos anos 70 vem sendo selecionado para peso aos 12 meses. Estudos anteriores sobre a mudança genética dos pesos do período do nascimento até a desmama nesse rebanho indicaram que a mudança não foi significativa (Packer, 1977).

$\mathrm{Na}$ raça Charolesa, apenas três alelos foram observados para esse marcador, correspondentes aos alelos 1, 2 e 5 observados em Canchim. A distribuição dos genótipos na raça Charolesa e as frequências gênicas estimadas são apresentadas na Tabela 32 . $O$ valor de $\chi^{2}$ obtido para o teste de aderência das proporções genotípicas ao equilíbrio de HardyWeinberg não foi significativo demonstrando que, também na raça Charolesa, esse polimorfismo não foi afetado pela seleção, mutação ou deriva.

Tabela 32. Distribuição dos genótipos, frequências gênicas e valor de $\chi^{2}$ para o teste de aderência ao equilíbrio de HW para o marcador INRA006 na raça Charolesa.

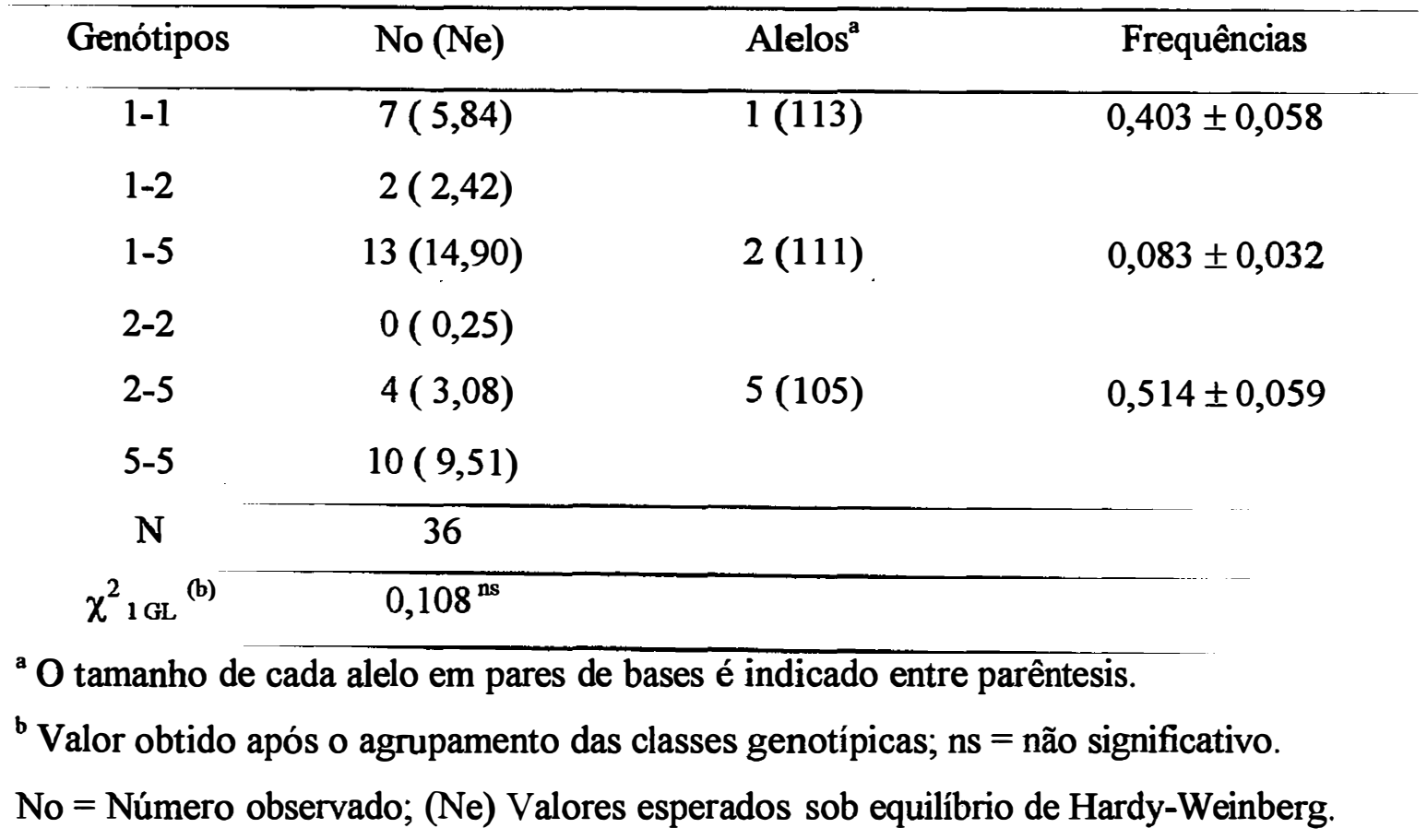




\subsection{Medidas de variabilidade}

Uma das consequências da manutenção de uma raça sintética como população fechada é a perda de variabilidade genética. Essa perda é inversamente proporcional ao tamanho efetivo da população base e diretamente proporcional à intensidade de seleção. As causas mais frequentes de perda de variabilidade são a deriva e a endogamia. Com a finalidade de analisar o comportamento da variabilidade genética ao longo do tempo, os valores de diversidade gênica e heterozigosidade foram calculados para cada loco, em cada geração. Esses parâmetros foram também estimados para a amostra da raça Charolesa. Os resultados dessas estimativas são apresentados na Tabela 33. Os valores de diversidade (D) e heterozigosidade $(\mathrm{H})$ para cada loco apresentaram grande variação. Na raça Canchim, os maiores valores de $\mathbf{H}$ foram observados para os marcadores INRA006 e CSFM50 e os menores valores para o marcador GH. Essa variação não foi tão acentuada na raça Charolesa, tendo-se obtido menores desvios-padrões das estimativas das médias de $\mathrm{D}$ e $\mathrm{H}$.

Apesar da raça Canchim ser uma raça sintética, na qual a heterozigosidade seria teoricamente maior do que em uma raça pura, os valores de heterozigosidade média foram inferiores aos estimados para a raça Charolesa. Esse fato pode ser decorrente da baixa heterozigosidade observada no loco $\mathrm{GH}$. A única exceção foi a classe $G_{6}$, que apresentou valores médios superiores aos da raça Charolesa. Nessa classe, a heterozigosidade para o loco GH foi 1,45 vezes superior à da classe $G_{3}$ e quase 6 vezes superior à da classe $G_{5}$. Para verificar essa hipótese, as médias de diversidade e heterozigosidade foram calculadas com base nos seis locos, excluindo-se o loco GH (Tabela 33). 


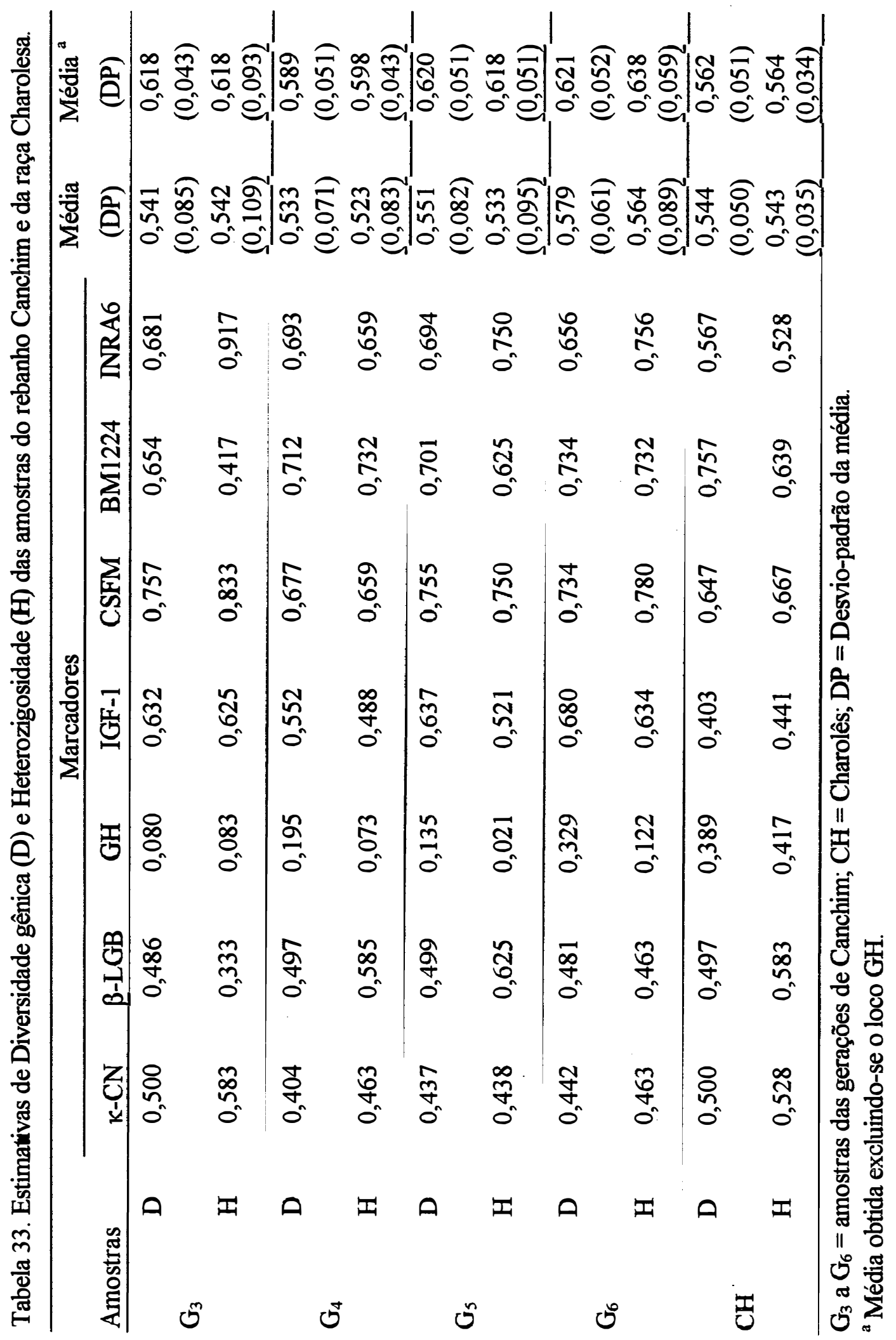


Os valores médios obtidos nessa análise foram superiores na raça Canchim. Além disso, os valores de desvio-padrão da média foram inferiores aos obtidos na análise anterior. Entretanto, a diferença entre as médias das raças Canchim e Charolesa foi menor do que se esperava em função da natureza dos dois materiais genéticos. Del Lama (1991) obteve estimativas de heterozigosidade média, com base em marcadores bioquímicos e imunológicos, para animais de diversos rebanhos e raças. A raça Charolesa apresentou o menor valor de $\mathrm{H}$, quando comparada à raças zebuínas e raças sintéticas, entre as quais a raça Canchim. Porém, naquele estudo, dois locos que apresentam polimorfismo exclusivamente em zebuínos foram incluídos nas comparações. No presente estudo, todos os locos foram polimórficos nas duas raças. Os resultados de variabilidade genética obtidos para a raça Charolesa estão de acordo com os relatados por Machugh et al (1994) que, utilizando marcadores de DNA microssatélite, observaram maiores índices de variabilidade para as raças Charolesa e Simmental quando comparadas às raças Aberdeen Angus, Hereford e Jersey... Outra consideração que deve ser feita na comparação entre as médias de $\mathbf{H}$ e $\mathbf{D}$ das raças Canchim $\mathbf{e}$ Charolesa é que a amostra desta última foi constituída por touros provenientes de diversos países (França, Canadá, Argentina e Brasil) e portanto representam diferentes "linhagens". Os animais utilizados na formação do Canchim eram todos provenientes da França. Dessa forma, é possivel que a base genética desses animais fosse menor do que a da amostra estudada.

A diferença entre as estimativas de heterozigosidade e diversidade para o marcador GH foram acentuadas nas classes $G_{4} a_{6}$. Essa discrepância pode ser atribuída ao intenso afastamento das proporções genotípicas observadas com relação ao equilibrio de HardyWeinberg, em consequência de um excesso de homozigotos. As estimativas desses dois parâmetros devem apresentar valores semelhantes quando o acasalamento é aleatório. Esse fato foi observado nas estimativas das médias de D e $\mathbf{H}$ para os sete locos na raça Charolesa, na qual a condição de equilíbrio foi observada para todos os marcadores.

A variação das médias de heterozigosidade e diversidade entre as amostras de Canchim foi pequena, sendo a máxima diferença entre as classes $\mathrm{G}_{6}$ e $\mathrm{G}_{4}$ da ordem de $4 \%$. Observa-se, portanto, que a perda de variabilidade para esses marcadores não foi evidenciada. Ao contrário, os maiores valores médios foram observados na classe $G_{6}$. $O$ aumento de 
variabilidade nessa classe pode ser resultante do aumento de frequência do alelo $\mathrm{V}$ de hormônio de crescimento e do alelo 4 de IGF-1, promovendo um maior equilibrio entre as frequências dos diferentes alelos nesses locos. Além disso, essa classe foi constituída em sua maioria por animais jovens, que não passaram por nenhum ciclo de seleção. A ausência de redução da variabilidade genética é consistente se considerarmos que aproximadamente $20 \%$ das fềmeas foram descartadas por ano, e que os acasalamentos foram realizados de modo a evitar a endogamia. O aumento da variabilidade foi observado por Ibrahim \& Larsen $\left(1966^{8}\right)$, citado por Rendel (1967), em animais da raça Red Danish. Nesse estudo, o grau médio de homozigosidade das fềmeas para o sistema B de antígenos eritrocitários foi de $14 \%$ nos anos 50 e de $12 \%$ nos anos 60 . Em machos, a média do parâmetro não sofreu alteração.

Efeitos negativos da geração sobre características de produção de fêmeas desse rebanho da raça Canchim, provavelmente resultantes da presença de menor heterose residual nas fềmeas de gerações mais avançadas, foram verificados por Barbosa (1991). Os mecanismos genéticos envolvidos na heterose ainda são alvo de controvérsia. Entre esses mecanismos, a dominância é considerada como responsável por parte dos efeitos, mascarando a expressão de genes deletérios. A atribuição da heterose ao efeito de sobredominância é mais controvertido. Nesse caso, os indivíduos heterozigotos para um determinado loco apresentam um maior valor fenotípico do que ambos os homozigotos. Esse efeito seria provavelmente resultante da interação entre os produtos gênicos codificados pelos diferentes alelos do loco em questão. A existência de correlação entre heterozigosidade e heterose tem sido verificada em muitos estudos conduzidos em animais e plantas (Mitton \& Pierce, 1980). Os resultados obtidos no presente trabalho não revelaram uma tendência de perda de heterozigosidade entre as gerações 3 e 6 . É importante salientar que as estimativas de $\mathrm{H}$ e $\mathrm{D}$ foram obtidas com base em sete marcadores, localizados em diferentes cromossomos. Dessa forma, apenas 7 dos 30 cromossomos dos bovinos foram representados. Outro fato que deve ser ressaltado é que os animais analisados por Barbosa (1991) pertenciam a gerações menos avançadas desse rebanho (gerações 1 a 3), nas quais a heterose residual e a heterose materna devem desempenhar um papel mais importante do que em gerações mais avançadas. De fato, as maiores diferenças de

\footnotetext{
${ }^{8}$ IBRAHIM, I.I. \& LARSEN, B.Allele frequencies in the blood system in Red Danish cattle. Arsberetn.Inst.Sterilitetsforsk.K.Vet.- og Landbohojsk., 57-64, 1966.
} 
média para os pesos à desmama e aos 365 dias observadas por aquele autor ocorreram entre a primeira geração e as gerações subsequentes. Considerando que parte da heterose seja resultante de efeitos de dominância, a medida que a carga genética da população sintética é eliminada pela seleção, o efeito de mascaramento de genes deletérios perde sua importância relativa

\subsection{Estatística F}

Com a finalidade de descrever a estrutura da população Canchim, os coeficientes de fixação de Wright foram estimados pelo programa de computador Biosys 1 (Swofford \& Selander, 1989). Os valores médios obtidos para cada loco são apresentados na Tabela 34.

Os índices de fixação $F_{\mathrm{IS}}$ e $\mathrm{F}_{\mathrm{IT}}$ fornecem uma estimativa da correlação entre dois gametas de uma subpopulação e da população como um todo, respectivamente. Os valores médios de $\mathrm{F}_{\mathrm{IS}}$ por loco variaram de -0,131 para o marcador INRA006 a 0,595 para o loco GH. Entretanto, apenas os valores de $F_{\text {IS }}$ e $F_{\text {IT }}$ obtidos para o loco GH foram significativos. Esses resultados reforçam a hipótese de existência de seleção ou de acasalamento preferencial em relação ao polimorfismo do gene do hormônio de crescimento. Os valores dos coeficientes de fixação para esse loco foram muito superiores aos observados para os demais locos, indicando que a endogamia não deve ser considerada como a única causa do excesso de homozigotos para esse marcador. Uma possível causa para esse excesso de homozigotos seria o efeito de amostragem. Uma vez que as amostras foram obtidas dentro de gerações, a correlação entre os gametas poderia ter sido aumentada pelo efeito de touro, uma vez que animais de geração 3 são filhos de touros de geração 2 e assim sucessivamente. Porém, da mesma forma que o efeito de endogamia, o efeito de amostragem deveria ter sido observado em todos os locos.

A média das estimativas de $F_{I S}(0,020)$ foi superior à média de endogamia da população, calculada pelo pedigni (Tabela 35). $O$ coeficiente $F_{I S}$ fornece uma estimativa da correlação entre dois gametas de uma subpopulação. Essa correlação é função não apenas do grau de endogamia dos indivíduos, como também do grau de parentesco entre os indivíduos 
dentro de subpopulações, neste trabalho representadas por gerações. Além disso, para o cálculo de endogamia pelo pedigri, as informações dos ancestrais dos animais fundadores (5/8 Charoles, 3/8 Zebu) não foram incluídas na análise. Dessa forma, os valores apresentados na Tabela 35 podem ser uma subestimativa da endogamia.

Tabela 34. Coeficientes de Fixação Médios por marcador, médias entre marcadores e teste de $\chi^{2}$ de significância.

\begin{tabular}{lccccccccc}
\hline Loco & $\mathrm{F}_{\mathrm{IS}}$ & $\chi^{2}$ & $\mathrm{GL}$ & $\mathrm{F}_{\mathrm{IT}}$ & $\chi^{2}$ & $\mathrm{GL}$ & $\mathrm{F}_{\mathrm{ST}}$ & $\chi^{2}$ & $\mathrm{GL}$ \\
\hline K-CSN & $-0,093$ & $0,33^{\text {ns }}$ & 1 & $-0,059$ & $0,13^{\text {ns }}$ & 1 & 0,031 & $6,93^{\text {ns }}$ & 3 \\
B-LGB & $-0,022$ & $0,02^{\text {ns }}$ & 1 & $-0,018$ & $0,01^{\text {ns }}$ & 1 & 0,004 & $1,32^{\text {ns }}$ & 3 \\
GH & 0,595 & $13,63^{* *}$ & 1 & 0,611 & $14,37^{* *}$ & 1 & 0,040 & $11,21^{*}$ & 3 \\
MS-IGF-I & 0,093 & $1,00^{\text {ns }}$ & 6 & 0,113 & $1,47^{\text {ns }}$ & 6 & 0,022 & $17,00^{*}$ & 9 \\
CSFM50 & $-0,034$ & $0,22^{\text {ns }}$ & 15 & $-0,015$ & $0,04^{\text {ns }}$ & 15 & 0,018 & $19,1^{\text {ns }}$ & 15 \\
BM1224 & 0,106 & $2,16^{\text {ns }}$ & 15 & 0,117 & $2,64^{\text {ns }}$ & 15 & 0,012 & $9,81^{\text {ns }}$ & $9^{\mathrm{a}}$ \\
INRA006 & $-0,131$ & $3,96^{\text {ns }}$ & 21 & $-0,124$ & $3,55^{\text {ns }}$ & 21 & 0,006 & $3,58^{\text {ns }}$ & $6^{\mathrm{a}}$ \\
\hline Média & 0,020 & & & 0,036 & & & 0,016 & $68,95^{*}$ & 48 \\
\hline
\end{tabular}

ns = não significativo; * Significativo a 5\%; ** Significativo a $1 \%$.

${ }^{a}$ Valores obtidos agrupando os alelos menos frequentes.

Li \& Horwitz (1953) sugerem que apenas marcadores neutros sejam utilizados para a estimativa do valor de F, quando se tem por objetivo descrever a endogamia de uma população. Nesse caso, o coeficiente de fixação não é afetado por efeitos de seleção e fornece uma estimativa mais precisa do efeito de endogamia. No presente estudo, o loco GH apresentou indicações de acasalamento preferencial e de um favorecimento do alelo $\mathbf{V}$ ao longo das gerações. 
Tabela 35. Distribuição dos coeficientes de endogamia $(f)$ calculados pelo pedigri nas quatro gerações de Canchim.

\begin{tabular}{ccccc}
\hline Classe & $\mathrm{N}$ & Média $\pm \mathrm{EP}$ & Mínimo & Máximo \\
\hline $\mathrm{G}_{3}$ & 24 & 0 & 0 & 0 \\
$\mathrm{G}_{4}$ & 41 & $0,002 \pm 0,007$ & 0 & 0,031 \\
$\mathrm{G}_{5}$ & 48 & $0,014 \pm 0,026$ & 0 & 0,125 \\
$\mathrm{G}_{6}$ & 41 & $0,014 \pm 0,015$ & 0 & 0,074 \\
\hline Total & 154 & $0,008 \pm 0,018$ & 0 & 0,125 \\
\hline
\end{tabular}

Para testar a significância dos valores médios de $F_{S T}$ por loco (Tabela 34), o valor de $\chi^{2}$ para tabelas de contingência do total de cada alelo nas quatro gerações foi utilizado. Nos locos com dois alelos, esse teste equivale ao teste de independência apresentado anteriormente. Nos locos com mais de dois alelos, o teste de independência de um alelo contra os demais seria equivalente ao teste de significância de $\mathrm{F}_{\mathrm{ST}}$ para aquele alelo. Para avaliar a significância da média de $\mathrm{F}_{\mathrm{ST}}$ nesses locos, as tabelas de contingência foram montadas com todos os alelos observados, simultaneamente. Nos locos BM1224 e INRA006, os alelos menos frequentes foram agrupados de forma a atender a condição de que nenhuma célula da tabela de contingência apresentasse valores esperados menores do que 1 . Os valores médios de $F_{S T}$ dos locos GH e IGF-I foram significativos (Tabela 34), reforçando os resultados anteriores de divergência das gerações com relação a esses marcadores. $O$ mesmo fato não foi observado com relação ao marcador CSFM50. Nesse loco, a frequência de apenas um, entre os seis alelos observados, variou significativamente entre as gerações. A média de $F_{S T}$ entre locos foi 
testada pela soma dos valores de $\chi^{2}$ obtidos para a média de cada loco (Vencovsky, $1996^{9}$ ). Apesar da ausência de significância do valor médio de $\mathrm{F}_{\mathrm{ST}}$ em cinco dos sete marcadores analisados, quando as informações dos sete locos foram consideradas em conjunto, concluiu-se que a divergência entre as gerações foi significativa (Tabela 34).

\subsection{Distâncias Genéticas}

Com a finalidade de identificar as relações entre as gerações de Canchim, a raça Charolesa e raças zebuínas, as distâncias Euclidiana Média (DEM) e distância de Nei (1978) foram calculadas. As frequências gênicas dos marcadores $\kappa$-caseína e $\beta$-lactoglobulina na raça Gir foram extraídas da literatura (Kemenes, 1996). Para a raça Guzerá, e para o loco GH em todas as raças zebuínas, dados não publicados do Laboratório de Biotecnologia Animal (ESALQ - USP) foram utilizados. A única raça zebuina para a qual as frequências gênicas dos sete marcadores estudados eram disponíveis foi a raça Nelore (Rosa, $1996^{10}$ ).

As distâncias Euclidianas Médias entre as gerações de Canchim e as raças Charolesa e Nelore, considerando os sete marcadores, são apresentadas na Tabela 36. A maior distância foi observada entre as raças Charolesa e Nelore, de acordo com o esperado em função da origem distinta dessas populações. As distâncias entre as gerações de Canchim não seguiram um padrão linear, tendo sido a maior distância observada entre as gerações $\mathrm{G}_{3}$ e $\mathrm{G}_{4}$ seguida da distância entre $\mathrm{G}_{3}$ e $\mathrm{G}_{6}$. Esse comportamento reflete as oscilações de frequências gênicas entre as gerações, verificadas na maioria dos marcadores estudados. Da mesma forma, as distâncias das quatro gerações de Canchim com relação às raças Charolesa e Nelore sofreram oscilações. As relações entre os diferentes grupos genéticos são melhor visualizadas no dendrograma, construído a partir da análise de agrupamento pelo método UPGMA (Figura 13).

\footnotetext{
${ }^{9}$ Vencovsky, R. Departamento de Genética. Escola Superior de Agricultura "Luiz de Queiroz"- USP. Piracicaba, SP. Comunicação pessoal, 1996.

${ }^{10}$ Rosa, A.J.M. Laboratório de Biotecnologia Animal, Departamento de Zootecnia. Escola Superior de Agricultura "Luiz de Queiroz"- USP. Piracicaba, SP. Comunicação pessoal, 1996.
} 
Tabela 36. Distâncias Euclidianas Médias para os sete marcadores.

\begin{tabular}{|l|llllll|}
\hline População & CN3 & CN4 & CN5 & CN6 & CH & NE \\
\hdashline CN3 & - & & & & & \\
CN4 & 0,084 & - & & & & \\
CN5 & 0,071 & 0,053 & - & & & \\
CN6 & 0,083 & 0,061 & 0,054 & - & & \\
CH & 0,147 & 0,165 & 0,163 & 0,150 & - & \\
NE & 0,207 & 0,211 & 0,203 & 0,202 & 0,250 & - \\
\hline
\end{tabular}

$\mathrm{CN} 3, \mathrm{CN} 4, \mathrm{CN} 5$ e CN6 = Gerações $\mathrm{G}_{3}$ a $\mathrm{G}_{6}$ de Canchim ; $\mathrm{CH}=$ Charolês; $\mathrm{NE}=$ Nelore.

Na Figura 13, observa-se que a maior diferenciação entre as gerações de Canchim foi entre a classe $\mathrm{G}_{3} \mathrm{e}$ as demais. Essa diferenciação pode ter sido decorrente do pequeno número de animais analisados nessa classe e da natureza da amostra, constituída por todos os animais de geração inferior a 3,51 que permaneceram no rebanho. O agnupamento das quatro gerações de Canchim com a raça Charolesa foi consistente com a composição genética da primeira (5/8 Charolês, 3/8 Zebu). A correlação cofenética obtida na análise de agrupamento indica que houve uma alta concordância entre os dados da matriz de distância genética e os agrupamentos do dendrograma. 


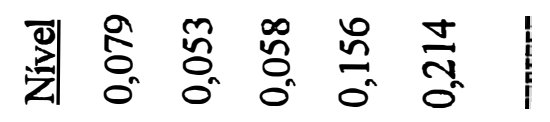

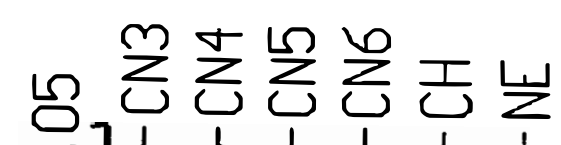

0
0
0
0
0
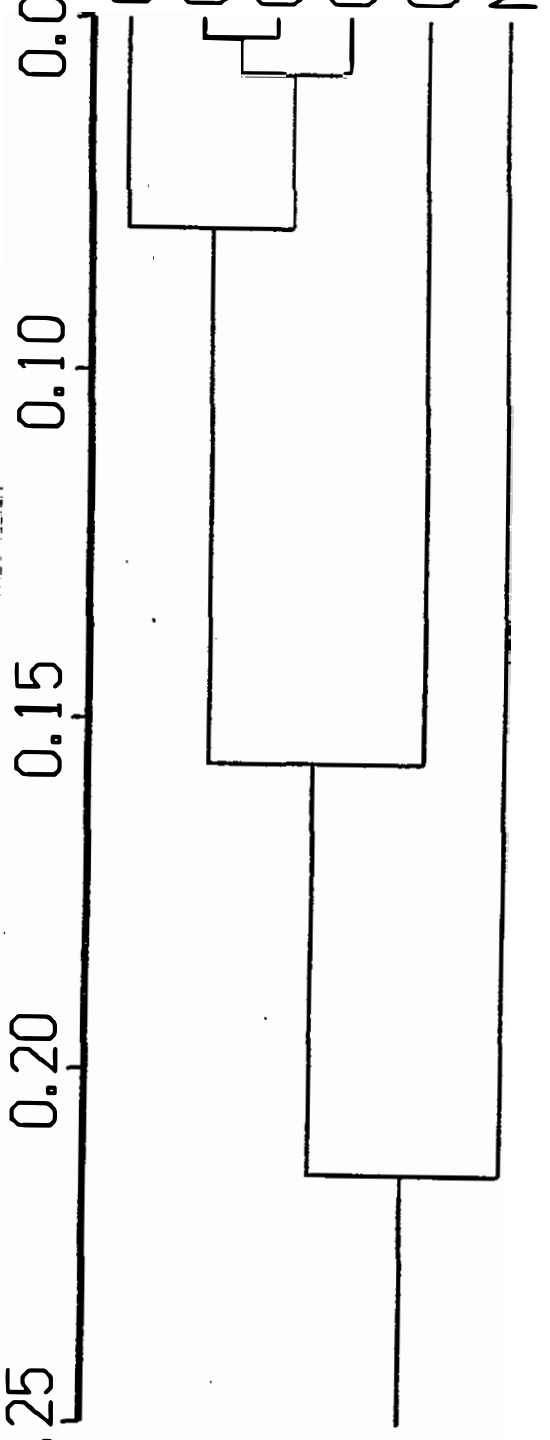

๑

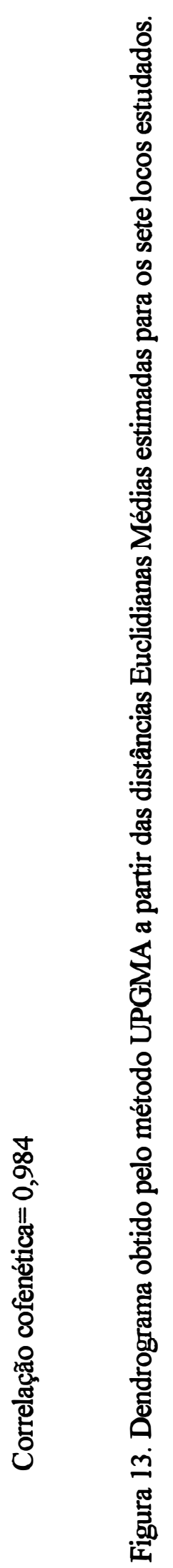


Os valores de distância genética de Nei (1978) são apresentados na Tabela 37. Também nessa análise a maior distância foi observada entre as raças Charolesa e Nelore, que pertencem às espécies Bos taurus e Bos indicus, respectivamente. Os valores de distância entre as gerações de Canchim foram inferiores aos obtidos para a distância Euclidiana Média. Esse comportamento era esperado, uma vez que a distância de Nei é mais apropriada para a divergência a longo prazo com relação a uma população ancestral. Nesses casos, essa medida fornece uma estimativa do tempo transcorrido no processo de divergência (Nei, 1987). Entretanto, os resultados da análise de agnupamento (Figura 14) foram semelhantes aos obtidos a partir da DEM.

Tabela 37. Distância de Nei (1978) considerando os sete marcadores.

\begin{tabular}{|c|c|c|c|c|c|c|}
\hline & CN3 & $\mathrm{CN} 4$ & CN5 & CN6 & $\overline{\mathrm{CH}}$ & $\overline{\mathrm{NE}}$ \\
\hline $\mathrm{CN} 3$ & 0 & & & & & \\
\hline CN4 & 0,052 & 0 & & & & \\
\hline CN5 & 0,04 & 0,023 & 0 & & & \\
\hline CN6 & 0,051 & 0,029 & 0,025 & 0 & & \\
\hline $\mathrm{CH}$ & 0,140 & 0,172 & 0,170 & 0,148 & 0 & \\
\hline NE & 0,254 & 0,260 & 0,242 & 0,243 & 0,390 & 0 \\
\hline
\end{tabular}

CN3, CN4, CN5 e CN6 = Gerações $\mathrm{G}_{3}$ a $_{6}$ de Canchim ; $\mathrm{CH}=$ Charolês; $\mathrm{NE}=$ Nelore. 


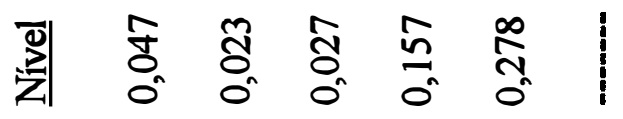

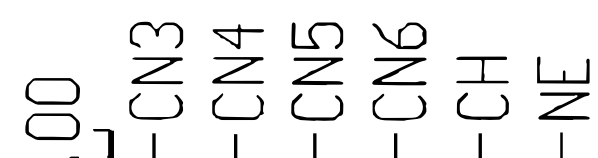

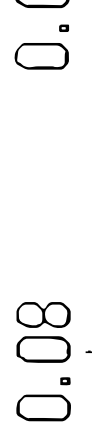

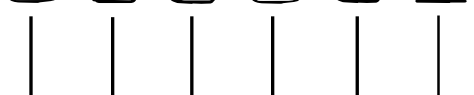

을

兽

ᄋ్ర

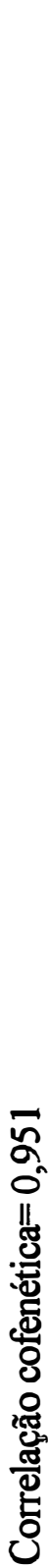

ฮั

ฉ

홇

๙ิ

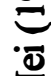

잉

뜔

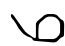

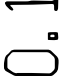

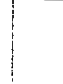

$\oslash_{0}^{\square}$

$m$

$\varnothing$

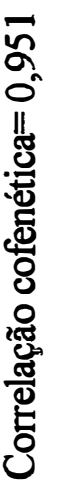

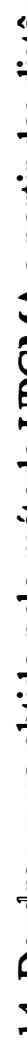

흄

范

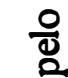

을 
Os valores médios de distância entre os grupos foram elevados. A média da distância entre o gnupo formado pelas gerações 4,5 e 6 e a geração 3 foi de 0,047. Esse valor corresponderia à distância entre raças (Nei, 1987). Da mesma forma, a distância entre as gerações de Canchim e a raça Charolesa $(0,157)$ foi superior à estimada por Del Lama $(1991)$ entre as raças Charolesa e Canchim $(0,018)$. Os altos valores de distância estimados no presente trabalho podem ser atribuídos aos seguintes fatores: As estimativas de distância de Nei pressupõem que a divergência entre as populações é um processo constante para todos os locos. Nesse caso, a presença de seleção não altera as estimativas desde que ocorra com a mesma intensidade em todos os locos (Nei, 1987). No presente estudo, a divergência não apresentou um padrão constante, de acordo com as análises de variação das frequências gênicas. Um segundo fator está relacionado às estimativas de heterozigosidade. De acordo com Nei (1978), a análise de um grande número de marcadores ou de indivíduos é ainda mais importante quando as populações comparadas apresentam heterozigosidade maior do que 0,1. As estimativas de distância entre raças, sub-espécies e espécies apresentadas por Nei (1987) foram extraídas de estudos que utilizaram mais de 20 marcadores.

Com a finalidade de avaliar as relações entre as gerações de Canchim e as raças que contribuíram para a sua formação, os dados de $\kappa$-caseína, $\beta$-lactoglobulina e hormônio de crescimento das raças Nelore, Guzerá e Gir foram utilizados para calcular as distâncias Euclidianas Médias (Tabela 38). As distâncias observadas entre as raças zebuínas foram inferiores às observadas entre as gerações de Canchim. Esse fato pode ser atribuído à variação significativa de frequências gênicas ao longo das gerações de Canchim em três dos sete locos analisados. Além disso, nas raças zebuínas o loco GH se mostrou monomórfico, e portanto, não contribuiu para a diferenciação entre os membros desse grupo (Figura 15). A maior semelhança entre as raças zebuínas foi observada entre as raças Gir e Guzerá. Esse resultado está de acordo com os obtidos por Del Lama (1991), utilizando polimorfismos bioquímicos e imunológicos. Entretanto, os valores de distância entre a raça Guzerá e as gerações de Canchim não eram esperados (Tabela 38). Entre as raças zebuínas utilizadas para a formação do Canchim, a maior contribuição foi da raça Indubrasil, seguida pela raça Guzerá e por uma participação relativamente pequena da raça Nelore. A raça Indubrasil foi classificada por Del Lama (1991) como mais próxima das raças Gir e Guzerá. Esses resultados sugerem que as 
comparações entre as gerações de Canchim e as raças que participaram da sua formação devem levar em consideração que as populações atuais dessas últimas não representam a população utilizada na formação do Canchim. A correlação cofenética entre os dados da matriz de distância e os agrupamentos representados na Figura 14 foi a menor entre todas as análises de agrupamentos realizadas nesse trabalho. De acordo com Bussab et al. (1990), um valor de correlação em torno de 0,8 pode ser considerado como indicativo de um bom ajuste da análise de agrupamentos. Dessa forma, as informações referentes a apenas três marcadores não devem ser generalizadas para definir as relações genéticas entre as populações mas fornecem uma idéia razoável dos agnupamentos.

Tabela 38. Distâncias Euclidianas Médias considerando os três marcadores de RFLP.

\begin{tabular}{|l|llllllll|}
\hline & CN3 & CN4 & CN5 & CN6 & CH & NE & GU & GIR \\
\hdashline CN3 & 0 & & & & & & & \\
CN4 & 0,136 & 0 & & & & & & \\
CN5 & 0,110 & 0,034 & 0 & & & & & \\
CN6 & 0,137 & 0,072 & 0,089 & 0 & & & & \\
CH & 0,147 & 0,155 & 0,149 & 0,126 & 0 & & & \\
NE & 0,240 & 0,133 & 0,149 & 0,184 & 0,287 & 0 & & \\
GU & 0,253 & 0,152 & 0,170 & 0,195 & 0,306 & 0,033 & 0 & \\
GIR & 0,251 & 0,147 & 0,165 & 0,192 & 0,301 & 0,022 & 0,011 & 0 \\
\hline
\end{tabular}

$\mathrm{CN} 3, \mathrm{CN} 4, \mathrm{CN} 5$ e CN6 = Gerações $\mathrm{G}_{3}$ a $\mathrm{G}_{6}$ de Canchim ; $\mathrm{CH}=$ Charolês; $\mathrm{NE}=$ Nelore. 

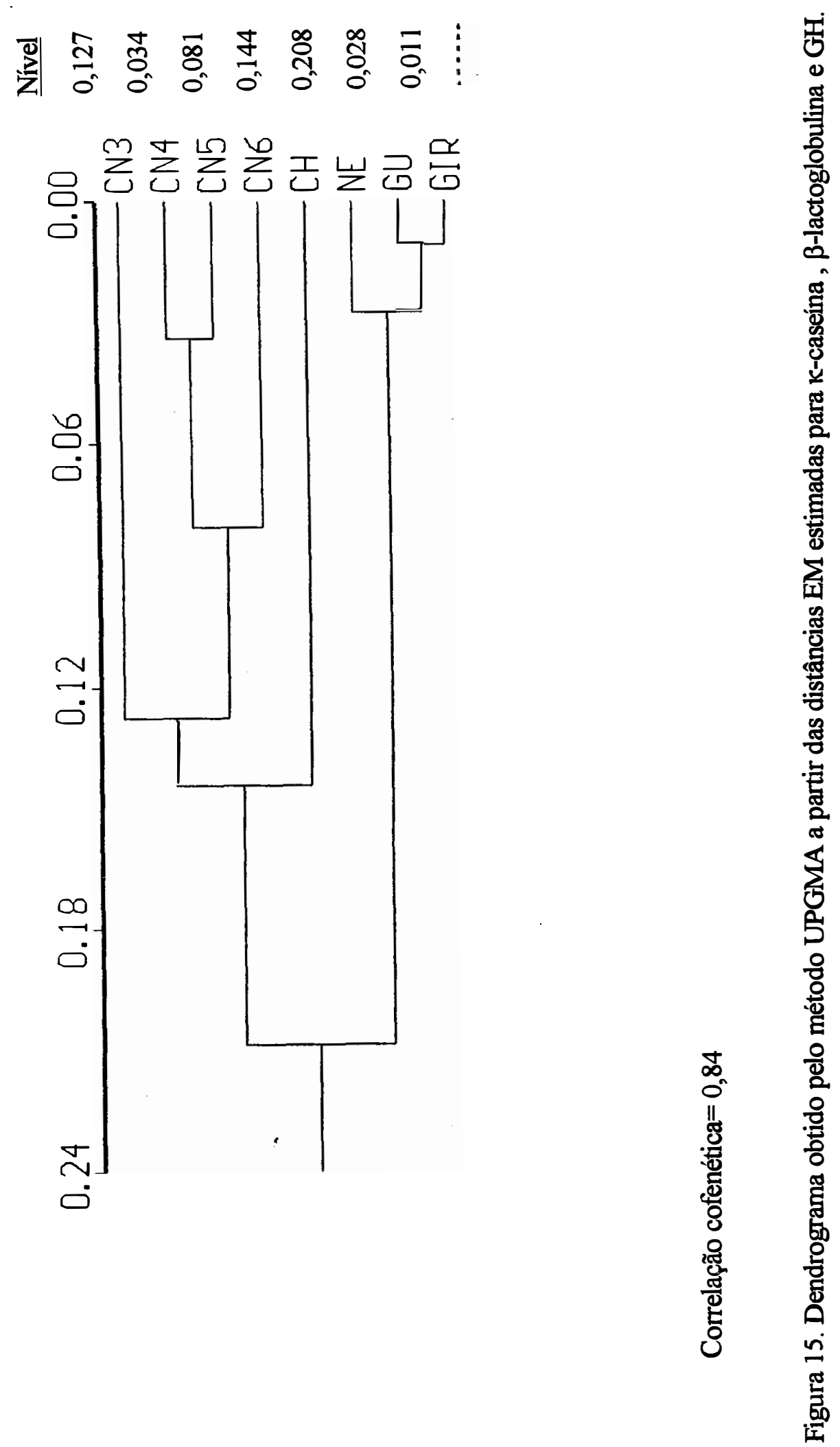


\subsection{Considerações finais}

A variação das frequências gênicas ao longo de quatro gerações do rebanho da raça Canchim foi significativa para o polimorfismo do gene de hormônio de crescimento, para o microssatélite da extremidade 5' do gene de IGF-I e para o microssatélite CSFM50, tendo sido não significativa para os demais marcadores.

A variação de frequência no loco $\mathrm{GH}$ foi consistente com a hipótese de seleção a favor do alelo $\mathrm{V}$, tendo apresentado um padrão linear de mudança de frequência gênica. Essa hipótese foi reforçada pelos desvios significativos das proporções genotípicas de equilíbrio de Hardy-Weinberg, resultantes do acúmulo de homozigotos. No microssatélite IGF-I o aumento de frequência do alelo 4 não foi linear, podendo ter sido resultante de deriva, seleção ou ambas. É interessante observar que os dados obtidos com raças zebuínas mantidas no Brasil revelaram a fixação do alelo $\mathrm{L}$ de hormônio de crescimento. Dessa forma, o alelo $\mathrm{V}$ representa um marcador da raça Charolesa na população Canchim. Da mesma forma, o alelo 4 do MSIGF-I não foi observado na raça Charolesa e foi predominante na raça Nelore, sendo portanto um marcador para raças zebuínas. Considerando a intensa relação fisiológica entre o hormônio de crescimento e o fator de crescimento IGF-I, os efeitos do aparecimento de novas combinações genotípicas para esses dois genes podem ser relevantes. $\mathbf{O}$ fenômeno da epistasia é frequentemente desconsiderado nas análises de caracteres quantitativos. A avaliação da contribuição de locos individuais baseada em marcadores genéticos deve ser uma estratégia eficiente para a determinação da magnitude dos efeitos de epistasia sobre caracteres de interesse econômico. Em função do número limitado de animais estudados no presente trabalho e da distribuição desses animais ao longo do tempo e em diferentes experimentos, nenhum estudo de associação com características de produção foi conduzido. Entretanto, as indicações obtidas justificam a realização de experiment adequado ao mapeamento de QTLs e à estimativa do efeito da substituição dos alelos desses marcadores sobre caracteństicas de produção e adaptação às condições tropicais. Outra abordagem para essa questão seria a investigação do efeito do polimorfismo do microssatélite IGF-I na expressão desse gene e da relação fisiológica entre o polimorfismo do hormônio de 
crescimento e do microssatélite do gene IGF-I, de maneira a permitir uma maior compreensão dos resultados obtidos em Canchim.

O marcador CSFM50 está situado em uma região do cromossomo 2 dos bovinos que foi associada à diversas medidas de peso, desde a desmama até a maturidade, em cruzamentos entre as raças Angus e Brahman. A variação de frequência do alelo 8 desse loco foi significativa e linear ao longo das gerações de Canchim, sugerindo seleção contra os indivíduos que possuem esse alelo. Uma das preocupações com relação à aplicação do mapeamento de QTLs no melhoramento animal é a de que as associações de marcadores com características de importância econômica devem ser válidas apenas para a população em que foram determinados, principalmente quando a associação for resultante de desequilíbrio de ligação e não de um efeito direto do marcador. Além disso, considerando que em diferentes ambientes, a variação de uma característica quantitativa pode ser decorrente da expressão de genes diferentes, seria admissível que as associações à QTLs obtidas em um determinado ambiente fossem pouco úteis para ambientes diversos. Os resultados obtidos para o microssatélite CSFM50 sugerem que, em alguns casos, essas associações podem ser válidas para diferentes populações e ambientes. Sendo assim, o estudo de marcadores previamente associados com características de produção pode representar uma redução no tempo dispendido para a identificação de QTLs.

Embora quatro dos sete locos analisados, quando considerados individualmente, não tenham apresentado variação significativa, na análise conjunta de todos os locos obteve-se uma diferenciação significativa entre as gerações $(P>0,05)$. Estudos anteriores sobre o ganho genético nesse rebanho, utilizando métodos de genética quantitativa, haviam demonstrado que praticamente não houve mudança genética para características de ganho de peso, nos períodos avaliados. As alterações de frequência observadas no presente trabalho sugerem que a avaliação de locos individuais apresenta uma maior sensibilidade para detectar alterações genéticas.

As medidas de heterozigosidade e diversidade gênica não indicaram uma tendência de perda de variabilidade para os locos analisados. Ao contrário, a média de heterozigosidade estimada para a última geração foi superior ou igual às médias estimadas para as primeiras gerações analisadas. Esse resultado era esperado em função da prevenção de acasalamentos 
endogâmicos que é praticada no programa de melhoramento dessa população. $\mathbf{O}$ aumento da variabilidade genética reflete também as mudanças de frequências gênicas que ocorreram na população, promovendo um maior equilíbrio em alguns locos que apresentavam alelos com frequências extremas nas gerações menos avançadas. Esse aumento de variabilidade está relacionado, portanto, ao momento em que esse processo de mudança foi observado. A persistência das tendências de aumento ou redução das frequências discutidas para os marcadores GH, MS-IGF-I e CSFM50 deve resultar, ao longo do tempo, em redução da variabilidade genética. 


\section{CONCLUSÕES}

- A variação das frequências gênicas ao longo das gerações de Canchim foi significativa para o polimorfismo do gene do hormônio de crescimento, para o microssatélite da extremidade 5 'do gene do fator de crescimento semelhante à insulina do tipo I e para o microssatélite CSFM50. Nos demais marcadores, a variação não foi significativa;

- A variação de frequência no loco GH foi consistente com a hipótese de seleção a favor do alelo V;

- No microssatélite do gene IGF-I, o aumento de frequência do alelo 4 não foi linear, podendo ter sido resultante de deriva, seleção ou ambas;

- As variações de frequência observadas nos locos GH e IGF-I sugerem que na seleção para desenvolvimento ponderal dessa raça sintética, em condições tropicais, tanto genes de tauninos quanto de zebuínos foram favorecidos;

- Apesar da variação de frequência do alelo 8 do loco CSFM50 ter sido significativa e apresentado um padrão linear, a condição de equilíbrio de Hardy-Weinberg observada em todas as gerações não foi consistente com a hipótese de acasalamento preferencial;

- Os resultados de avaliação da variabilidade genética demonstraram que, apesar de se tratar de um rebanho fechado, não houve perda de variabilidade ao longo das gerações estudadas;

- Embora a metodologia empregada no presente trabalho não permita identificar e quantificar os efeitos associados aos marcadores, a análise do comportamento das frequências gênicas ao longo das gerações de uma população sintética forneceu indicações de genes candidatos 
a associação com características selecionadas nessa população. Esses resultados poderão ser utilizados para direcionar trabalhos futuros de mapeamento de QTLs;

- Os resultados das análises de distâncias genéticas foram coerentes com a história das raças analisadas, tanto nas análises que utilizaram as informações dos sete marcadores quanto na análise utilizando apenas marcadores do tipo I (genes). Apesar de um grande número de marcadores unilocais altamente polimórficos ter sido descrito no genoma dos bovinos, até recentemente, pouco uso tem sido feito dessa informação para o estudo de populações. Os resultados obtidos nas análises de distância desse trabalho demonstram que os polimorfismos de sequências simples podem ser informativos para a comparação entre populações. 


\section{REFERÊNCIAS BIBLIOGRÁFICAS}

ALENCAR, M.M. Bovino - raça Canchim: Origem e desenvolvimento. EMBRAPA - DDT, Brasilia, 1986. 102p.

ALENCAR, M. M. \& BARBOSA, P. F. Fertilidade de um rebanho Canchim criado em regime exclusivo de pasto. Revista da Sociedade Brasileira de Zootecnia, 10: 89-102, 1981.

ALENCAR, M.M.; SILVA, A.H.G. \& BARBOSA, P.F. Efeitos da consanguinidade sobre o peso à desmama de bezerros da raça Canchim. Revista da Sociedade Brasileira de Zootecnia, 10: 156 - 172, 1981.

BAKER, C.M.A. \& MANWELL, C. Population genetics, molecular markers and gene conservation of bovine breeds. In: HICKMAN, C.G.. Cattle genetics resources Amsterdan, Elsevier, 1991. p.221-304.

BARBOSA, P.F. Heterose, heterose residual e efeitos da recombinação em sistemas de cruzamento de bovinos. Série Monografias, 2. Revista da Sociedade Brasileira de Genética, 1995. p.135-243.

BARBOSA, P.F. Análise genético-quantitativa de características de crescimento e reprodução em fềmeas da raça Canchim. Ribeirão Preto, 1991. 237p. (Doutorado - Faculdade de Medicina de Ribeirão Preto, Universidade de São Paulo). 
BARENDSE, W.; ARMTTAGE, S. M.; KOSSAREK, L. M.; SHALOM, A; KIRKPATRICK, B. W.; RYAN, A. M.; CLAYTON, D.; LI, L.; NEIBERG, H. L.; ZHANG, N.; GROSSE, W.M.; WEISS, J.; CREIGHTON, P.; McCARTHY, F.; RON, M.; TEALE, A J.; FRIES, R; McGRAW, R. A.; MOORE, S. S.; GEORGES, M.; SOLLER, J. E; WOMACK, J. E.; HETZEL, D. J. S. A genetic linkage map of the bovine genome. Nature Genetics, 6: 227-244, 1994.

BARKER J.S.F.; EAST, P.D.; WEIR, B.S. Temporal and microgeographic variation in allozyme frequencies in a natural population of Drosophila buzzatti. Genetics, 112: 577-611, 1986.

BARLOW, R. Biological ramifications of selection for preweaning growth in cattle: a review. Animal Breeding Abstracts, 46: 469 - 494, 1978.

BAUMAN, D.E. \& VERNON, R.G. Effects of exogenous bovine somatotropin on lactation. Annual Review of Nutrition, 13: 437-461, 1993.

BECKMANN, J.S.; KASHI, Y; HALLERMAN, E.M.; NAVE, A; SOLLER, M. Restriction fragment length polymorphism among Israeli Holstein Friesian dairy bulls. Animal Genetics, 17: 25-38, 1986.

BELL, G.I.; SELBY, M.J. \& RUTTER, W.J. The highly polymorphic region near the human insulin gene is composed of simple tandemly repeating units. Nature, 295: 31, 1982.

BISHOP, M. D.; KAPPES, S. M.; KEELE, J. W.; STONE, R. T.; SUNDEN, S.L.F.; HAWKINS, G. A; TOLDO, S. S.; FRIES, R; GROSZ, M. D.; YOO, J.; BEATTIE, C. W. A genetic linkage map for cattle. Genetics, 136: 619-639, 1994.

BOLDMAN, K.G.; KRIESE, L.A; Van VLECK, L.D. A manual for use of MTDFREML. Lincoln: Agricultural Research Service, USDA, 1993. 120p. 
BOVENHUIS, H.; VAN ARENDONK, J.A.M.; KORVER, S. Association between milk protein polymorphisms and milk production traits. Journal of Dairy Science 75:2549-2559, 1992.

BOYD, R.D. \& BAUMAN, D.E. Mechanisms of action for somatotropin in growth. In: CAMPION, D. R; HAUSMAN, G. J.; MARTIN, R. J. (eds.) Animal Growth Regulation. Plenum Publishing Coorporation, 1989. cap. 12, p. 257-293.

BRADLEY, D.G.; Mac HUGH, D.E.; LOFTUS, R.T.; SOW, R.S.; HOSTE, C.H. CUNNINGHAM, E.P. Zebu-taurine variation in Y chromosomal DNA: a sensitive assay for genetic introgression in West African trypanotolerant cattle populations. Animal Genetics, 25: 7-12, 1994.

BRINKS, J.S.; CLARK, R.T. \& RICE, F.J. Estimation of genetic trends in beef cattle. Journal of Animal Science, 20: 903, 1961.

BRUFORD, M.W.; HANOTTE, O.; BROOKFIELD,J.F.Y.; BURKE, T. Single-locus and multilocus DNA fingerprinting. In: HOEZEL, A.R. (ed.). Molecular Genetic Analysis of Populations. A Practical Approach. IRL Press, Oxford, 1992. cap. 8, p. 225-269.

BUSSAB, W. O.; MIAZAKI, E. S.; ANDRADE, D. F. Introdução à Análise de Agrupamentos. In: Associação Brasileira de Estatística, $9^{\circ}$ Simpósio Nacional de Probabilidade e Estatística, São Paulo, Julho de 1990.

CEPICA, S.; WOLF, J.; HOJNY, J.; VACKOVA, I.; SCHROFFERL Jr., J. Relations between distance of parental pig breeds and heterozygosity of their $F_{1}$ crosses measured by genetic markers. Animal Genetics, 26: 135-140, 1995.

CIAMPOLINI, R; $\quad$ MOAZAMI-GOUDARZI, K.; VAIMAN, D.; DILLMANN, C.; MAZZANTI, E.; FOULLEY, J. L. LEVEZIEL, H.; CIANCI, D. Individual multilocus 
genotypes using microssatellite polymorphisms to permit the analyses of the genetic vaniability within and between Italian beef cattle breeds. Journal of Animal Science, 73: 3259-3268, 1995.

COUTINHO, L. L. \& REGITANO, L. C. A. O uso de marcadores moleculares na indústria animal.. In: CONGRESSO BRASILEIRO DE REPRODUÇÃO ANIMAL, 11, Belo Horizonte, 1995. Palestras apresentadas. Belo Horizonte: Colégio Brasileiro de Reprodução Animal, 1995. p.195-205.

CROW, J. F. \& KIMURA, M. An introduction to population genetics theory. Harper International Edition, New York, 1970. 591p.

DAVIS, S. L. Recent concepts in regulation of growth by GH and IGF. Journal of Animal Science, 66 (Sup. 3): 84-97, 1988.

DAVIS, S.K \& TAYLOR, J.F. Mechanisms of genetic control of beef carcass merit waits. Research project summary outline - Interim report. Texas A \& M University, 1995. 10p.

DEL LAMA, S. N. Caracterização genética das raças zebuínas criadas no Brasil através de polimorfismos proteicos e grupos sanguíneos. Ribeirão Preto, 1991. 207p. (Doutorado Faculdade de Medicina de Ribeirão Preto, Universidade de São Paulo).

DEL LAMA, S. N. \& ZAGO, M. A. Identification of the $\kappa$-casein and $\beta$-lactoglobulin genotypes in Brazilian Bos indicus and Bubalus bubalis populations. Brazilian Journal of genetics, 19: 73-77, 1996.

EIGEL, W. N.; BUTLER, J. E.; ERNSTROM, C. A. FARRELL Jr., H. M.; HARWALKAR, V. R.; JENNESS, R WHITNEY, R. M. Nomenclature of proteins of cow's milk: fifth revision. Journal of Dairy Science, 67: 1599 - 1631, 1984. 
EPSTEIN, H. \& MASON, I. L.. Cattle. In: MASON, I.L. (ed.) Evolution of domesticated animals. Longman, London, 1984. p. 6-27.

FERREIRA, M. E. \& GRATTAPAGLIA, D. Introdução ao uso de marcadores RAPD e RFLP em análise genética. EMBRAPA-CENARGEN, Brasília, 1995. 220p.

FALCONER, D. S. Introduction to quantitative genetics. 3 ed. Longman Scientific \& Technical, New York, 1989. 438p.

FREITAS, A. R. Comparação de métodos para estimação de componentes de variância e parâmetros afins de múltiplos caracteres em bovinos. Piracicaba, 1991. 170p. (Doutorado - Escola Superior de Agricultura 'Luiz de Queiroz", Universidade de São Paulo).

FRENCH, M. H.; JOHANSSON, I.; JOSHI, N. R; McLAUGHLIN, E. A. Razas europeas de ganado bovino. v.I. FAO: Estudios Agropecuarios, 67, Roma, 1968. p. 351-357.

GELDERMANN, H. Investigation on inheritance of quantitative characters in animals by gene markers. I. Methods. Theoretical and Applied Genetics, 46: 319-330, 1975.

GEORGES, M.; NIELSEN, D.; $\quad$ MACKINNON, M.; MISHRA, A.; OKIMOTO, R; PASQUINO, A.T.; SARGEANT,L.S.; SORENSEN, A; STEELE, M.R; ZHAO, X; WOMACK, J.E.; HOESCHELE, I.. Mapping quantitative trait loci controlling milk production in dairy cattle by exploiting progeny testing. Genetics, 139: 907-920, 1995.

GRODZICKER, T.; WILLIAMS, J.; SHARP, P.; SAMBROOK, J. Physical mapping of temperature - sensitive mutations of adenoviruses. Cold Spring Harbor Symposium on Quantitative Biology, 39: 439-446, 1974. 
GROENEN, M.A.M. \& POEL, J.J. Regulation of expression of milk protein genes: a review. Livestock Production Science, 38: 61-78, 1994.

HERD BOOK COLLARES. Introdução da raça Charolesa no Brasil, em particular no Rio Grande do Sul. A Hora Veterinária, 9: 20-26, 1982

HOLMES, N.G. Microsatellite markers and the analysis of genetic disease. British Veterinary Journal, 150: 411-421, 1994.

HUNTER, R.L. \& MARKET, C.L. Histochemical demonstration of enzymes separated by zone electrophoresis in starch gels. Science, 125: 1294 - 1295, 1957.

JEFFREYS, A.J.; WLSON, V. \& THEIN, S.L. Individual - specific "fingerprints" of human DNA. Nature, 316: 76, 1985.

JOBSE, C.; BUNTJER, J.B.; HAAGSMA, N.; BREUKELMAN, H.J.; BEINIEMA, J.J.; LENSTRA, J.A. Evolution and recombination of bovine DNA repeats. Journal of Molecular Evolutions, 41: 277-283, 1995.

KELLY, T.J. \& SMTH, H.O. A restriction enzyme from Haemophilus influenzae. П. Base sequence of the recognition site. Journal of Molecular Biology, 51: 393 - 409, 1970.

KEMENES, P. A. Quantificação das frequências dos alelos " $A$ " e " $B$ " dos genes de kappacaseina e $\beta$-lactoglobulina em algumas raças bovinas. Piracicaba, $1996.85 \mathrm{p}$. (Dissertação. Escola Superior de Agricultura "Luiz de Queiroz", Universidade de São Paulo).

KENNEDY, B.W.; GIBBINS, A.M.V.; GIBSON, J.P.; SMITH, C. Coalescence of molecular and quantitative genetics for livestock improvement. Journal of Dairy Science, 73: 2619-2627, 1990. 
KIRKPATRICK, B. W. Identification of a conserved microsatellite site in the porcine and bovine insulin-like growth factor-I gene 5' flank. Animal Genetics, 23; 543-548, 1992.

LANNELUC, R.D.; DRINKWATER, R.D.; ELSEN, J.M.; HETZEL,D.J.S.; NGUYEN, T.C.; PIPER, L.R.; THIMONIER, J. Genetic markers for the Boorola fecundity $(\mathrm{Fec})$ gene in sheep. Mammalian Genome, 5: 26-33, 1994.

LI, C.C. \& HORVITZ, D.G. Some methods of estimating the inbreeding coefficient. The American Journal of Human Genetics, 5: 107-117, 1953.

LIMA, F.P.. Os padrões raciais no zebu e o registro genealógico. In: CONGRESSO INTERNACIONAL DO ZEBU, 1., Uberaba, 1988. Anais. Campinas, Fundação Cargill, 1989. p.67-83.

LIEN, S.; GOMEZ-RAYA, L.; STEINE, T.; FIMLAND, E.; ROGNE, S. Associations between casein haplotypes and milk yield traits. Journal of Dairy Science, 78: 20472056, 1995.

LIN, C.Y.; SABOUR, M. P.; LEE, A J. Direct typing of milk proteins as an aid for genetic improvement of dairy bulls and cows: a review. Animal Breeding Abstracts, 60: 1-10, 1992.

LOFTUS, R. T.; McHUGH, D. E.; BRADLEY, D. G.; SHARP, P. M.; CUNNINGHAM, P. Evidence for two independent domestications of cattle. Proceedings of the National Academy of Science, U.S.A., 91: 2757-2761, 1994.

LUCY, M.H.; HAUSER, S.D.; EPPARD, P.J.; KRIVI, G.G.; COLLIER, R.J. Genetic polymorphism within the bovine somatotropin (bST) gene detected by polymerase chain reaction and endonuclease digestion. Journal of Dairy Science, 74 (Sup. 1): 284, 1991. 
MACHUGH, D.E.; LOFTUS, R.T.; BRADLEY, D.G.; SHARP, P.M.; CUNNINGHAM, P. Microsatellite DNA variation within and among European cattle breeds. Proceedings of the Royal Society of London. Series B, Biological Sciences, 256: 25-31, 1994.

MARZIALLI, A.S. \& NG-KWAI-HANG, K.F. Relationships between milk protein polymorfisms and cheese yielding capacity. Journal of Dairy Science, 69: 1193, 1986.

MASSEY, J.M. \& GEORGES, M. Genmark's approach to marker-assisted selection. Animal Bio-technology, 3: 95-109, 1992.

MEDRANO, J.F. \& AGUILAR-CORDOVA, E. Genotyping of bovine kappa-casein loci following DNA sequence amplification. Bio-Technology, 8: 144 - 146, 1990.

MIRANDA, G.; ANGLADE, P.; MAHÉ, M. F.; ERHARDT, G. Biochemical characterization of the bovine genetic $\kappa$-casein $\mathrm{C}$ and $\mathrm{E}$ variants. Animal Genetics, 24: 27-31, 1993.

MITTON, J.B. \& PIERCE, B.A. The distribution of individual heterozygosity in natural populations. Genetics, 95: 1043-1054, 1980.

MITRA A.; SCHLEE, P.; BALAKRISHNAN, C.R.; PIRCHNER, F. Polymorphisms at growth-hormone and prolactin loci in Indian cattle and buffalo. Joumal of Animal Breeding and Genetics, 112: 71-74, 1995.

MOODY, D.E.; POMP, D.; NEWMAN, S.; McNEIL, M.D.. Characterization of DNA polymorphisms and their association with growth and matemal traits in line 1 Hereford cattle. In: WORLD CONGRESS ON GENETICS APPLIED TO LIVESTOCK PRODUCTION, 5. Guelph, Canadá, Agosto de 1994. Proceedings, Guelph: Organizing Committee, 1994. v. 21. p. 221-224. 
MOORE, S.S.; BYRNE, K.; BERGER, K.T.; BARENDSE, W.; McCARTHY, F.; WOMACK, J.E.; HETZEL, D.J.S. Characterization of 65 bovine microsatellites. Mammalian Genome, 5: 84-90, 1994.

MULLIS, K. B.. The unusual origen of the polymerase chain reaction. Scientific American, 262: 36 - 42, 1990.

NEI, M. Genetic distance between populations. America Naturalist, 106; 283-292, 1972.

NEI, M. Estimation of average heterozigosity and genetic distance from a small number of individuals. Genetics, 89: 583-590, 1978.

NEI, M. Molecular evolutionary genetics. Columbia University Press, New York, 1987. $512 \mathrm{p}$.

NG-KWAI-HANG, K.F.; HAYES, J.F.; MOXIEY, J.E.; MONARDES, H.G. Association of genetic variants of casein and milk serum proteins with milk, fat and protein production by dairy cattle. Journal of Dairy Science, 67: 835-840, 1984.

NOTT, C.F.G. \& ROLLINS, W.. Effect of the $m h$ gene for muscular hypertrophy on birth weight and growth to one year of age in beef cattle. Growth, 43: 221, 1979.

NOWACK, R. M. \& PARADISO, J. L. Walker's mammals of the world. John's Hopkins University Press (Baltimore), 1983. v.2, p.1232-1255.

PACKER, I. U. Análise genética do crescimento até a desmama de bezerros Canchim. Piracicaba, 1977. 173p. (Livre-Docência - Escola Superior de Agricultura "Luiz de Queiróz", Universidade de São Paulo). 
PELOSO, J. V. A síndrome do stress do suíno (PSS) e a consequente formação da carne pálida, mole e exsudativa (PSE): uma visão geral. A Hora Veterinária, 80: 58-63, 1994.

PINHEIRO, L.E.L. Considerações sobre a constituição cromossômica do gado zebu. Informe Agropecuário, 10: 69-71, 1984.

QUAAS, R.L. Computing the diagonal elements and inverse of a large numerator relationship matrix. Biometrics, 32: 949-953, 1976.

RANDO, A.; DiGREGORIO, P.; MASINA, P.. Identification of bovine $\kappa$-casein genotypes at the DNA level. Animal Genetics, 19: 51-54, 1988.

RENDEL, J. Studies of blood groups and protein variants as a means of revealing similarities and differences between animal populations. Animal Breeding Abstracts, 35: 371-383, 1967.

ROCHA, J. L.; BAKER J. F.; WOMACK, J. E.; SANDERS, J. O.; TAYLOR, J. F. Statistical associations between restriction fragment length polymorphisms and quantitative traits in beef cattle. Journal of Animal Science, 70: 3360-3370, 1992.

RON, M.; BAND, M.; YANAI, A.; WELLER J. I. Mapping quantitative trait loci with DNA microsatellites in a commercial dairy cattle population. Animal Genetics, 25; 259-264, $1994 b$.

RON, M.; YOFFE, O.; EZRA, E.; MEDRANO, J.F.; WELLER, J.I. Detemination of effects of milk protein genotype on production of Israeli Holstein. Journal of Dairy Sciences, 77: 1106 - 1113, 1994a. 
ROSA, A.J.M.; REGITANO, L.C.A.; MERZEL, M.; PACKER, I.U.; RAZOOK, A.G.; COUTINHO, L.L. Polymorphism of growth hormone, microsatellite IGF-I and association with feedlot performance in Nelore cattle. In: CONGRESSO BRASILEIRO DE GENÉTICA, 42., Caxambú, 1996. Anais. p.298.

ROSA, A.N.; SILVA, L.O.C.; NOBRE, P.R.C.; MARIANIE, A.S.; FIGUEIREDO, G.R. Resultados gerais do controle de desenvolvimento ponderal das raças zebuínas. Informe Agropecuário, 10: 17-28, 1984.

ROUSE, J.E. World cattle. v. 1. Norman, University of Oklahoma Press, 1972. 485 p.

SAIKI, R.K.; SCHARF,S.; FALOONA, F.; MULLIS, K. B.; HORN, G. T.; ERLICH, H. A.; ARNHEIN, N. Enzymatic amplification of $\beta$-globin genomic sequences and restriction site analysis for diagnosis of Sickle Cell Anemia. Science, 230: 1350-1354, 1985.

SAIKI, R.K.; GELFAND, D.H.; STOFFE, S.J.; HIGUCHI, R; HORN, G.T.; MULLIS, K.B.; ERLICH, H.A. Primer-directed enzymatic amplification of DNA with a termostable DNA polymerase. Science, 239: 487, 1988.

SAMBROOK, J. FRITSCH, E.F. \& MANIATIS, T. Molecular Cloning: laboratory manual. 2.ed. Cold Spring Harbor, Cold Spring Harbor Laboratory, 1989.

SANTIAGO, A.A.. A expansão da raça Nelore. O Zebu no Brasil, 3: 34-44, 1972.

SANTIAGO, A.A. O Zebu na Índia, no Brasil e no mundo. Campinas, Instituto Campineiro de Ensino Agrícola, 1985. 744 p.

SCHLEE, P. ; GRAML, R; SCHALLENBERGER, E.; SCHAMS, D.; ROTTMANN, O.; OLBRICH-BLUDAU, A.; PIRCHNER, F. Growth hormone and insuline - like growth 
factor I concentrations in bulls of various growth hormone genotypes. Theoretical and Applied Genetics, 88: 497 - 500, 1994a.

SCHLEE, P.; GRAML, R; ROTTMANN, O.; PIRCHNER, F. Influence of growth hormone genotypes on breeding values of Simmental bulls. Journal of Animal Breeding and Genetics, 111: 253-256, 1994b. Resumo em CAB Abstracts on CD-ROM, 1996.

SCHELLANDER, K.; MAYR, B.; KALAT, M. Genomic analysis of kappa-casein genotypes in bulls. Journal of Animal Breeding and Genetics, 109: 311-315, 1992. Resumo em CAB Abstracts on CD-ROM, 1992.

SIMPSON, AJ.G. Mini Review. Microsatellite instability in human cancer. Brazilian Journal of Genetics, 19: 171-174, 1996.

SMITH, C. \& SIMPSON, S.P. The use of genetic polymorphisms in livestock improvement. Journal of Animal Breeding and Genetics, 103: 205, 1986.

SNEATH, P.H.A \& SOKAL, R.R. Numerical taxonomy. San Francisco, Freenan and Company, 1973. 573p.

SNEDECOR, G.W. \& COCHRAN, W.G. Statistical Methods. 6 ed.. Ames, The Iowa State University Press, 1967. 593 p.

SOLLER, M. Genetic mapping of the bovine genome using deoxyribonucleic acid-level markers to identify loci affecting quantitative traits of economic importance. Journal of Dairy Science, 73: 2628-2646, 1990.

SOUTHERN, E.M. Detection of specific sequences among DNA fragments separated by gel electrophoresis. Journal of Molecular Biology, London, 98: 503-517, 1975. 
SWOFFORD, D.L. \& SELANDER, R.B. Biosys-1. A computer program for the analysis of allelic variation in population genetics and biochemical systematics.. Release 1.7. Swofford, D.L., Ilinois Nat. Hist. Survey, 1989. 43 p.

STEEL, R.G.D. \& TORRIE, J.H. Principles and procedures of statistics. New York, Mac.Graw-Hill Book Company, 1960. 481p.

TANKSLEY, S. D. Mapping polygenes. Annual Review of Genetics, 27: 205-233, 1993.

TAUTZ, D. Hypervariability of simple sequences as a general source for polymorphic DNA markers. Nucleic Acids Research, 17: 6463-6471, 1989.

THEILMANN, J.L.; SKOW, L.C.; BAKER, J.F.; WOMACK, J.E. Restriction fragment lenght polymorphisms for growth hormone, prolactin, osteonectin, $\alpha$-crystallin, $\gamma$ crystallin, fibronectin and 21-steroid hydroxylase in cattle. Animal Genetics, 20:257266, 1989.

THODAY, J.M. Location of polygenes. Nature, 191: 368-370, 1961.

THREADGILL, D.W. \& WOMACK, J.E. Genomic analysis of the major bovine milk proteins. Nucleic Acids Research, 18: 6935 - 6942, 1990.

UNANIAN, M. M.; DeNISE, S. K.; ZHANG, H. M.; AX, RL. Rapid communication: Polymerase Chain Reaction - Restriction Fragment Length Polymorphism in the Bovine Growth Hormone Gene. Journal of Animal Science,72: 2203, 1994.

VAIMAN, D.; EGGEN, A.; MERCIER, D.; BAHRI-DARWICH, I.; GROHS, C.; BRUNEAU, D.; LAURENT, P.; CHAPUT, B.; OUSTRY, A.; FRELAT, G.; LEVÉZIEL, H.; CRIBIU, E.P. A genetic and physical map of bovine chromosome 3. Animal Genetics, 26: 21-25, 1995. 
VAN EENENNAAM, A. \& MEDRANO, J. F. Milk protein polymorphisms in California dairy cattle. Journal of Dairy Sciences, 74: 1730-1742, 1991.

VEIMALA, R.; VILKKI, J.; ELO, K.; MÄKI-TANILA, A. Casein haplotypes and their association with milk production traits in the Finnish Ayrshire cattle. Animal Genetics, 26: 419-425, 1995.

VIANNA, A.T.; GOMES, F.P. \& SANTIAGO, M. Formação do gado Canchim pelo cruzamento Charolês - Zebu. 2.ed. São Paulo, Nobel, 1978. 193p.

WEIR, B. S. Genetic data analysis: methods for dicrete population genetic data. 2.ed. , Massachusetts, Sinauer Associates, 1996. 445p.

WEIR, B. S. \& COCKERHAM, C. C. Estimating F-statistics for the analyses of population structure. Evolution, 38: 1358-1370, 1984.

WELLER, J.I.; KASHI, Y. \& SOLLER, M. Power of daughter and granddaughter designs for determining linkage between marker loci and quantitative trait loci in dairy cattle. Journal of Dairy Science, 73: 2525-2537, 1990.

WIGANS, G.R.; MISZTAL, I. \& VAN VLECK, L.D. Implementation of an animal model for genetic evaluation of dairy cattle in the Unites States. Journal of Dairy Science, 71 (Suppl.2): 54-69, 1988.

WOMACK, J. E. \& MOLL, Y. D. Gene map of the cow: conservation of linkage with mouse and man. The Journal of Heredity, 77: 2-7, 1986.

WOYCHIK, R. P.; CAMPER, S. A.; LYONS, R.H.; HOROWITZ, S.; GOODWIN, E.C.; ROTTMAN, F.M. Cloning and nucleotide sequencing of the bovine growth hormone gene. Nucleic Acids Research, 10: 7197-7210, 1982. 
WRIGHT, S. The interpretation of population structure by F-statistics with special regard to systems of mating. Evolution, 65: 395-420, 1965.

ZADWORNY, D. \& KUHNLEIN, U.. The identification of the kappa-casein genotype in Holstein dairy cattle using the polymerase chain reaction. Theoretical and Applied Genetics, 80: 631-634, 1990.

ZEUNER, F.E. \& MOURANT, A.E. Summary of the symposium. In: Man and cattle. Mourant, R.E. \& Zeuner, F.E. (eds.). London, Royal Anthropological Institute of Great Britain and Ireland, 1963. p. 158 - 166. 